\title{
Gaining Consensus on Implementation, Sustainability, and Benefits of School Garden Programming in Washington, D.C.
}

\author{
Hannah J Kipfer
}

Follow this and additional works at: https://researchrepository.wvu.edu/etd

\section{Recommended Citation}

Kipfer, Hannah J, "Gaining Consensus on Implementation, Sustainability, and Benefits of School Garden Programming in Washington, D.C." (2018). Graduate Theses, Dissertations, and Problem Reports. 7290. https://researchrepository.wvu.edu/etd/7290

This Dissertation is protected by copyright and/or related rights. It has been brought to you by the The Research Repository @ WVU with permission from the rights-holder(s). You are free to use this Dissertation in any way that is permitted by the copyright and related rights legislation that applies to your use. For other uses you must obtain permission from the rights-holder(s) directly, unless additional rights are indicated by a Creative Commons license in the record and/ or on the work itself. This Dissertation has been accepted for inclusion in WVU Graduate Theses, Dissertations, and Problem Reports collection by an authorized administrator of The Research Repository @ WVU.

For more information, please contact researchrepository@mail.wvu.edu. 
Gaining Consensus on Implementation, Sustainability, and Benefits of School Garden Programming in Washington, D.C.

\title{
Hannah J. Kipfer, M.S.
}

\author{
Dissertation submitted \\ to the College of Physical Activity and Sport Sciences \\ at West Virginia University \\ in partial fulfillment of the requirements for the degree of \\ Doctorate of Philosophy in \\ Kinesiology
}
Eloise Elliott, Ph.D., Chair
Sean M. Bulger, Ed.D.
Emily M. Jones, Ph.D.
James Rye, Ph.D.
Nancy M. Wells, Ph.D.

Department of Coaching and Teaching Studies

\author{
Morgantown, West Virginia \\ 2018
}

Keywords: School garden programming, Washington, D.C., sustainability, implementation, benefits, expert consensus

Copyright 2018 Hannah Kipfer 


\section{ABSTRACT \\ Gaining Consensus on the Start-Up, Sustainability, and Benefits of School Garden Programming in Washington, D.C.}

\section{Hannah Joy Kipfer}

Background/Purpose: Transforming school grounds into learning landscapes has gained unprecedented interest over the last 20 years and is primarily driven by the potential impact on the individual student, the family and school environments, and their surrounding communities. After passing landmark legislation and other health-focused initiatives (Healthy Schools Act, 2010), Washington, DC schools have experienced growing success with garden programming. DC's adoption of this act established a formal school garden program where currently 130 out of $233(56 \%)$ schools have implemented a variety of programming. As the interest in school gardening grows, it is necessary to evaluate programs such as those in Washington, DC and examine the perceived critical factors and compare the results to the current literature. The purpose of this study was to examine the components of successful school garden start-up, key recommendations for program sustainability, and perceived benefits and impact of garden programming in Washington, DC. Methods: A total of 30 participants comprised of classroom teachers and school administrators, community partners, non-profit organization directors and staff, and garden coordinators participated in a 3-round Delphi Method followed by three minifocus groups and one interview were employed to explore school garden expert opinions regarding successful start-up, sustainability, and perceived benefits of school garden programming. Results: The results of this study indicate that there are particular factors that increase the chances of successful start-up and sustainability of school garden programs. The Delphi results supported by the focus groups indicated four inherent and interconnected themes for the success and sustainability of a school garden program including (a) resources, including funding, materials, and curriculum; (b) buy-in from all stakeholders; (c) education, including tying the garden to the school goals as well as providing training for teachers; and (d) support, specifically from a garden coordinator. The results indicated in both the Delphi and focus groups that there are three inherent interconnected themes regarding the potential benefits of a school garden program including (a) education/cooperative learning, (b) student self-worth, motivation, and community engagement, and (c) health and wellness.

Conclusions: There is no universal model of school garden programming that can be applied to every community, but each community must design a plan that addresses the needs of their learners and educators. Although this study will not produce a recipe or blueprint for creating a certain type of school garden program, the hope is that the results of this study will energize and motivate practitioners and policymakers to make these programs a priority. The practices, ideas, and strategies being used in Washington, DC can also make a significant contribution to school garden programming, especially in low socio-economic communities. Future research should include further investigations of school garden programming globally and to initiate an exchange of ideas and resources that can strengthen the practice in all settings. 


\section{Dedication}

This is dedicated to the original Victory Garden soldier in my life. Thank you for the inspiration. Miss you and love you, Pap Pap.

This is also dedicated to my ever-so-patient family. I would not be here without your unconditional love and support. 


\section{Acknowledgments}

I can truly say that I never thought this moment would happen. Perhaps unbeknownst to her, Dr. Eloise Elliott provided the initial spark for this wild and crazy journey. I felt lost during my first year in graduate school until I heard Dr. Elliott speak in one of my classes. Thank you for your kindness, patience, and encouragement over the last few years. You truly are my hero and inspiration.

I have so many people in my life to be thankful for, and I wouldn't be on this path without the support and unconditional love from my family and friends. To my parents who have supported my emotionally, mentally, and financially over the past few years, I am forever grateful for the experiences in this life you have afforded me. To my brothers, thank you for helping me celebrate being a Mountaineer! You three make my heart smile. To my friends in CPASS, thank you for helping me stay sane over the last few years. Memories of chicken ball, hungry-hungry hippos, and long walks on the track will forever be in my heart. I look forward to all of the future professional conferences with you crazy kids!

To my dissertation committee, thank you for supporting me throughout this process and believing in my "not-so-PE" topic! I cherish the fact that I was able to learn from such a diverse group of professionals. Thank you for your guidance and encouragement.

Lastly, to my other half and adventure buddy. I wouldn't have survived this process without you by my side. Thank you for always being willing to "talk shop" and bring joy to my life! 


\section{Table of Contents}

INTRODUCTION

Statement of the Problem 3

Purpose of Study

Research Objectives

Definition of Terms

METHOD

Delphi Participants $\quad 6$

$\begin{array}{ll}\text { Study Design } & 8\end{array}$

$\begin{array}{ll}\text { Instrumentation } & 8\end{array}$

Data Collection Procedures $\quad 9$

Demographic survey 10

Round one 11

Round two 11

Round three $\quad 12$

Interview and mini focus groups $\quad 12$

Trustworthiness 13

Anonymity 13

$\begin{array}{ll}\text { Data Analysis } & 14\end{array}$

Round one $\quad 14$

Round two 15

Round three $\quad 15$

Interview and mini focus groups $\quad 15$

$\begin{array}{ll}\text { Triangulation } & 16\end{array}$

$\begin{array}{ll}\text { RESULTS } & 17\end{array}$

Interview and Mini Focus Group Participants 17

$\begin{array}{ll}\text { Successful School Garden Start-up } & 18\end{array}$

Infrastructure and resources 18

$\begin{array}{ll}\text { Interest and buy-in } & 19\end{array}$

Education and school curriculum 19

Personnel 19

School Garden Sustainability 20

Planning, training, and education for teachers 20

Interest and buy-in from school personnel and students 20

Materials and maintenance 21

Hired garden personnel 21

$\begin{array}{ll}\text { Potential Benefits } & 21\end{array}$

Teamwork, school curriculum, and diverse learners $\quad 21$

Student self-worth, motivation, and community 22

engagement

Student nutrition awareness and mental health 22 
Interview and Mini Focus Groups Results 23

Participant characteristics 23

Perceptions of results 24

Successful school garden start-up $\quad 27$

Sustainability of school garden programs 27

Perceived benefits 28

Future directions $\quad 30$

$\begin{array}{ll}\text { DISCUSSION } & 31\end{array}$

Implications for Practice $\quad 33$

Resources for schools $\quad 33$

Buy-in from stakeholders $\quad 35$

Education and training for teachers $\quad 36$

Support from garden coordinator $\quad 38$

$\begin{array}{ll}\text { Potential Benefits for Youth } & 39\end{array}$

The diverse learner 39

Student self-worth and motivation $\quad 39$

Pride of place $\quad 40$

Student health and wellness $\quad 40$

Future Directions and Considerations $\quad 41$

Limitations of the Study $\quad 42$

Conclusion 43

REFERENCES 45

$\begin{array}{ll}\text { APPENDICES } & 70\end{array}$

A. Extended Literature Review $\quad 70$

B. Research Methodology Flowchart 115

C. Invitation and Consent Email to Participants with Demographic 116

D. Demographic Survey 118

E. Instructions and Link to Round One Survey Email 120

\begin{tabular}{ll} 
F. & 122 \\
\hline & Round One Survey
\end{tabular}

G. Round One 5-Stage Thematic Analysis 123

H. Round Two Survey 130

I. $\quad$ Round Three Survey 135

J. Semi-Structured Mini-Focus Groups and Interview Guide 142

K. Thematic Coding for Round 1 Question 1 Statements 143

L. Thematic Coding for Round 1 Question 2 Statements 147

M. $\quad$ Round 1 Question 1 synthesized statements 151

N. Round 1 Question 2 synthesized statements 152

O. Sample data from interviews, successful school garden start-up $\quad 153$

P. Sample data from interviews, sustainability of school garden 155

Q. $\quad$ Sample data from interviews, perceived benefits 157

R. Interview and mini focus group participant and school information 159 


\section{LIST OF TABLES}

Table

Page

1. Demographic Survey Results with Inclusion Criteria 56

2. Participant Demographic Information 57

3. Number of Collected Responses and Consolidated Statements from 58 Each Round of Delphi

4. Final Items Meeting Consensus Criteria for Rounds 2 and $3 \quad 59$ of the Delphi

5. Research Objective One Delphi and Interview results: 61 School Garden Startup

6. Research objective Two Delphi and Interview Results: 63 School Garden Sustainability

7. Research Objective Three Delphi and Interview Results: 65 School Garden Benefits

8. Interview and Focus Group Results: Research Objective, Themes, and 67 Subthemes 


\section{LIST OF FIGURES}

Figure Page

1. Design and procedures of this 3-round Delphi study and follow-up 68 qualitative analysis.

2. Graphical Representation of the Delphi Results by Concepts and Themes 69 


\section{Introduction}

School gardens are not a new concept and can be historically traced throughout the world dating back to the 1600 s. In the early 1900 s, school gardens were encouraged by the United States (U.S.) Federal government primarily to help increase the food supply during times of war (Trelstad, 1997; Hayden-Smith, 2007; Kohlstedt, 2008). Today, there are approximately 7,101 school gardens across the U.S (United States Department of Agriculture [USDA], 2015). Although the primary use and size of the gardens vary, the typical school garden is utilized as an educational tool that promotes a multidisciplinary curriculum and a variety of experiential learning opportunities or to address health-related issues (Desmond, Grieshop, \& Subramaniam, 2002; Ozer, 2007; Blair, 2009). With thirty percent of American youth under the age of 20 suffering from obesity and other major health-related diseases, the school garden has been legitimized as a school-based intervention that may address these concerns (Wechsler, Devereaux, Davis, \& Collins, 2000; Center for Disease Control [CDC], 2011; Berezowitz et al., 2015). Numerous studies found that when used effectively, the garden may enhance youths' health and wellness, learning and academic achievement, connection with nature and environmental stewardship, personal, social and moral development, and vocational and life skills (Lineberger \& Zajicek, 2000; Graham \& Zidenberg-Cherr, 2005; Block, Gibbs, Staiger, Gold, Johnson, Macfarlane, Long, \& Townsend, 2012; Christian, Evans, Nykjaer, Hancock, \& Cade, 2014; Wells, Myers, \& Henderson, 2014; Berezowitz, Bontrager Yoder, \& Schoeller, 2015; Schreinemachers, Bhattarai, Subedi, Acharya, Chen, Yang, \& Mecozzi, 2017; Wells, Meyers, Todd, Henderson, Barale, Gaolach, \& Hendrix 2018). "In contrast to lessons where students are made to sit quietly, the utilization of the garden provides hands-on, real-life examples and kinesthetic experiences that can enrich the learning" and well-being of all students 
(Glenn, 2000; Corson, 2003; Bell \& Dyment, 2008; Rye, Selmer, Pennington, Vanhorn, Fox, \& Kane, 2012, p. 59).

Federal policy has been reactive to the research exhibiting the impact of school gardens (Dillon, Rickinson, Teamey, Morris, Choi, Sanders, \& Benefield, 2006). After passing landmark legislation and other health-focused initiatives (Healthy Schools Act, 2010), Washington, DC schools experienced growing success with garden programming and embraced the initiative to improve the health and wellness of their students, schools, and communities. Higgins (2016) stated that the school garden programming in DC has become "a beacon to other cities" for health-focused initiatives (Higgins, 2016, p.1). The Healthy School Act (2010) provides a guideline for all schools in the district to create a healthy place for all students. Schools are also required to document improvement and report annually on the results of the school garden (The Office of the Superintendent of Education (OSSE), 2016). According to DC's 2016 Healthy Schools Act School Garden Annual Report, there are currently a total of 130 schools (out of 233) with active gardens - an increase of 54 percent since the school year, 2011-2012 (OSSE, 2016). During the 2015 school year in DC, over 5,491 students received 3,040 hours of garden-based instruction, 315 teachers used the garden to teach 1,130 lessons, and 17 garden-based organizations provided support (OSSE, 2016). Unlike many school garden programs in the nation, over 55 percent of DC schools have designated school garden coordinators. According to Miller (2010) of the Earth Day Network, DC's school garden programming displays "some of the most seminal leadership on healthy schools in the country" (Fiegl, 2010, p. 1).

Validating and reenergizing this healthy schools movement, former First Lady Michelle Obama invited local public schools to grow vegetables at the White House Kitchen Garden in 2009 (Williams \& Dixon, 2013). With American children's health as the signature focus, Obama 
inspired initiatives (Let's Move, and Healthy, Hunger-Free Kids Act of 2010) providing schools with solutions that empower families and communities to strive toward making healthier decisions (Levi, Segal, St Laurent, Lang \& Rayburn, 2012).

\section{Statement of the Problem}

Despite the support of policies, government agencies, funding, etc., school gardens across the US are still exposed to issues that may impact the success and longevity of the program. In many instances, newly established school garden programs struggle with a multitude of problems including how to effectively implement the garden into the school as well as how to successfully sustain the program. Often, these issues could be avoided by learning from established and successful programming. Although school gardens can provide the educational foundation of experiential learning and healthy living, the use and impact of the garden is not fully understood (Fisher-Maltese, 2014; Ratasky, Shroder-Moreno, Jayaratne, Bradley, Grossman, \& Orr, 2015).

\section{Purpose of Study}

The purpose of this study was to gain consensus from selected school garden program stakeholders in Washington, DC. Each school garden in DC is unique and the stakeholders involved have varied experiences, interest, and motivation in the processes of the garden and the integration into the school goals and curriculum. Considering the unique characteristics and the significant amount of support available to programs in DC, selected stakeholders provided insight on best practices for garden implementation and sustainability strategies, as well as potential beneficial outcomes that may stem from garden implementation. The evaluation of these concepts provide insight for future school garden programs across the nation, emphasize the support and effort needed to establish such a program, and may initiate dialogue among 
school garden leaders (Ozer, 2007; Ratasky et al., 2015; DC Healthy Schools, 2016; OSSE, 2016).

\section{Research Objectives}

The purpose of this study was to gain consensus among school garden experts on three research objectives regarding school garden programming in Washington, DC:

1. To identify key recommendations for starting a school garden program.

2. To identify key components of a sustainable school garden program.

3. To identify perceived beneficial outcomes of the school garden.

With the goal of reaching expert consensus, a Delphi Method and follow-up focus groups deemed best for establishing steps towards stability and maturity for programs throughout the nation.

\section{Definition of Terms}

For this study, the following terms were defined as:

School garden: The cultivated areas around or near schools, tended at least partly by students (The Food and Agriculture Organization, 2010). For purposes of this research, this definition is expanded to include the use of growing plants as an educational strategy and learning tool in an educational setting and growing plants indoors or outdoors in a variety of ways that differ with every learner's circumstances.

School garden expert: An individual with advanced knowledge and experience in research, teaching, and application of school garden programming. Includes all participants in this study consisting of classroom teachers, school administrators, community partners, nonprofit organization directors and staff, and garden coordinators. 
Garden coordinators: An individual who provides at least one of the following: support to school staff in developing and implementing school garden programming; collaborates with teachers to develop in-class garden lessons that connect to grade-level curriculum and standards; teaches after-school garden clubs; helps organize community events; helps recruit, supervise and train volunteers; and documents outcomes and impacts through evaluation and tracking. 


\section{Method}

The Delphi method attempts to "overcome the weaknesses implicit in relying on a single expert, a one-shot group average, or a round-table discussion" by using a series of questionnaires and analysis techniques, interspersed with opinion feedback to reach a consensus of opinion (Ziglio, 1996, p.3; Clayton, 1997, p. 374; McInturff, 2009). Founded on the thought that "two heads are better than one", the Delphi method is designed as a group communication process aimed to examine and enhance the understanding of problems, opportunities, and solutions of knowledgeable individuals when there is incomplete knowledge about a problem or phenomenon (Dalkey, 1972, p.15; Okoli \& Pawloski, 2004; Bulger \& Housner, 2007; Skulmoski, Hartman, \& Krahn, 2007).

Qualitative interviews and focus groups have been characterized as useful in following the Delphi method to assist in investigating participant responses further and to uncover complex experiences and decision-making processes (Okoli and Pawlowski, 2004; Broom, 2005). Interviews and focus groups are particularly useful in gaining more robust descriptions of central themes at both a factual and meaning level (Kvale, 1996; McNamara, 1999).

\section{Delphi Participants}

Choosing the appropriate subjects for a Delphi study is considered to be the most essential step in the process due to it directly relating to the quality of results generated (Judd, 1972; Taylor \& Judd, 1989; Jacobs, 1996). Rather than randomly selecting panel members as is common in survey research, the sampling for Delphi studies is what Hasson, Keeney, and McKenna (2000) describe as purposive - the researcher chooses experts based on knowledge about the population and the participants' ability to best answer the research question. For this study, experts were defined as individuals involved in the conception and design, organization, 
instruction, or assessment of Washington, DC's school garden programs (OSSE, 2016). Panel members were heterogeneous in that each represented diverse and multiple views due to their different roles in garden programming (Ammon, 2009). The expert panel was comprised of K-12 classroom teachers and school administrators, community partners, and garden coordinators. All panel members associated with at least one school garden program in DC.

Although there is not a standard for a minimum panel size, Delphi studies with fewer than 10 participants are rarely conducted (Hader, 2009; Nworie, 2011; Okoli \& Pawlowski, 2004), however studies consisting of a sample as small as five panelists exist (Malone, Abarca, Hansten, Grizzle, Armstrong, Van Bergen, Duncan-Edgar, Solomon, \& Lipton, 2005). Fink and Kosecoff (1985) found that once the number of participants exceeded thirty, few new ideas are generated. Overall, an important factor of the initial panel size is determined by participant attrition, in that it must be large enough so that any reduction in response rates does not affect the quality of the data (Häder, 2009). For this study, a group of 30 experts was selected and recruited using three larger lists of online publically-available bibliographic information of potential participants based on the following criteria:

1. Classroom teachers $(n=10)$ were employed as a K-12 teacher in Washington, DC and were listed on the Office of the State Superintendent's Active School Garden list.

2. School Administration $(n=5)$ were employed as a K-12 administrator in Washington, DC and were listed on the Office of the State Superintendent's Active School Garden list.

3. Community partners $(n=10)$ were employed as staff or director at a non-profit or government organization in Washington, DC and were listed on the Office of the State Superintendent's Recommended School Garden Service Provider' listserv.

4. Garden coordinators $(n=5)$ were employed at least halftime by a K-12 school in Washington, DC and were listed on the Office of the State Superintendent's Recommended School Garden Service Provider' listserv or the 2017 School Garden Summit Attendees list.

\section{Study Design}


A three-round Delphi method was employed to examine the perspectives and opinions on the implementation, sustainability and benefits of school garden programming. The first round of questioning, the panel members were asked to answer two open-ended questions concerning the implementation and sustainability of school gardens programs. The following two rounds of questioning required the panel members to rate two lists of statements regarding their theoretical importance for current and future school garden programs. For this study, theoretical importance referred to the value of the rated item to the direct or indirect achievement of the intended outcomes (Ozer, 2007). During the third round, the panel members were also asked to rate a third list of items concerning the benefits of school garden programming and were asked to provide up to three additional benefits.

Okoli and Pawlowski (2004) suggested that Delphi participants tend to be open to followup interviews. Following the suggestions of Kennedy (2004), this study design included followup mini-focus groups and an interview to provide descriptive insights into the Delphi study's findings. Krueger (1994) has endorsed the use of small focus groups, for what is termed "minifocus groups" (p. 17), which can include 3-4 participants, when participants have specialized knowledge and experiences to discuss in the group (see Appendix B).

\section{Instrumentation}

The instrument for this study was derived from a thorough literature review (see Appendix A) relating to school garden programming and the recommendations for future research (Desmond, Grishop, \& Subramaniam, 2002; Ozer, 2007; Blair, 2009; Ohly et al., 2016; Turner et al., 2016). A draft of three questions derived from the literature review was reviewed by a group of researchers, including three teacher educators, one environmental psychologist, and one science educator, to ensure construct validity. The group of researchers was asked to 
evaluate the questions for content validity and completeness. The resulting instrument contained the three research objectives for this study regarding the implementation, sustainability, and benefits of school garden programming.

\section{Data Collection Procedures}

After this study was granted human research ethics committee approval by West Virginia University Institutional Review Board (IRB), prospective panel members were identified and sent the initial invitation letter that defined the study instructions and procedures, participant qualifications, the statement of informed consent, and a link to the demographic survey (see Appendix C and D). Participants accessed all four surveys via Qualtrics and were required to enter their email for identification to access each phase of the study. The three initial lists of prospective panel members included the contacts for organization directors and community partners $(n=35)$ and classroom teachers and administration $(n=127)$. To ensure a high response rate, the researcher took on an active, motivating role to keep the participants engaged in the study and maintained communication via phone calls, text messaging, and emails (Ludwig, 1994). Invited participants who were unwilling to participate or did not complete the demographic survey were excluded from the study and the researcher selected another prospective panel member from one of the three larger lists. This process continued until a total of 30 participants completed the demographic survey.

Fink and Kosecoff (1985) found that once the number of participants exceeded thirty, few new ideas are generated. As with other types of survey research, participant motivation and attrition can be problematic in multiple round Delphi studies and could discount the results of the study (Bulger, 2004; Sandrey \& Bulger, 2008). Assuming that some participants would not complete the entire study, an attrition rate of 30 percent ( 9 out of 30 participants) was 
established. Specifically, the results of the study would have been considered compromised if 70 percent response rate (21 out of 30 participants) was not achieved in all three rounds of the Delphi (Jacobs, 1996; Sumsion, 1999; Ross, Metcalf, Bulger, \& Housner, 2014). At the completion of this study, 24 of the 30 consenting participants completed the entirety of the Delphi for a response rate of 80 percent, meeting attrition criteria, so participant attrition was not considered to be a negative factor. The researcher was also committed to incorporate member checking and debriefing by having each participant review the data collected and the researchers' interpretation of the data following each round of data collection.

Demographic survey. At the beginning of the study, participants were sent an email containing the instructions for completing the entire study, the description and procedures of the Delphi, and a timeline for completion. During the demographic survey, panel members responded to five, close-ended questions (see Appendix D) asking them to provide their email and age-range, their working title associated with school garden programming, the Ward(s) in which they work in, and their experiences with school garden programming (see Table 1). The district is divided into eight wards, each with approximately 75,000 residents (The Council of the District of Columbia, 2018). The list of experiences participants were asked to identify with included the following areas: (a) recruit and support volunteers; (b) facilitate professional development workshops; (c) attend at least 2 school garden training workshops; (d) evaluate programs and create reports; (e) developed learning materials (curriculum, lesson plans, etc.); (f) instruct garden lesson for school-aged children; (g) coordinate student and/or parent engagement events; (h) provide support to classroom teachers; (i) participate in school garden committee; (j) and maintain the garden. Panel members were given two weeks to respond to and complete the demographic survey. If participants had not responded to the survey within one week, a follow- 
up email and text reminder was sent to encourage participation and reiterate the importance of their input.

Round one. After participant identification was finalized through the demographic survey, each particpant was sent the invitation email containing the instructions and the hyperlink to the Round One (R1) questionnaire (see Appendix E and F). During R1, panel members answered two open-ended questions about their recommendations for starting and sustaining school garden programming. Participants were given the opportunity to provide up to three responses, no more than 50-words, for each open-ended question. Panel members were given two weeks to complete the R1 questionnaire and those who had not completed after one week were sent a follow-up email and a text reminder to reiterate the importance of their participation. At the end of the allotted two weeks, the completed R1 questionnaire responses were collected and downloaded to a Microsoft Word document where each item was thematically analyzed to synthesize the group of statements (see Appendix G).

Round two. At the beginning of Round Two (R2), each participant was emailed feedback and results from R1 and instructions and the hyperlink to the R2 questionnaire (see Appendices H). During R2, each participant was provided with feedback in the form of synthesized statements from each question in R1 and rated the importance of each statement using Vagias' (2006) 5-point Likert scale: 5=extremely important, 4=very important, $3=$ moderately important, $2=$ slightly important, $1=$ not at all important. Panel members were given two weeks to complete the R2 questionnaire and those who had not completed after one week were sent a follow-up email and a text reminder to reiterate the importance of their participation. Upon the completion of R2, panel member's responses were collected and 
downloaded to an Excel file, and the individual and group mean scores were calculated for each item as well as the percentage of response for each item.

Round three. For the final round of the Delphi, Round Three (R3) each participant was emailed feedback in the form of individual and group mean ratings and percentage of responses for each item in R2. This gave participants an opportunity to visualize how their ratings compared to the overall group ratings for each item. During R3, participants were asked to reexamine and re-rate the final list of competencies, while considering the group and individual scores from R2. An additional question was added to the R3 survey asking the participants to rate a list of 'benefits' emergent in school garden literature. Participants were also given the opportunity to recommend up to three additional benefits that were not mentioned in the provided list (see Appendix I). R3 utilized the same procedures as R2 for questionnaire distribution and collection, participant feedback, and data collection and analysis.

Interview and mini focus groups. To further enhance the results of the 3-round Delphi investigation, semi-structured interviews and mini-focus groups were employed following the Delphi. Before the qualitative portion of the study, participants were emailed the results of the Delphi as well as instructions and details concerning the interviews and focus groups. A semistructured interview guide was developed by the researcher and two senior researchers at West Virginia University (WVU) and was informed by the results of the Delphi study and aligned to answer this study's research objectives (see Appendix J). The interview guide was pilot-tested with two physical education teacher educators and two graduate students at WVU before data collection and was modified for item clarity.

Interviews were conducted and audio-recorded via Zoom, a virtual platform, and each interview/focus-group lasted approximately one hour in length. Each interview/focus group 
audio was saved to a secure computer and transcribed, coded using NVivo 9 qualitative data processing software and were thematically analyzed. Interviews from each participant group were coded separately to identify key areas of correspondence and the difference between the groups. As part of the verification process, participants were provided with the transcriptions of their interview.

Trustworthiness. To maintain the credibility and trustworthiness of the participants' responses, the researcher developed early familiarity with the culture of the participants before the first data collection. The researcher visited the schools and organizations to gain an adequate understanding and to establish a relationship of trust. Participants were encouraged to be honest when contributing their opinions and were given opportunities to refuse participation. This ensured that only those who were genuinely willing to participate in the study offered honest opinions.

Trustworthiness of the data was ensured through member checking and peer checking of codes and theme development throughout the data analysis process. Lincoln and Guba (1985) referred to member checks as "the most crucial technique for establishing credibility" (p. 314). "Good research at the non-alienating end of the spectrum...goes back to the subject with the tentative results, and refines them in the light of the subjects' reactions" (Reason and Rowan, 1981, p. 248).

Anonymity. To avoid bias and maintain anonymity, participants were de-identified and were assigned an individual and unique code allowing only the researcher to access their details and use for re-identification. All identification information (name, contact information, demographics) were kept confidential and were not shared with other participants. Demographic and employment data were collected before beginning Round One to confirm the location of the 
panel member's place of work and to confirm they met the inclusion criteria. An advantage to using the Delphi method is that participants remain anonymous to the other panelists, which can prevent dominance by influential individuals, avoid group pressure, and illicit truthful responses (Sharkey \& Sharples, 2001). Participant anonymity also helped encourage openness in their opinions, which may have contributed to broader coverage of the topic.

\section{Data Analysis}

Responses from the panel members were used to create a list of items regarding the start-up and sustainability of school garden programming deemed as important and pertinent for current and future programs. Panel members were also asked to rate a list of benefits of the school garden as well as recommend other benefits not listed. Lastly, panel members were given the opportunity to participate in focus groups to discuss the results of the Delphi as well as to provide experiences and perceptions relating to the results.

Round one. R1 questionnaire responses were downloaded to a Microsoft Word document where each item was thematically analyzed using the following 5-stage analysis: (1) familiarize with the data by reading and re-reading through the list of statements; (2) open code to identify key issues, concepts, and themes by which the data could be referenced to identify a thematic framework; (3) develop a working analytical framework by involving all researchers and comparing labels and grouping codes into categories that are clearly defined (see Appendix G); (4) apply the analytical framework by indexing the data using the existing categories and codes; (5) chart the data by rearranging and organizing into the themes where related and like statements are synthesized and reduced to a singular statement (Pope et al., 2000). Two researchers, including the lead researcher and one senior researcher at WVU, analyzed and interpreted the data in $\mathrm{R} 1$ to preserve the nuance of the initial responses, maintain rigor, and 
reliability of analysis (Burnard, 1991; Sekayi \& Kennedy, 2017). The 5-stage analysis produced two lists of synthesized statements about the (1) start-up and the (2) sustainability of school garden programming.

Round two. R2 questionnaire responses were downloaded to an Excel file and the following was calculated for each statement: (a) percent totals of response rates, (b) percent totals for each level agreement for each statement to address the varying response rate; and (c) the individual and group mean ratings for each (Jacobs, 1996). For an item to be considered as important, it needed to receive a group mean rating of 4 or higher with at least 22 of the 30-panel members $(75 \%)$ rating as 4 or higher. Any item not meeting this criterion was considered to be noncritical and was rerated in R3.

Round three. The third and final round included the final rankings of the competencies re-rated in R2 as well as a third question for participants to rate and provide additional perceived benefits of the school garden. Responses from R3 were downloaded to an Excel file and the following was calculated for each statement: (a) percent totals of response rates, (b) percent totals for each level agreement for each statement to address the varying response rate; and (c) the individual and group mean ratings for each (Jacobs, 1996). For an item to be included in the final results of the Delphi study, it had to meet the final consensus criterion of a group mean score of 4 or higher (very important) with at least 75 percent of the rating of the panel. Any item that failed to meet these criteria were considered noncritical and were excluded from the final results. Final responses were organized by the research objectives and the developed themes.

Interview and mini focus groups. Each interview and mini focus group audio data was downloaded, transcribed and saved into a Microsoft Word document. Following Charmaz (2000) recommendations for interview and focus group analysis, a constant comparison method was 
employed by making systematic comparisons across each group with the aim to enrich the Delphi results and to better understand the participants' perspectives (Glaser and Strauss, 1967; Strauss, 1987; Glaser, 1992). Three major stages were used during the constant comparison analysis including (1) open coding the data from each focus group/interview into small units and attach a code to each unit, (2) axial coding by grouping the emergent codes into categories, and (3) selective coding by developing one or more themes that express the content of each of the groups (Glaser \& Strauss, 1967; Glaser, 1978, 1992; Strauss \& Corbin, 1998). To reduce researcher bias, the main researcher and a senior researcher analyzed the data independently. Final data were organized by the research objectives and the developed themes, allowing the researcher to easily view all data that spoke to each research question.

Triangulation. The results from the Delphi, focus groups, and interview was analyzed using a constant comparison method to develop core themes and a list of best practices for current and future school garden programs. To decrease potential researcher bias and to increase the validity, strength, and interpretive potential of this study, the researcher combined multiple data sources, investigators, methodological approaches, and data-analysis to form multiple triangulation (Denzin, 1970; Kimchi, Polivka, \& Stevenson, 1991). 


\section{Results}

The purpose of this study was to gain consensus on three research objectives regarding school garden programming in Washington, DC. The first objective was the identification of key recommendations for starting a school garden program. The second objective was the identification of key components of a sustainable school garden program. The third objective was the perceived beneficial outcomes of the school garden. Based on their knowledge and experience, expert panel members generated the results of these objectives through three rounds of inquiry as well as follow-up interviews and mini focus groups.

After the completion of the first round of the Delphi, 145 competencies were gathered from the panel members. The 5-stage thematic analysis synthesized the 145 competencies and created a list of 60 distilled statements (see Appendices K-N). The completion of the second round revealed 24 of the 60 items were rated as important and meeting the previously mentioned consensus criteria. Thirty-six statements did not meet consensus criteria $(\mu \leq 3.9)$ and were rerated in the third round. The completion of the third round revealed 33 items meeting consensus criteria and 27 statements not meeting consensus criteria that were excluded from the final results. Additionally, panel members were asked to respond to a third question in the third round of questioning. Panel members' added six statements to the third question, generating a final list of 49 competencies total for all three questions (see Table 3).

\section{Participants}

A total of 30 participants completed the preliminary demographic survey. Eighty percent $(n=24)$ were between the ages of 26 and 55 and identified under one of the following working titles: classroom teacher, school administrator, community partner/nonprofit director or staff, or garden coordinator. Each participant also selected three or more of the previously stated garden 
program work experiences (see Table 1). Each Ward in the district was represented and each particpant provided support to at least one school in DC (see Table 2). Table two also displays the total population of each Ward $(n=8)$ in the district, as well as the average yearly household income, number of schools, and the number of study participants representing each Ward (Ward Factsheet, 2017; Bureau of Labor Statistics, 2018; DC Health Matters, 2018).

\section{Successful School Garden Start-Up}

The first round of the Delphi study included two open-ended questions that were designed to solicit a broad range of responses regarding the start-up and sustainability of school gardens. Question one asked the participants to provide up to three recommendations for starting a successful school garden program. The panel members reached a level of agreement regarding 40.8 percent of the (20 of the final 49) statements were generated from Q1 and revealed the following four themes: (a) Infrastructure and Resources, (b) Interest and Buy-In, (c) Education, and (d) Support. For a full display of the final results for each question including the mean group rating for each response and the emergent themes, see Table 4.

Infrastructure and resources. Nine of the twenty statements comprising funding, space, and design, resources and materials encompassed this theme, representing $45 \%$ of the rated responses meeting consensus for Q1. Four of the eight statements referred to budget or funding to ensure a successful program (a) Ensuring stakeholders understand and are prepared to fund a multi-year investment, (b) Securing start-up funding for garden development, equipment, and materials, (c) Creating a budget in facilities operations to support maintenance of the different growing structures, and (d) Having an agreement with the school and all stakeholders on the size, initial cost, maintenance cost, and future plans of the garden. The other five statements referred to securing a manageable space and resources, having a plan for the 
space and resources, as well as ensuring access to all stakeholders (e) Starting with a manageable size, (f) Knowing where to find free resources and educational materials, (g) Having a plan for the available space, resources, and materials that are available, (h) Ensuring garden access to students, staff, and parents during school hours, and (i) Growing something students can harvest and eat as early as possible in the program.

Interest and buy-in. Five statements describe generating buy-in from multiple stakeholders' represented $25 \%$ of the rated responses meeting consensus for Q1. Three of the five statements referred to generating buy-in from stakeholders in the school community: (a) Buy-in from multiple stakeholders in the school community (teachers, students, school staff, and PTA), (b) Ensuring top-down buy-in from the school district and administration to build support, and (c) Securing a site with actively engaged participants and an enthusiastic team. The other two statements meeting consensus related to generating student enthusiasm which was one of the top-rated statements $(\mu=4.5)$ and celebrating achievements: (d) Generating student enthusiasm by connecting the garden with students' coursework, and (e) Celebrating garden program achievements often.

Education and school curriculum. Four statements describe how the school garden can be incorporated into education as well as the benefits from incorporating a garden curriculum represented $20 \%$ of the rated responses for Q1. Three of the four items were rated as the highest items ( $\mu=4.5$ ) in question one: (a) Creating clear goals and linking them to the schools goals, (b) Providing the students with an outdoor experience with hands-on activities in nature, and (c) Connecting the garden with program activities with content standards across the curriculum. One other highly rated statement was (d) educating students on food and nutrition as well as the importance of growing and eating local produce. 
Personnel. Two statements describe the support systems needed to start a successful school garden program, representing $6 \%$ of the rated responses meeting consensus for Q1. Both of these statements referred to the importance of having a point-person in charge of the garden and hiring a school garden coordinator: (a) Having a position designated for overall school garden management, and (b) Hiring a dedicated, knowledgeable skilled coordinator.

\section{School Garden Sustainability}

The final 13 statements for Q2 regarding the sustainability of school garden programming, generated the following four themes: (a) Planning, training, and education for teachers (b) Interest and buy-in from school personnel and students, (c) Materials and maintenance, and (d) Hired garden personnel.

Planning, training, and education for teachers. Four statements describe the importance of planning for a school garden and training teachers, representing $31 \%$ of the rated responses meeting consensus for Q2. All four statements refer to creating a relevant garden curriculum that is connected to the school goals and culture (a) To connect the priorities of the garden program to those of the school and school culture, (b) Having a yearlong instructional plan that is relevant and a part of the overall school curriculum, (c) Having a clear, easy to follow, standards-based curriculum, and (d) Providing training for teachers on how to incorporate the garden as an outdoor classroom. Panel members highly rated having a yearlong instructional plan that is relevant to the school at 4.4 out of 5. This statement was one of the three highest rated items in question two.

Interest and buy-in from school personnel and students. Four statements describe the need for commitment from different stakeholders to help maintain a sustainable school garden program represented $30.7 \%$ of the rated responses meeting consensus for Q2. Three of 
the four responses regarded the commitment from school staff and administration: (a) Buy-in and commitment from the school administration $(\mu=4.4)$, and (b) Buy-in and commitment from the teachers and staff, (c) Having an enthusiastic team, and (d) Involving all teachers in the garden. The statement regarding gaining commitment from the school administration was ranked as one of the top three rated items in question two. The fourth statement was ranked 4.6 out of 5 and was the highest rated item in question two. This statement referred to the importance of gaining student buy-in though ownership of the garden: Creating a sense of ownership with the students.

Materials and maintenance. Three statements describe the materials and design space for a sustainable school garden program, representing $23.1 \%$ of the rated responses for Q2. Two of the three statements refer to the organization and access to materials: (a) Ensuring that supplies and materials are well-organized and are based on the age group of the students, and (b) Having continual access to materials (seeds, plants, soil) to maintain the garden. The third statement suggests to disperse plantings throughout the school year: To design space and plantings so that growth occurs in phases throughout the school year to help decipher realistic yearly maintenance.

Hired garden personnel. Representing $13 \%$ of the rated responses for Q2, one statement describes the importance of hiring knowledgeable personnel to manage and maintain the garden: (a) Hiring a full-time, knowledgeable coordinator to manage and maintain the school garden program.

\section{Potential Benefits}

The final 16 statements regarding the potential benefits of the school garden (Q3), revealed the following three themes: (a) Teamwork, school curriculum, and diverse learners, (b) 
Student self-worth, motivation, and community engagement, and (c) Student Health and Wellness.

Teamwork, school curriculum, and diverse learners. Six statements describe potential benefits of school garden programming regarding student learning, school curriculum, and diverse learners. These six statements represent 37.5 percent of the responses for Q3. Two of the statements refer to student cooperative learning: (a) Encourages cooperative group learning and teamwork, and (b) Gives students opportunities to work together. Group learning and teamwork was the highest ranked statement in question three at a 4.6 out of 5.0. Two of the statements refer to the school curriculum and teaching: (c) Enhances school curriculum, and (d) Improves the quality of teaching. and the last two items refer to creating opportunities for learners with certain challenges: (e) Engages students particularly with learning disabilities or attention challenges, nd (f) In addition to all the obvious environmental literacy benefits, the garden provides a learning space where students who find sitting in a classroom a difficult place to shine.

\section{Student self-worth, motivation, and community and environmental commitment.}

Six statements describe the potential benefits regarding student ownership and enthusiasm, representing $37.5 \%$ of the responses for Q3. Four statements suggest that students may experience an increase sense of school pride, motivation, ownership, and self-worth: (a) Increases attachment, pride, and belonging to school, (b) Creates a sense of ownership, (c) Heightens student motivation and enthusiasm, and (d) Improves student sense of self. Student motivation and enthusiasm was rated as the second highest ranked statement in question three at a 4.5 out of 5.0. The two final statements in this category suggest that the school garden could increase commitment to the students' community and the environment: (e) Empowers students to change their community, and (f) Encourages conservation and ecological commitment. 
Student nutrition awareness and mental health. Four statements describe the potential health contributions to students, representing $25 \%$ of the responses for Q3. Three of the four statements suggest that the school garden has an impact on student diet: (a) Increases fruit and vegetable consumption, (b) Healthy way of eating, and (c) Students learn about how foods or produce is actually grown, the nutritional benefit adding vegetables as a part of one's overall diet, and most importantly learning lifelong skills that will benefit them personally. The final statement in the student health category refers to mental health: (d) Contributes to overall mental health of students.

\section{Interview and Mini Focus Groups Results}

Some studies have examined the role of Delphi, not as a standalone approach, but as a method that may be enhanced by other approaches (Rowe \& Wright, 2011). This phase of the study sought participant reflections and interpretations of the previous Delphi results as well as to seek explanations, ideas, and reflections on the research objectives. Findings from the mini focus groups and interview revealed five core ideas including (a) Perceptions of results, (b) Successful school garden start-up, (c) School garden sustainability, (d) Perceived benefits, and (e) Future directions. The results of this section will also identify emergent themes within each core idea as well as direct quotes to offer context and depth to the results (see Table 8).

Participant characteristics. All 30 Delphi panel members were invited to participate in follow-up mini focus groups. Participants identified under one of the roles for inclusion (classroom teacher, school administrator, community partner, or school garden coordinator) and each role was represented in this phase of the study. A total of 7-panel members volunteered to participate and were divided into three mini focus groups with two participants in each group $(n=6)$. The three mini focus groups ranged from 43 minutes to 60 minutes. Additionally, there 
was one individual hour-long phone interview $(n=1)$. Each participant had varied professional experiences and backgrounds relating to education and school garden programming. Table two describes the participants and their current roles, backgrounds and experiences with school gardens, the Ward their school garden is associated with, as well as their school information. Two of the participants worked with gardens across the district and did not have a designated school. Wards 3, 4, 5, and 8 were represented, providing a wide variety of school demographics (see Appendix R).

Perceptions of results. One of the main goals for the follow-up interview and focus groups was to explore in depth the panel members' perceptions of the Delphi study results. Two themes emerged from the qualitative data including the participants' areas of agreement and areas of concern with the Delphi results.

Areas of strong agreement. Analysis revealed two distinct concepts in which the participants strongly agreed with the Delphi study's identified critical competencies, including (a) buy-in and support from the school, and (b) student enthusiasm and curriculum integration. Buy-in. Participants agreed that stakeholder buy-in, specifically school buy-in was one of the highest priorities of a successful program. Two of the participants stated the importance of stakeholder buy-in and directly related buy-in to successful start-up of a program.

If they're excited, and they're ready to buy-in, then that means that they can have a school garden and it can take on a lot of different versions of what it means to have a school garden (G1, P1).

Student enthusiasm. Relating to buy-in, the second area of participant agreement was the rise in student enthusiasm from participating in the garden. Four participants discussed the importance of integrating the garden into the school goals and imbedding it within the curricular 
goals of the school. One school administrator discussed how student enthusiasm is extremely important at the start of the school garden.

So for us specifically, had the students not signed up for the elective, we would not have done it. We would still have a garden, but it wouldn't be at all integrated into our academic program. Connecting it with their coursework is great (G4, P6).

Another participant stated that from their experiences, the garden programs that don't incorporate the school day work and coursework with the garden would have a difficult time sustaining the program.

I think I was interested to see how the survey highlighted the importance of embedding this within the curricular goals and I think treating the garden as a resource that is important to incorporate within those already existing classes $(\mathrm{G} 2, \mathrm{P} 2)$.

Areas of concern. Although most participants agreed with the majority of the Delphi results, a few participants challenged the importance of a few concepts and provided support for their reasoning. Three main concepts emerged from the areas of concern including (a) support, (b) manageable size, (c) value, and (d) generalizability.

Support. The majority of participants $(n=5)$ thought that the statements in the Delphi referring to support, should have been rated higher regarding importance. One participant discussed the potential downfall of a program that does not have a strong support system.

There is so much burnout in a lot of programs where people are taking on too much on themselves and are not getting the support from the school that can sort of backfire $(\mathrm{G} 2$, P4).

One participant felt that the statement regarding hiring a dedicated, knowledgeable, and skilled coordinator should have been rated higher in the results due to their experience with inexperienced classroom teachers.

There's just not enough teachers feel comfortable in the garden and that's where that piece of like having someone who's dedicated to the garden space and can like different coordinate classrooms and you know facilitate that (G2, P4). 
Another participant pointed out that a program that is well-supported by the school financially may still not be successful because of a lack of curriculum integration.

It was interesting because I am in some ways a very well supported garden like, it's big, I get paid, I have a budget to buy, I have never run out of money to do what I wanted to do. But I would not say that our program is integrated, and so, at the same time, I'm like well, is this a successful school garden program? How do we determine what makes it successful? What is successful? A successful program could be the plant on the windowsill, and if the students were engaged and excited, then that is great. But I'm not sure that program would get funding or excitement from the administration (G1, P2).

Manageable size. One participant, who is the director of operations at her school, was surprised that 'manageable size' scored somewhat low due to the found success at their school with starting small and building as needed. No other participants discussed the lower rating of size and design of the garden.

Value. Four participants discussed the value and the perceptions of possible stakeholders and thought that this was an important item that was not discussed in the Delphi study. One participant stated feeling undervalued as a school garden coordinator due to the low priority and values of the stakeholders. This participant also suggested that stakeholders needed to put more value on money because the budget includes the salary that would pay the coordinator.

And I think that a lot of our school garden coordinators like we just love what we do so much that I think that this actually hurts us as being a professional is that we I think are underpaid and undervalued depending on going back to how much that school or the institution values us or values the garden $(\mathrm{G} 1, \mathrm{P} 2)$.

One participant felt that the emergent statements in the Delphi were important but were missing the value aspect.

The questions got away from the value-laden language, and it was more like the questions that I saw fitting best in this profile were ones like, getting support... and it goes back to how important do we think those values are (G1, P1).

Generalizable. Two participants found the statements challenging to rank not only

because of the importance of every item but because of the diversity and priorities of the 
programs in DC. One participant, in particular, felt strongly that every statement in the Delphi study should have been rated higher and promoted advocating for school garden programming in every school.

I felt like they're all very important, and it was hard to generalize for all of our programs this is what the priority is because I know some programs some things are more important and they like different priorities (G2, P3).

Successful school garden start-up. Three concepts emerged regarding successful school garden start-up including: (a) buy-in, (b) planning, and (c) support (see Table 5 and Appendix O). These concepts align with the results from the Delphi as well as other research findings regarding successful school garden implementation (Christian, Evans, Nykjaer, Hancock, \& Cade, 2014; Huys, De Cocker, De Craemer, Roesbeke, Cardon, \& De Lepeleere, 2017). Schools face multiple challenges in the implementation of garden programs, mainly related to limited resources of funding, personnel, and time (Ozer, 2007).

Buy-in. Two supporting concepts of buy-in as successful school garden start-up included gaining buy-in by (1) providing stakeholders proof of the positive impact of the garden and (2) gaining support from the school staff and administration.

Planning. Participants also described the importance of planning as part of a successful program and provided the following suggestions: (1) have a vision from the start regarding the design, (2) acquiring funding, and (3) embedding the garden into the school's curricular goals.

Support. Lastly, participants' supported the notion that a garden program's success relies heavily on (1) having a paid point-person in charge of the garden, (2) gaining support from policymakers, (3) school administration, and (4) creating partnerships with outside organizations.

Sustainability of school garden programs. Two emergent concepts regarding the sustainability of school garden programs included having goals that align with the school as well as 
having access to a strong support system (see Table 6 and Appendix P). School goals and support aligned with the results from the Delphi portion of this study as well as school garden research findings that successful, sustained programs attributed their success to widespread, long-term support of the principal, teachers, parents, and students (Ozer, 2007; Blair, 2009; Childs, 2011; Christian, 2014; Berezowitz, 2015).

School goals. In order for a school garden to be successful, program leaders need to ensure that the garden is a part of the (1) school culture and time and money are invested into empowering teachers to make the garden the core of the school's identity. There is an overwhelming amount of evidence proving that it is necessary to (2) intograte the garden into each grade level (Azuma et al., 2001).

Support. A reoccurring concept is the need for support in order for a program to survive. Participants' identified the following as imperative for successful sustainability: (1) garden coordinator, (2) teachers and administration, (3) parents and families, (4) partnerships, (5) values and commitment, and (6) funding, design, and maintenance.

Perceived benefits. Results found three emergent concepts referring to potential benefits of the garden including impact on (a) student learning, (b) school culture, and (c) health and wellness (see Table 7 and Appendix Q). These results align with the Delphi results as well as current school garden literature (Ozer, 2007; Blair, 2009; Childs, 2011; Christian, 2014; Berezowitz, 2015).

I think the benefits come out of whatever you are trying to do. But all of those resonate with me, and that's what's so amazing about school gardens. There are endless benefits $(\mathrm{G} 2, \mathrm{P} 3)$.

Student learning. The concept that participants found imperative was the gardens impact on student learning. "There are multiple indirect pathways by which school garden programs could affect students' general academic behavior and performance" (Ozer, 2007, p. 10). Six 
subthemes emerged from the student learning, including the impact on (1) academics, (2) student engagement, (3) student empowerment, (4) environmental awareness, and (5) students with challenges.

School culture. Two participants felt strongly about the importance of urban communities and lower socio-economic schools embracing gardens to bring awareness to the pride of place.

Participants in this study supported the notion of "pride of place" and described it as being an important concept of the school garden, especially in areas of low socioeconomic status. One participant discussed how the pride of place is a very high priority for them and for the school garden to be a place where students learn to take care of their community. Supported by anecdotal evidence, school garden research has described the potential effects on students' level of school pride and sense of belonging (DeMarco, Relf, \& McDaniel, 1999; Thorp \& Townsend, 2001; Blair, 2009). Specifically, the integration of gardening activities may facilitate student ownership, pride, a sense of belonging, and engagement within the learning environment (Block et al., 2012; Ozer, 2007). Consequently, children involved in gardening activities may view the school environment more positively, which may increase students' engagement (Swank, 2013).

I actually heard a student who is a $5^{\text {th }}$ grader at one of the planning meetings that we invite students to before we build the garden, he literally stood up in the meeting and said that the thing he was most excited about was that his school was finally going to have one of the nice things that some of the schools in the rich part of D.C had (G1, P1).

Wards 7 and 8 comprise the areas of the lowest income in DC, and one participant discussed the impact of the garden on schools in these Wards and the value of the administration places on the garden.

Because many find that their students don't experience that on a regular basis, sort of the community is just kind of like fragmented, there's just not a lot of space. Buildings are rundown buildings are vacant, there might be like litter in parks and things like that, and there's when that happens, they have this notion that I live in a community that's not worth taking care of $(\mathrm{G} 1, \mathrm{P} 1)$. 
Three participants discussed how the garden is empowering for the whole (2) school community and has the potential to shape eating habits as well as mindsets.

Health and wellness. Four participants discussed that gardening could contribute to creating (1) awareness of where food is coming from as well as having an impact on the students (2) long-term eating habits, resulting in an appreciation for healthy eating and a reduction in dietrelated illnesses. Two participants shared personal experiences of students changing their perception of food and being (3) willing and open to trying new and different foods. Four participants expressed the (4) social-emotional learning that students don't necessarily get in a classroom. One participant felt particularly strong about the social-emotional benefits and thought it to be more important than the impact on academics. Lastly, two participants discussed the benefit of students getting to (5) move and participated in physical activity during the school day.

Future directions. The majority $(n=5)$ of participants discussed the future directions of school garden programming with the idea that every school should have a garden. Two emergent concepts included the importance of (a) commitment from all stakeholders, and (b) advocating. One participant felt strongly about creating conversations and collaborating with stakeholders to create change. This participant also felt that people will suffer if change does not occur.

At some point, finally, every one of us will suffer. The schools which are incorporating gardening will suffer, the schools which are not incorporating gardening will suffer $(\mathrm{G} 3$, P5).

This participant discussed that this is a cultural issue and that stakeholders need to join together and make a change to the policymakers. It was also suggested to create a list of people resisting the movement, how people are resisting, how many ways people are accepting, and how many ways people are incorporating gardening into their school. 


\section{Discussion}

The review of literature discussed the critical competencies found in other studies to be necessary for successful school garden implementation and sustainability including: buy-in and long-term commitment from all stakeholders, availability of physical resources and funding, planning, teacher and faculty knowledge and preparation, curriculum integration, and garden maintenance (DeMarco, Relf, \& MCaniel, 1999; Ozer, 2007; Hazzard, Moreno, Beall, \& Zidenberg-Cherr, 2011). The review of literature also discussed multiple benefits of the school garden and how when used effectively, can improve children's health, education, and connection with nature and influence environmental stewardship, personal development, social and moral development, vocational skills, and life skills (Skelly \& Zajicek, 1998; Waliczek \& Zajicek, 1999; Glenn, 2000; Desmond, Grishop, \& Subramaniam, 2002; Corson, 2003; Graham \& Zidenberg-Cherr, 2005; Bell \& Dyment, 2008; Danks, 2010; Wells, Myers, \& Henderson, 2014; Berezowitz, Bontrager Yoder, \& Schoeller, 2015; Fisher-Maltese \& Zimmerman, 2015; Wells, Meyers, Todd, Henderson, Barale, Gaolach, Ferenz, Aitken, Tse, Pattison, Hendrix, Carson, Taylor, \& Franz, 2018).

There are over 130,000 schools across the US, and approximately only $18.5 \%$ school have adopted a garden program (USDA, 2015). Although several school districts have found success in creating, sustaining, and using a garden for academic instruction, the majority have not yet bought into the idea or are in search of practical models for implementing and sustaining a program. School gardens are not an easy undertaking and require motivation and long-term commitment. Much of the school garden literature has documented the numerous barriers that can impede such programming including: (a) fear and concern about young people's health and safety; (b) teachers confidence and expertise in teaching and learning outdoors; (c) the 
requirements of school curricula; (d) shortages of time, resources, and support; and (e) wider changes with the education sector and beyond. School garden research has reported that school gardens may be seen as 'add-ons' and 'in competition' with other extracurricular activities. Poor design, unsupportive administration, and weather conditions were also listed among the limitations (Azuma, Horan, \& Gottlieb, 2001; Barker, Slingsby, and Tilling, 2003; Rickinson, Dillon, Teamey, Morris, Choi, \& Sanders, 2004; Fisher-Maltese, 2013).

There is an increasing number of research studies attempting to evaluate the effectiveness of school gardening programs, mediation pathways, and implementation factors (Christian et al., 2014; Ohly et al., 2016). However, Williams and Dixon (2013) found a lack of rigor in school garden research including incomplete descriptions of methodological procedures, sampling techniques and validity and recommend more systematic and rigorous research using a type of experimental design. The research is limited by small samples with poor study designs and lack of adequate follow-up time (Blair, 2009; Robinson-O'Brien, Story, \& Heim, 2009; Christian et al., 2014). Currently, there has not been another study related to school gardens that have used this specific design requiring individuals representing multiple expert categories (teachers, administrators, coordinators, community partners) to work together to form a recommended blueprint for school garden start-up and sustainability.

A similar study was conducted with 10 California schools and was designed to define best practice models for implementing, sustaining, and using school gardens (Hazzard et al., 2011). Although Hazzard et al. had similar study objectives, there was a significant contrast in the study designs and sample size $(n=10)$. Regarding the difference in design, interviews were the sole method for data collection and were generated from nutrition education experts from the California Department of Education to identify the practices and environment of each school. 
Diversely, this study utilized a Delphi Method that allows for participants to self-generate competencies regarding successful school garden implementation and sustainability and then for the diverse group to come to a consensus on the critical competencies. To provide deeper meaning and explanation of the Delphi results, Delphi participants were recruited for follow-up interviews and focus groups. The addition of semi-structured focus groups and interviews with a subgroup of participants helped to provide strong examples of why some of the competencies that were critical in the final consensus were there, and also provided the researcher justification for adding back into the recommendations a few competencies that did not reach consensus. Results of this study could contribute to the development of a conceptual framework for studying important elements of starting and sustaining school garden programs, and also justify implementation.

\section{Implications for Practice}

The results of this study indicate that there are particular factors that increase the chances of successful start-up and sustainability of school garden programs. The results indicated in both the Delphi and focus groups that there are four inherent and interconnected themes for the success and sustainability of a school garden program including (a) infrastructure and resources; including funding, facilities, materials, space, and curriculum, (b) buy-in from all stakeholders, (c) education; including tying the garden to the school goals as well as providing training for teachers, and (d) support, specifically from a garden coordinator. The perceived potential benefits of the garden and the factors that lead to success were also identified.

Resources for schools. Many practical factors supporting school garden start-up and sustainability were rated highly important in the Delphi and were also prominent topics among the focus groups and interview participants. This theme represented the majority of the rated 
responses in the Delphi portion of the study. Securing start-up funding and ensuring continual investment from stakeholders were found to be the most important factors that affect school garden start-up and sustainability. Most school garden programs rely heavily on grants, parentteacher organization (PTO) budgets, and outside donations for funding. Unfortunately, most schools struggle with funding which is a necessary component for employing the garden to its fullest. Interestingly, some participants had varied views on the importance of budget and funding. Participants who voiced the high importance of budget were either classroom teachers or garden coordinators and viewed the budget as important for a full-time garden coordinator to provide teacher support. In contrast, two participants discussed how budget and funding are important but viewed stakeholder buy-in of higher importance. One participant, in particular, suggested that more value needed to be placed on gaining funding, particularly for a full-time garden coordinators position.

Findings from this study suggest that knowing where to find free resources and materials will help in reducing the costs of the garden program. Study participants reported different ways to gather free resources, materials, and donations through local community partners and organizations, school staff and volunteers, as well as the school's parent-teacher organization. Free garden curriculum resources are plentiful and easily accessible, and participants in the study highly recommended partnering with multiple organizations to help plan on organizing standards-based lesson plans and curricula aligned to the specific school goals and curriculum. Within the school system in the D.C. metropolitan area, there is no specific curriculum utilized within the schools. However, the school teachers or school garden leaders are free to choose the curricula that best fit the current teaching scenario and environment. The most frequently used curriculum in D.C. (OSSE approved) is the Food Corp curriculum, containing 35 lesson plans 
with activities to engage students in a fun and educational exploration of fruits, vegetables and healthy eating (Growing Minds, 2016).

DC is unique regarding available funding for garden programs. Schools within the District of Columbia Public Schools (DCPS) and public charter schools looking to establish or maintain a school garden may submit applications requesting up to $\$ 35,000$ for a two-year grant period (OSSE, 2017). There are obvious benefits to acquiring funding for school garden implementation. Research has articulated the importance of acquiring funding for a paid pointperson or coordinator that will help with providing a "well-coordinated and sustainable school garden program" (Ozer, 2007, p. 4). Although schools in DC have access to funding and support, some schools still struggle with finding enough funding to support a garden coordinator. Garden programs, particularly new ones, would be in jeopardy if funding declined or became nonexistent. To strengthen the school garden initiative with the thought that 'every school should have a garden,' funding strategies and policies adopted by the administration should be in place to support current and future projects.

Buy-in from stakeholders. The success of school garden implementation and sustainability rely heavily on the support and buy-in from all stakeholders including school administration, classroom teachers, school staff, students, parent volunteers/parents teacher organizations, community partners and organizations, and local government organizations. The results of the Delphi and interviews indicated that without ensuring top-down buy-in from all stakeholders in the school community, garden program implementation and sustainability would be difficult. Azuma et al. (2001) also found that schools with successful, sustained programs attributed their success to widespread, long-term support and buy-in from the principal, teachers, 
parents, and students. This study found that the perceptions and values of the administration are key to a successful program.

Another highly important area of agreement in the Delphi was gaining student enthusiasm for participating in the garden. Although this competency statement was rated high in the Delphi, only one participant discussed the importance of gaining student buy-in in the focus groups. This participant highlighted how gaining student buy-in at the start of the garden is extremely important as it enhances learning and gives students a chance to become active in their learning.

Another factor found to be critical for school garden success was securing a site with actively engaged participants and having an "enthusiastic team." Gaining and retaining buy-in can be difficult especially among teachers and school staff. Developing participation and commitment among teachers for the garden and an understanding of its potential as a learning resource is a long-term process (Beery et al., 2011). Teachers have busy schedules, standards to follow, and tests to administer, and generally, have other priorities other than the garden. This study found that if a school community has bought into the use of school gardens for education, the garden program will be more successful and the students will be more positive toward the use of gardens for learning.

Education and training for teachers. Involving all teachers in the garden and providing training for teachers on how to incorporate the garden were found to be critical in the Delphi results and supported by the interviews. Training for teachers is essential to ensure proper instruction of concepts and curriculum integration. Participants indicated that finding time for involving teachers and training them in the garden during the school day is difficult due to time constraints. One participant noted that the lack of scientific knowledge of the classroom teachers 
was a barrier to maintaining a successful program at their school. Azuma et al., (2001) reflected that the garden could be used for a broad range of lessons and that the garden will not last without outside help such as a garden coordinator, parent volunteers, community partners, etc.. The principal described that "when someone comes from the outside then they're (teachers) motivated" and sustaining the garden would probably not work unless you have "teachers with a passion" (p.286).

Creating clear goals with content standards across the curriculum and linking them to the priorities of the school and school culture was another condition for school garden success and sustainability. For a school gardening program to be truly effective, it must be tied to a comprehensive and cohesive educational plan or garden curriculum that is implemented across grade levels and ideally, tied to local, state or national education standards or needs (Desmond, 2004). Various aspects of the garden must connect to subjects that are already a part of the school's core subjects (Skanavis, 2009). Research has shown that school garden programs can be utilized as a vehicle for improving the health and well-being of youth and have the potential to go beyond strengthening the health behaviors of youth but to strengthen the entire school environment (Armstrong, 2000; Klemmer, Waliczek \& Zajicek, 2005; Ozer, 2007; Peterson \& Fox, 2007; Blair, 2009). However, before a school decides to implement a garden, a curriculum/curricula should be chosen and thoroughly reviewed by teachers, administration, and everyone involved with the garden implementation. Additionally, integration of the garden program into the whole school curriculum must be considered.

Interestingly, two participants suggested that the garden program should be incorporated into the school day as a 'specials' or extra class where a garden coordinator would act "as a resource to teachers" - similar to physical education, art, or library. The thought behind this type 
of school integration is easing the burden on classroom teachers. In contrast, although difficult and time-consuming, the majority of participants agreed that the garden needed to be fully integrated into the school curriculum and school goals and should not be treated as a specials class to achieve success and sustainability. The only hope for sustainability is to ensure widespread, long-term support of all parties involved and that it is an integral part of the curriculum at each grade level (Azuma, Horan, \& Gottlieb, 2001).

Support from garden coordinator. Having a paid coordinator to help assist with program goals and teacher comfortability is key to the success and sustainability and was rated as very important in the Delphi and described in the interviews. The interviews found that most school garden programs rely on one single coordinator or teacher to maintain the program, which can create a high-pressure situation for that individual. Most classroom teachers do not have the time to coordinate lessons in the garden nor do they have the time or desire to take on another responsibility.

Although most participants viewed having a paid position as important, one school administrator found success with a motivated and passionate "champion" that is not paid for maintaining the garden. This participant also noted that the program would most likely "die out" if this "champion" were to leave and they were left to find someone else who "cares deeply enough" to continue the program. Azuma et al. (2001) found that having a paid person to run the school garden program is the key to a sustainable program. Ozer (2007) discussed the importance of long-term commitment and effort of a garden leader or "champion" at each school site for garden sustainability. Programs without a garden leader or coordinator are vulnerable to failure.

\section{Potential Benefits for Youth}


The results in the Delphi and supported by the focus groups indicated that there are four inherent interconnected themes regarding the potential benefits of a school garden program including (a) education/cooperative learning, (b) Student self-worth, motivation, (c) community engagement, and (d) health and wellness.

The diverse learner. Both the Delphi results and interview results found the garden to be an important tool in creating a sense of ownership, and increasing attachment, pride, and belonging to their school. Over half of the statements in the Delphi indicated having an impact on student learning, school curriculum, and diverse learners, and the interview results echoed these factors.

One participant described her experiences with students with behavior issues and how the garden tends to be a calming, restful place for them. Regarding classroom behavior, researchers have found that exposure to natural settings is helpful in reducing attention deficit symptoms, and behavioral issues among children (Kuo \& Taylor, 2004; Taylor et al., 2001; Barros et al., 2009). Participants also discussed the importance of the garden for students "for whom tactile learning" is difficult. Some parents and teachers in the Stephanie Alexander Kitchen Garden Program study saw that experiential learning was particularly useful for boys and it effectively engaged "kids who don't shine in academia." One of the classroom teachers from the study was quoted saying: "the children that struggle with concepts of mathematics and weight and measurement respond far better to a hands-on approach" (Block et al., 2012, p.424).

Student self-worth and motivation. Five statements describe the potential benefits regarding student ownership and enthusiasm, representing $31.2 \%$ of the responses related to the benefits of the garden. Four statements suggest that students may experience an increased sense 
of school pride, motivation, ownership, and self-worth and student motivation and enthusiasm was rated as the second highest ranked statement in question three at a 4.5 out of 5.0.

Pride of place. Another factor rated highly in the Delphi and interviews was the impact that the school garden empowers students to change their community. Participants supported the notion of 'pride of place' and how students, especially in areas of low socioeconomic status, learn how to place a high value on their community. All participants agreed that students gain a strong sense of pride and ownership in their accomplishments in the school garden.

Student health and wellness. The Delphi results identified health and wellness factors on student diet and lifelong wellness as well as contributing to students overall mental health. Participants indicated in the interviews that students were more willing and open to try not only new foods but were open to new experiences. Bandura (1997) supported the concept that a school environment that is supportive of healthy food choices will strengthen students' perceived self-efficacy to eat more healthfully and is more likely to lead to effective behavior change. One participant stated that her students could "identify foods as one of the producible things" (G3, P5). The more recent research found that school gardens have the potential to affect fruit and vegetable availability in the home environment (Wells, et al., 2018). Participants in this study agreed that students who experience the garden are more willing to try new and different things and would potentially lead to long-term impacts.

Concerning health promotion among adolescents, school grounds merit consideration as a potential setting for intervention (Dyment \& Bell, 2007). School gardens can supply fresh produce, achieve hands-on education, and provide a source of physical activity (PA) (Wells, Myers, \& Henderson, 2014). While a healthy school environment is a recognized component of coordinated school health programs, school grounds and gardening are a growing strategy 
intended to influence children's eating and activity behaviors (Canadian Institute for Health Information, 2006; Bernstein, 2015). There are dramatic and important differences between the PA opportunities afforded by conventional and green school grounds. Time spent outdoors is a strong predictor of PA. However, there is a need for research explicitly examining the effects of school gardens on children's PA, using valid, objective measures of PA (Wells, Myers, \& Henderson, 2014).

\section{Future Directions and Considerations}

Globally, school communities are facing more pressure every year to increase student academic performance while aligning with federal and state legislation and are also faced with increasing childhood obesity interventions that include combating the problems of low fitness and excess obesity (Bottoms \& Schmidt-Davis, 2010; Lohman, 2010; Berezowitz, Yoder, \& Schoeller, 2015). With buy-in from stakeholders and community members, the school garden movement is becoming more energized and validated with educational implementation. School gardens can be used as an educational tool in the United States and around the world and have the capabilities of impacting many other aspects of life (Williams \& Dixon, 2013; Wansink, Hanks, \& Just, 2015).

Results are consistent with those of prior research in that for gardening to become part of a school curriculum, future research must provide evidence that gardens benefit students and that the benefit is worth the time and effort spent outside the classroom (Smith, 1999). Three participants of this study agreed that change needed to be made through policy and collaboration. It is suggested both by the participants in this study and Ohly, et al. (2016) to gain support from policymakers to create change, support expansion, and ongoing evaluation of school garden programs. To support the movement of 'every school should have a garden,' programs need to 
become institutionalized, supported by a set of policies that acknowledge the value of a school garden. Outcomes should be documented in ways that will affect educational policy toward school gardening and subsequent funding (Blair, 2009). Azuma, et al. (2001) recommend the following policy approaches: (a) the local Board of Education needs to adopt a formal policy and mission statement, (b) school training needs to be district-wide and linked to school curriculum, (c) collaborate with other environmental initiatives, (d) ensure the availability of a standardsbased garden curriculum to teachers, and (e) collaborate and partner with community-based organizations.

\section{Limitations of the Study}

This study focused solely on school garden programming in Washington, DC and selected participants that work in this geographical area and have diverse backgrounds and experiences in the school garden. School garden programs in DC are unique in that they have a vast support system including funding and partnerships. Participants also had to meet predetermined qualifications and inclusion criteria. This panel of experts is not a representative sample of school garden experts across the US. Although results of this study are difficult to generalize, the knowledge gained from this study may be useful to organizations and schools interested in school gardening projects and provide practical working knowledge of how school gardens are being implemented and sustained in Washington, DC schools.

Although the Delphi has numerous applications, the method has drawn some criticisms, including the time involved in accomplishing a study, especially with a large number of respondents (Huckfeldt \& Judd, 1974; Gordon \& Pease, 2006). The proposed sample size of this

study was 40 participants but was not met due to time obligations of the researcher. A total of 30 participants were recruited to participate in the study, and a total of 24 completed the entirety of 
the Delphi, meeting attrition criteria, so participant attrition was not considered to be a negative factor. To ensure a high response rate, the researcher took on an active, motivating role to keep the participants engaged in the study (Ludwig, 1994).

Conventionally, open-ended questions are common in the initial exploratory phase of the Delphi, which is then followed by quantitative or statistical surveys in the latter phases; this is where consensus is produced. This aspect has drawn criticism for its potential to force consensus and for not allowing participants to elaborate on their responses (Goodman, 1987; Hasson et al., 2000; Sackman, 1974). However, this study implemented a Hybrid Delphi technique that incorporated, in addition to the Delphi, follow-up, semi-structured focus groups and interviews (Landeta, Barrutia, \& Lertxundi, 2011). Focus groups present some limitations, and this study found difficulties in gathering groups together. The proposed set of focus groups was two groups of four experts. Due to participants' time and other arrangements, four mini-focus groups with one to two participants was utilized. However, combining the focus groups with the Delphi method assisted in the effective development of exerts opinions, were low cost, and encouraged learning through sharing information and opinions (Williams, White, Klem, Wilson, \& Bartholomew, 2006; Landeta et al., 2011).

\section{Conclusion}

There is no universal model of school garden programming that can be applied to every community, but each community must design a plan that addresses the needs of their learners and educators. The hope for the results of this study will energize and motivate practitioners and policymakers to make these programs a priority. The practices, ideas, and strategies being used in Washington, DC can also make a significant contribution to school garden programming, especially in low socio-economic communities. Future research should include further 
investigations of school garden programming globally and to initiate an exchange of ideas and resources that can strengthen the practice in all settings. 


\section{References}

Ammon, U. (2009). Delphi-Befragung. In Handbuch Methoden der Organisationsforschung (pp. 458-476). VS Verlag für Sozialwissenschaften.

Azuma, A., Horan, T., \& Gottlieb, R. (2001). A Place to Learn and a Place to Grow: School Gardens in the Los Angeles Unified School District, A Survey, Case Studies, and Policy Recommendations.

Bell, A. C., \& Dyment, J. E. (2008). Grounds for health: the intersection of green school grounds and health-promoting schools. Environmental Education Research, 14(1), 77-90.

Berezowitz, C. K., Bontrager Yoder, A. B., \& Schoeller, D. A. (2015). School gardens enhance academic performance and dietary outcomes in children. Journal of School Health, 85(8), 508-518.

Blair, D. (2009). The child in the garden: An evaluative review of the benefits of school gardening. The Journal of Environmental Education, 40(2), 15-38.

Block, K., Gibbs, L., Staiger, P. K., Gold, L., Johnson, B., Macfarlane, S., \& Townsend, M. (2012). Growing community: the impact of the Stephanie Alexander Kitchen Garden Program on the social and learning environment in primary schools. Health Education \& Behavior, 39(4), 419-432

Bohnert, A., Fredricks, J., \& Randall, E. (2010). Capturing unique dimensions of youth organized activity involvement: Theoretical and methodological considerations. Review of Educational Research, 80(4), 576-610.

Broom, A. (2005). Using qualitative interviews in CAM research: a guide to study design, data collection and data analysis. Complementary therapies in medicine, 13(1), 65-73. 
Bureau of Labor Statistics, U.S. Department of Labor, Occupational Outlook Handbook, OOH FAQ's on the internet at https://www.bls.gov/ooh/about/ooh-faqs.htm (visited January $15,2018)$.

Centers for Disease Control and Prevention, (2010). Nutrition and Physical Activity Program to Prevent Obesity and other Chronic Diseases. Obesity Among Low-Income Preschool Children. Centers for Disease Control and Prevention, Atlanta, GA

Centers for Disease Control and Prevention, (2011). School health guidelines to promote healthy eating and physical activity. MMWR. Atlanta GA, CD.C. \& US Department of Health and Human Services 60 (5).

Centers for Disease Control and Prevention, (2013). Comprehensive school physical activity programs: A guide for schools. US Department of Health and Human Services: Atlanta, GA.

Christian, M. S., Evans, C. E., Nykjaer, C., Hancock, N., \& Cade, J. E. (2014). Evaluation of the impact of a school gardening intervention on children's fruit and vegetable intake: a randomised controlled trial. International Journal of Behavioral Nutrition and Physical Activity, 11(1), 99.

Corson, C. (2003). Grounds for Learning. Learning By Design, 13.

Dalkey, N., \& Helmer, O. (1963). An experimental application of the Delphi method to the use of experts, Management Science, 9(3), 458-467.

Danks, S. G. (2010). Asphalt to ecosystems: Design ideas for schoolyard transformation. New Village Press.

Danks, S. G. (2014). Living schoolyards for California: Exciting new state resolution will bring more children outside at public schools. Children and Nature Network. 
D.C. Health Matters (2018). Measuring what matters in DC. Retrieved April 15, 2018, from http://www.dchealthmatters.org/.

DeMarco, L. W, Relf, D., \& McDaniel, A. (1999). Integrating gardening into the elementary school curriculum. Horticulture Technology, 9, 276-281.

Desmond, D., Grieshop, J., \& Subramaniam, A. (2002). Revisiting garden based learning in basic education: Philosophical roots, historical foundations, best practices and products, impacts, outcomes, and future directions. Food and Agriculture Organization, 59.

Desmond, D., Grieshop, J., \& Subramaniam, A. (2004). Revisiting garden-based learning in basic education. Food and Agriculture Organization of the United Nations.

Dillon, J., Rickinson, M., Teamey, K., Morris, M., Choi, M. Y., Sanders, D., \& Benefield, P. (2006). The value of outdoor learning: evidence from research in the UK and elsewhere. School science review, 87(320), 107.

Dirks, A. E., \& Orvis, K. (2005). An evaluation of the junior master gardener program in third grade classrooms. HortTechnology, 15, 443-447.

Douglass, Y.P., \& Habib, D. (2014). Seeds of Solidarity: Grow Food Everywhere ChilD.C.are Provider Garden Program 2014 Summary of Successes, Results from Research, and Outreach Outcomes.

Faddegon, P. A. (2005). The kids growing food school gardening program: Agricultural literacy and other educational outcomes. Cornell University.

Fisher-Maltese, C. (2014). The School Garden. Thinking Critically about Environments for Young Children: Bridging Theory and Practice, 89. 
Fisher-Maltese, C., \& Zimmerman, T. D. (2015). A Garden-Based Approach to Teaching Life Science Produces Shifts in Students' Attitudes toward the Environment. International Journal of Environmental and Science Education, 10(1), 51-66.

Glaser, B. G. \& Strauss, A. L. (1967). The Discovery of Grounded Theory: Strategies for Qualitative Research. Chicago: Aldine. Glaser, B. G. (1992). Emergence vs. Forcing. Basics of Grounded Theory Analysis. Mill Valley: Sociology Press.

Glenn, J. L. (2000). Environment-Based Education: Creating High Performance Schools and Students.

Goluchowicz, K., \& Blind, K. (2011). Identification of future fields of standardisation: An explorative application of the Delphi methodology. Technological Forecasting and Social Change, 78(9), 1526-1541.

Graham, H., \& Zidenberg-Cherr, S. (2005). California teachers perceive school gardens as an effective nutritional tool to promote healthful eating habits. Journal of the Academy of Nutrition and Dietetics, 105(11), 1797-1800

Gresenz, C. R., Blanchard, J. C., Timbie, J. W., Acosta, J., Pollack, C. E., Ruder, T., ... \& Hair, B. (2012). Behavioral health in the District of Columbia: assessing need and evaluating the public system of care. Rand health quarterly, 2(1).

Hayden-Smith, R. (2007). "Soldiers of the Soil": The work of the United States School Garden Army during World War I. Applied Environmental Education and Communication, 6(1), $19-29$.

Hasson, F., Keeney, S., \& McKenna, H. (2000). Research guidelines for the Delphi survey technique. Journal of advanced nursing, 32(4), 1008-1015. 
Huys, N., De Cocker, K., De Craemer, M., Roesbeke, M., Cardon, G., \& De Lepeleere, S. (2017). School Gardens: A Qualitative Study on Implementation Practices. International journal of environmental research and public health, 14(12), 1454.

Jacobi-Vessels, J. L. (2013). Discovering nature: The benefits of teaching outside of the classroom. Dimensions of Early Childhood, 41(3), 4-10.

Koch, S., Waliczek, T. M., \& Zajicek, J. M. (2006). The effect of a summer garden program on the nutritional knowledge, attitudes, and behaviors of children. HortTechnology, 16(4), 620-625.

Kohlstedt, S. G. (2008). "A better crop of boys and girls": The school gardening movement, 1890-1920. History of Education Quarterly, 48(1), 58-93.

Landeta, J., Barrutia, J., \& Lertxundi, A. (2011). Hybrid Delphi: A methodology to facilitate contribution from experts in professional contexts. Technological Forecasting and Social Change, 78(9), 1629-1641.

Leis, A.S., Whittington, M. B., \& Kleinhenz, M. (2011). Student farms at United States colleges and universities: Insights gained from a survey of the farm managers. NACTA Journal 55(1): 9-15.

Levi, J., Segal, L. M., St Laurent, R., Lang, A., \& Rayburn, J. (2012). F as in fat: how obesity threatens America’s future 2012.

Lieberman, G. A., \& Hoody, L. L. (1998). Closing the Achievement Gap: Using the Environment as an Integrating Context for Learning. Results of a Nationwide Study.

Lineberger, S. E., \& Zajicek, J. M. (2000). School gardens: Can a hands-on teaching tool affect students' attitudes and behaviors regarding fruit and vegetables? HortTechnology, 10(3), 593-597. 
Louv, R. (2008). Last child in the woods: Saving our children from nature-deficit disorder. Algonquin books.

McGinnis, J., \& Stefanich, G. (2007). Special needs and talents in science learning. In S. Abell \& N. Lederman (Eds.), Handbook of research on science education (pp. 537-559). New York, NY: Routledge.

National Research Council. (1996). National science education standards. Washington, DC: National Academy.

National Research Council. (2012). A framework for K-12 science education: Practices, crosscutting concepts, and core ideas. Washington DC: National Academy. Retrieved from http://books.nap. edu/catalog.php?record_id=13165.

Natural Learning Initiative. (2012). Benefits of connecting children with nature: Why naturalize outdoor learning environments. College of Design, North Carolina State University.

Office of the State Superintendent of Education [OSSE], (2018). School Garden Service Provider List, on the internet at https://osse.dc.gov/service/school-garden-serviceprovider-list (visited February 1, 2018).

Ogden, C. L., Carroll, M. D., Curtin, L. R., Lamb, M. M., \& Flegal, K. M. (2010). Prevalence of high body mass index in US children and adolescents, 2007-2008. Jama, 303(3), 242249.

Ohly, H., Gentry, S., Wigglesworth, R., Bethel, A., Lovell, R., \& Garside, R. (2016). A systematic review of the health and well-being impacts of school gardening: synthesis of quantitative and qualitative evidence. BMC Public Health, 16(1), 286. 
Ozer, E. J. (2007). The effects of school gardens on students and schools: Conceptualization and considerations for maximizing healthy development. Health Education \& Behavior, 34(6), 846-863.

Passy R, Morris M, Reed F. (2010). Impact of school gardening on learning: Final report submitted to the Royal Horticultural Society. London: RHS (National Foundation for Educational Research).

Plaka, V., \& Skanavis, C. (2016). The feasibility of school gardens as an educational approach in Greece: a survey of Greek schools. International Journal of Innovation and Sustainable Development, 10(2), 141-159.

Powell, C. (2003). The Delphi technique: myths and realities. Journal of advanced nursing, 41(4), 376-382.

Ray, R., Fisher, D. R., \& Fisher-Maltese, C. (2016). SCHOOL GARDENS IN THE CITY: Does Environmental Equity Help Close the Achievement Gap?. Du Bois Review: Social Science Research on Race, 13(2), 379-395.

REAL School Gardens. (2013). What we do. Retrieved from http://www.realschoolgardens.org/what-we-do.aspx

Resnick, M. D., Bearman, P. S., Blum, R. W., Bauman, K. E., Harris, K. M., Jones, J., et al. (1997). Protecting adolescents from harm: Findings from the National Longitudinal Study on Adolescent Health. Journal of the American Medical Association, 278(10), 823832.

Riggs, K. (2012). Strategies for Sustainability of Grant-funded Programs. 
Robinson-O'Brien, R., Story, M., \& Heim, S. (2009). Impact of garden-based youth nutrition intervention programs: a review. Journal of the American Dietetic Association, 109(2), 273-280.

Rowe, G., \& Wright, G. (2011). The Delphi technique: Past, present, and future prospectsIntroduction to the special issue. Technological Forecasting and Social Change, 78(9), $1487-1490$.

Rye, J., Selmer, S., Pennington, S., Vanhorn, L., Fox, S., \& Kane, S. (2012). Elementary School Garden Programs Enhance Science Education for All Learners. TEACHING Exceptional Children, 44(6), 58-65.

Savoie-Roskos, M. R., Wengreen, H., \& Durward, C. (2017). Increasing fruit and vegetable intake among children and youth through gardening-based interventions: A systematic review. Journal of the Academy of Nutrition and Dietetics, 117(2), 240-250.

Schreinemachers, P., Bhattarai, D. R., Subedi, G. D., Acharya, T. P., Chen, H. P., Yang, R. Y., ... \& Mecozzi, M. (2017). Impact of school gardens in Nepal: a cluster randomised controlled trial. Journal of Development Effectiveness, 9(3), 329-343.

Sherer, P. M. (2006). The Benefits of Parks. San Francisco, CA: The Trust for Public Land. Skanavis, C., \& Giannoulis, C. (2009). A training model for environmental educators and interpreters employed in Greek protected areas and ecotourism settings. International Journal of Sustainable Development \& World Ecology, 16(3), 164-176.

Smith, L. L., \& Motsenbocker, C. E. (2005). Impact of hands-on science through school gardening in Louisiana public elementary schools. HortTechnology, 15(3), 439-443.

Strauss, A. L. (1987). Qualitative Analysis for Social Scientists. Cambridge: Cambridge University Press. 
Strife, S., \& Downey, L. (2009). Childhood development and access to nature: A new direction for environmental inequality research. Organization \& environment, 22(1), 99-122.

The Office of the State Superintendent of Education, [OSSE]. (2017). OSSE School Garden Grant FAQ’s. Electronic Factsheet Available from: https://osse.dc.gov/sites/default/files/dc/sites/osse/page_content/attachments/201718\%20School\%20Garden\%20Grant\%20FAQ.pdf

Thorp, L., \& Townsend, C. (2001, December 12). Agricultural education in an elementary school: An ethnographic study of a school garden. Proceedings of the 28th Annual National Agricultural Education Research Conference in' New Orleans, LA (pp. 347$360)$.

Trelstad, B. (1997). Little machines in their gardens: a history of school gardens in America, 1891-1920. Landscape Journal, 16(2).

Turner, L., Sandoval, A., \& Chaloupka, F.J. (2014). School Garden Programs are on the Rise in U.S. Public Elementary Schools, but are Less Common in Schools with Economically Disadvantaged Student Populations. Chicago, IL: Bridging the Gap Program, Health Policy Center, Institute for Health Research and Policy, University of Illinois at Chicago.

Turner, L., Eliason, M., Sandoval, A., \& Chaloupka, F.J. (2016). Increasing prevalence of US elementary school gardens, but disparities reduce opportunities for disadvantaged students. Journal of School Health, 86(12), 906-912.

United States Department of Agriculture (2015). Farm to School Consensus. Retrieved from: https://farmtoschoolcensus.fns.usda.gov/ 
United States Department of Labor. Employment and Training Administration. Moving forward: Tips for program sustainability (2016). Electronic factsheet available from: http://www.doleta.gov/business/PDF/SustainTip s.pdf

Waliczek, T.M., \& Zajicek, J.M. (1999). School gardening: Improving environmental attitudes of children through hands-on learning. Journal of Environmental Horticulture, 17, 180184.

Waliczek, T. M., Lineberger, R. D., Zajicek, J. M., \& Bradley, J. C. (2000). Using a web-based survey to research the benefits of children gardening. HortTechnology, 10(1), 71-76.

Ward Factsheet. (2017, May 03). Retrieved March 5, 2018, from http://www.dcpcsb.org/wardfactsheet.

Wechsler, H., Devereaux, R. S., Davis, M., \& Collins, J. (2000). Using the school environment to promote physical activity and healthy eating. Preventive medicine, 31(2), S121-S137.

Wells, N. M., Myers, B. M., \& Henderson Jr, C. R. (2014). School gardens and physical activity: A randomized controlled trial of low-income elementary schools. Preventive Medicine, 69, S27-S33.

Wells, N. M., Meyers, B. M., Todd, L. E., Henderson, C. R., Barale, K., Gaolach, B., Ferenz, G., Aitken, M., Tse, C. C., Pattison, K. O., Hendrix, L., Carson, J. B., Taylor, C., \& Franz, N. K. (2018). The carry-over effects of school gardens on fruit and vegetable availability at home: A randomized controlled trial with low-income elementary schools. Preventive Medicine, 112, 152-224.

Williams, P. L., White, N., Klem, R., Wilson, S. E., \& Bartholomew, P. (2006). Clinical education and training: using the nominal group technique in research with radiographers to identify factors affecting quality and capacity. Radiography, 12(3), 215-224. 
Williams, D. R., \& Dixon, P. S. (2013). Impact of garden-based learning on academic outcomes in schools: Synthesis of research between 1990 and 2010. Review of Educational Research, 83(2), 211-235. 
Table 1

\section{Tables}

Demographic Survey Results with Inclusion Criteria

\begin{tabular}{lcc}
\hline & $n$ & $\%$ \\
\hline Inclusion Criteria & 15 & $57.7 \%$ \\
Recruit and support volunteers & 17 & $65.4 \%$ \\
Facilitate professional development workshops & 18 & $69.2 \%$ \\
Attend at least 2 school garden training workshops & 12 & $46.1 \%$ \\
Evaluate programs and create reports & 18 & $69.2 \%$ \\
Developed learning materials (curriculum, lesson plans, etc & 17 & $65.4 \%$ \\
Instruct garden lesson for school-aged children & 19 & $73.1 \%$ \\
Coordinate student and/or parent engagement events & 11 & $42.3 \%$ \\
Provide support to classroom teachers & 10 & $38.5 \%$ \\
Participate in school garden committee & 18 & $69.3 \%$ \\
Maintain the garden & 26 & $100 \%$ \\
Provide support to at least one school in DC & & \\
Participant Age Range & 1 & $3.3 \%$ \\
18-25 & 6 & $20 \%$ \\
26-35 & 9 & $30 \%$ \\
36-45 & 9 & $30 \%$ \\
$46-55$ & 4 & $13.3 \%$ \\
56-65 & 1 & $3.3 \%$ \\
66+ & & \\
Participant work title & 10 & $33.3 \%$ \\
Classroom teacher (PreK-12 & 5 & $16.7 \%$ \\
School administrator (PreK-12 ${ }^{\text {th }}$ grade) & 10 & $33.3 \%$ \\
Non-profit organizations director or staff/community partner & 5 & $16.7 \%$ \\
School garden coordinator & 5 \\
\hline
\end{tabular}

Note. $n=$ number of participants out of $30 . \%=$ percentage of respondent totals. 
Table 2

Participant Demographic Information

\begin{tabular}{|c|c|c|c|c|c|}
\hline Ward & $\begin{array}{l}\text { Total } \\
\text { Population }\end{array}$ & $\begin{array}{l}\text { Median Yearly } \\
\text { Income }\end{array}$ & Race & \# of Schools & $\begin{array}{l}\text { Study } \\
\text { Participants }\end{array}$ \\
\hline Ward 1 & 89,053 & $\$ 113,972$ & $\begin{array}{l}\text { 57.2\% White } \\
\text { 22.7\% African American } \\
5.9 \% \text { Asian } \\
\text { 14.2\% Some other race }\end{array}$ & $\begin{array}{l}11 \text { (DCPS) } \\
12 \text { (DCPC) }\end{array}$ & $\begin{array}{l}4 \text { of } 30 \\
(13.3 \%)\end{array}$ \\
\hline Ward 2 & 90,828 & $\$ 209,147$ & $\begin{array}{l}\text { 68.6\% White } \\
\text { 13.9\% African American } \\
\text { 8.9\% Asian } \\
\text { 8.6\% Some other race }\end{array}$ & $\begin{array}{l}8 \text { (DCPS) } \\
3 \text { (DCPC) }\end{array}$ & $\begin{array}{l}1 \text { of } 30 \\
(3.3 \%)\end{array}$ \\
\hline Ward 3 & 84,156 & $\$ 257,224$ & $\begin{array}{l}\text { 81.5\% White } \\
5.3 \% \text { African American } \\
\text { 7.5\% Asian } \\
5.7 \% \text { Some other race }\end{array}$ & 10 (DCPS) & $\begin{array}{l}3 \text { of } 30 \\
(10 \%)\end{array}$ \\
\hline Ward 4 & 86,461 & $\$ 123,353$ & $\begin{array}{l}\text { 29.4\% White } \\
\text { 49.2\% African American } \\
2.3 \% \text { Asian } \\
\text { 19.1\% Some other race }\end{array}$ & $\begin{array}{l}16 \text { (DCPS) } \\
23 \text { (DCPC) }\end{array}$ & $\begin{array}{l}6 \text { of } 30 \\
(20 \%)\end{array}$ \\
\hline Ward 5 & 86,608 & $\$ 82,425$ & $\begin{array}{l}\text { 28.7\% White } \\
58.9 \% \text { African American } \\
\text { 3.1\% Asian } \\
\text { 9.3\% Some other race }\end{array}$ & $\begin{array}{l}14 \text { (DCPS) } \\
33 \text { (DCPC) }\end{array}$ & $\begin{array}{l}8 \text { of } 30 \\
(26.7 \%)\end{array}$ \\
\hline Ward 6 & 94,530 & $\$ 140,853$ & $\begin{array}{l}\text { 47.6\% White } \\
\text { 41.4\% African American } \\
\text { 4.6\% Asian } \\
6.4 \% \text { Some other race }\end{array}$ & $\begin{array}{l}19 \text { (DCPS) } \\
17 \text { (DCPC) }\end{array}$ & $\begin{array}{l}4 \text { of } 30 \\
(13.3 \%)\end{array}$ \\
\hline Ward 7 & 80,642 & $\$ 56,759$ & $\begin{array}{l}\text { 2.7\% White } \\
\text { 92.6\% African American } \\
.3 \% \text { Asian } \\
\text { 4.4\% Some other race }\end{array}$ & $\begin{array}{l}18 \text { (DCPS) } \\
23(\mathrm{DCPC})\end{array}$ & $\begin{array}{l}4 \text { of } 30 \\
(13.3 \%)\end{array}$ \\
\hline Ward 8 & 79,846 & $\$ 45,239$ & $\begin{array}{l}\text { 4.1\% White } \\
\text { 92.2\% African American } \\
.4 \% \text { Asian } \\
3.3 \% \text { Some other race }\end{array}$ & $\begin{array}{l}19 \text { (DCPS) } \\
26 \text { (DCPC) }\end{array}$ & $\begin{array}{l}4 \text { of } 30 \\
(13.3 \%)\end{array}$ \\
\hline
\end{tabular}

Note. \# of Schools $=$ number of prekindergarten $-12^{\text {th }}$ grade public, private, and charter schools in DC. DCPS $=$ District of Columbia Public Schools. DCPC $=$ District of Columbia Public Charter Schools. Study participants = number of participants working in each Ward. 


\section{Table 3}

Number of Collected Responses and Consolidated Statements from Each Round of Delphi.

\begin{tabular}{|c|c|c|c|c|c|c|}
\hline \multirow[t]{3}{*}{ Round 1} & \multicolumn{3}{|c|}{ Collected responses } & \multicolumn{3}{|c|}{ Consolidated statements } \\
\hline & Q1 & & $\mathrm{Q} 2$ & Q1 & & Q2 \\
\hline & $\overline{73}$ & & 72 & $\overline{32}$ & & 28 \\
\hline \multirow[t]{3}{*}{ Round 2} & \multicolumn{3}{|c|}{$\begin{array}{l}\text { Statements meeting } \\
\text { consensus }(\mu>4)\end{array}$} & \multicolumn{3}{|c|}{$\begin{array}{l}\text { Statements not meeting } \\
\text { consensus }(\mu \leq 3.9)\end{array}$} \\
\hline & $\underline{\mathrm{Q} 1}$ & $\underline{\mathrm{Q} 2}$ & Q3 & Q1 & $\underline{\mathrm{Q} 2}$ & Q3 \\
\hline & $\overline{14}$ & $\overline{10}$ & $\overline{\mathrm{NA}}$ & $\overline{18}$ & $\overline{18}$ & $\overline{\mathrm{NA}}$ \\
\hline Round 3 & 6 & 3 & 10 & 12 & 15 & 5 \\
\hline Final Items & 20 & 13 & 21 & 12 & 15 & 5 \\
\hline
\end{tabular}


Table 4

Final Items Meeting Consensus Criteria for Rounds 2 and 3 of the Delphi.

\begin{tabular}{|c|c|c|c|}
\hline & \multirow{2}{*}{$\begin{array}{l}\text { Final statement and Question } \\
\text { Question 1: School Garden Start-up }\end{array}$} & \multicolumn{2}{|c|}{$M$} \\
\hline & & $\underline{R 2}$ & $\underline{R 3}$ \\
\hline 1 & $\begin{array}{l}\text { Ensuring top-down buy-in from the school district and administration to } \\
\text { build support. }\end{array}$ & $*$ & 4.1 \\
\hline 2 & Hiring a dedicated, knowledgeable skilled coordinator. & $*$ & 4 \\
\hline 3 & Having a position designated for overall school garden management. & $*$ & 4.1 \\
\hline 4 & $\begin{array}{l}\text { Buy-in from multiple stakeholders in the school community (teachers, } \\
\text { students, school staff, and PTA). }\end{array}$ & $*$ & 4.4 \\
\hline 5 & $\begin{array}{l}\text { Securing start-up funding for garden development, equipment, and } \\
\text { materials. }\end{array}$ & $*$ & 4.1 \\
\hline 6 & $\begin{array}{l}\text { Ensuring garden access to students, staff, and parents during school } \\
\text { hours. }\end{array}$ & $*$ & 4.1 \\
\hline 7 & $\begin{array}{l}\text { Generating student enthusiasm by connecting the garden with students' } \\
\text { coursework. }\end{array}$ & $*$ & 4.5 \\
\hline 8 & Celebrating garden program achievements often. & $*$ & 4.1 \\
\hline 9 & Knowing where to find free resources and educational materials. & $*$ & 4.1 \\
\hline 10 & $\begin{array}{l}\text { Having a plan for the available space, resources, and materials that are } \\
\text { available. }\end{array}$ & $*$ & 4 \\
\hline 11 & Starting with a manageable size. & $*$ & 4.2 \\
\hline 12 & $\begin{array}{l}\text { Educating the students on food and nutrition and the importance of } \\
\text { growing and eating local produce. }\end{array}$ & $*$ & 4.4 \\
\hline 13 & $\begin{array}{l}\text { Providing the students with an outdoor experience with hands-on } \\
\text { activities in nature. }\end{array}$ & $*$ & 4.5 \\
\hline 14 & $\begin{array}{l}\text { Connecting the garden with program activities with content standards } \\
\text { across the curriculum. }\end{array}$ & $*$ & 4.5 \\
\hline 15 & $\begin{array}{l}\text { Growing something students can harvest and eat as early as possible in } \\
\text { the program. }\end{array}$ & 3.9 & 4.0 \\
\hline 16 & $\begin{array}{l}\text { Securing a site with actively engaged participants and an enthusiastic } \\
\text { team. }\end{array}$ & 3.9 & 4.3 \\
\hline 17 & $\begin{array}{l}\text { Ensuring stakeholders understand are prepared to fund a multi-year } \\
\text { investment. }\end{array}$ & 3.9 & 4.2 \\
\hline 18 & $\begin{array}{l}\text { Creating a budget in facilities operations to support maintenance of the } \\
\text { different growing structures. }\end{array}$ & 3.6 & 4.0 \\
\hline 19 & $\begin{array}{l}\text { Having an agreement with the school and all stakeholders on the size, } \\
\text { initial cost, maintenance cost, and future plans of the garden. }\end{array}$ & 3.8 & 4.1 \\
\hline 20 & Creating clear goals and linking them to the schools goals & 3.9 & 4.5 \\
\hline & Question 2: School Garden Sustainability & & \\
\hline 1 & $\begin{array}{l}\text { Hiring a full-time, knowledgeable coordinator to manage and maintain } \\
\text { the school garden program. }\end{array}$ & $*$ & 4 \\
\hline 2 & Having an enthusiastic team. & $*$ & 4.2 \\
\hline 3 & Buy-in and commitment from the school administration. & $*$ & 4.4 \\
\hline
\end{tabular}


$4 \quad$ Buy-in and commitment from the teachers and staff. $\quad * \quad 4.3$

$5 \quad$ Creating a sense of ownership with the students. $\quad * \quad 4.6$

To connect the priorities of the garden program to those of the school and school culture.

Having a yearlong instructional plan that is relevant and a part of the overall school curriculum.

8 Having a clear, easy to follow, standards-based curriculum.

$3.8 \quad 4.1$

9 Involving all grades and teachers in the garden.

$* \quad 4.2$

Providing training for teachers on how to incorporate the garden as an outdoor classroom.

$* \quad 4.3$

11 Ensuring that supplies and materials are well-organized and are based on the age-group of the students.

Having continual access to materials (seeds, plants, soil) to maintain the garden.

To design space and plantings so that growth occurs in phases throughout the school year to help decipher realistic yearly maintenance.

Question 3: Perceived Benefits of School Garden

1 Increases fruit and vegetable consumption

NA 4.2

2 Healthy way of eating

A foundation in which students learn about how foods or produce is

NA NA actually grown, the nutritional benefit adding vegetables as a part of one's overall diet, and most importantly learning lifelong skills that will benefit

NA NA them personally.

4 Contributes to overall mental health of students

NA NA

5 Increases attachment, pride, and belonging to school

NA 4.1

6 Creates a sense of ownership

NA 4.4

7 Heightens student motivation and enthusiasm

NA

NA

8 Improves student sense of self

NA 4.4

9 Empowers students to change their community

NA 4.3

10 Encourages cooperative group learning and teamwork

NA 4.6

11 Gives students opportunities to work together collaboratively

NA 4.4

12 Enhances school curriculum

NA 4.2

13 Encourages conservation and ecological commitment

NA 4.2

Engages students particularly with learning disabilities or attention challenges

NA 4

In addition to all the obvious environmental literacy benefits, the garden

15 provides a learning space where students who find sitting in a classroom

NA NA difficult a place to shine.

Note. $M=$ Group mean scores. R2 = Round two group mean scores. ${ }^{*}=$ met consensus criteria in R2 and was not re-rated. R3 = Round three group mean scores. NA = statement entered by participant in Round 3 and was not rated by group. 
Table 5

Research Objective One Delphi and Interview results: School Garden Startup

\begin{tabular}{|c|c|c|c|}
\hline Theme & & Delphi Results & Supporting Quotes from Interviews \\
\hline \multirow[t]{9}{*}{$\begin{array}{l}\text { Infrastructure } \\
\text { and Resources }\end{array}$} & 1. & $\begin{array}{l}\text { Secure start-up funding for garden } \\
\text { development, equipment, and materials }\end{array}$ & $\begin{array}{l}\text { "Funding is number 1." (G2-P4) } \\
\text { Funding is extremely important to } \\
\text { have a suitable program." (G2-P3) }\end{array}$ \\
\hline & 2. & $\begin{array}{l}\text { Ensure stakeholders understand and are } \\
\text { prepared to fund a multi-year } \\
\text { investment }\end{array}$ & $\begin{array}{l}\text { "These things take a lot of time and a } \\
\text { lot of money, and there's not a lot of } \\
\text { organizations in the school garden } \\
\text { world that are big enough to be able to } \\
\text { do that kind of work." (G1-P1) }\end{array}$ \\
\hline & 3. & Start with a manageable size & "I was surprised that the manageable \\
\hline & 4. & $\begin{array}{l}\text { Have an agreement with the school and } \\
\text { all stakeholders on the size, initial cost, } \\
\text { maintenance cost, and future plans of } \\
\text { the garden. }\end{array}$ & $\begin{array}{l}\text { size scored kind of low because I } \\
\text { think for us that was really important, } \\
\text { that we could start small and build it } \\
\text { as we needed to." (G4-P6) }\end{array}$ \\
\hline & 5. & $\begin{array}{l}\text { Know where to find free resources and } \\
\text { educational materials }\end{array}$ & $\begin{array}{l}\text { "Definitely start with something that } \\
\text { you know can be maintained and then }\end{array}$ \\
\hline & 6. & $\begin{array}{l}\text { Ensure garden access to students, staff, } \\
\text { and parents during school hours }\end{array}$ & $\begin{array}{l}\text { immediately start coming up with a } \\
\text { plan for how the school garden is not }\end{array}$ \\
\hline & 7. & $\begin{array}{l}\text { Creating a budget in facilities } \\
\text { operations to support maintenance of } \\
\text { the different growing structures }\end{array}$ & a one-person project." (G1-P2) \\
\hline & 8. & $\begin{array}{l}\text { Having a plan for the available space, } \\
\text { resources, and materials that are } \\
\text { available }\end{array}$ & \\
\hline & 9. & $\begin{array}{l}\text { Growing something students can } \\
\text { harvest and eat as early as possible in } \\
\text { the program }\end{array}$ & \\
\hline \multirow[t]{5}{*}{$\begin{array}{l}\text { Interest and } \\
\text { Buy-In }\end{array}$} & 1. & $\begin{array}{l}\text { Generating student enthusiasm by } \\
\text { connecting the garden with students' } \\
\text { coursework }\end{array}$ & $\begin{array}{l}\text { "The highest priority for making } \\
\text { school gardens work is just simply } \\
\text { buy-in from the school." (G1-P1) }\end{array}$ \\
\hline & 2. & $\begin{array}{l}\text { Buy-in from multiple stakeholders in } \\
\text { the school community (teachers, } \\
\text { students, school staff, and PTA }\end{array}$ & \\
\hline & 3. & $\begin{array}{l}\text { Securing a site with actively engaged } \\
\text { participants and an enthusiastic team }\end{array}$ & \\
\hline & 4. & $\begin{array}{l}\text { Ensuring top-down buy-in from the } \\
\text { school district and administration to } \\
\text { build support }\end{array}$ & $\begin{array}{l}\text { "It has to come from the } \\
\text { administrators to legitimize my } \\
\text { presence." (G3-P5) }\end{array}$ \\
\hline & 5. & $\begin{array}{l}\text { Celebrating garden program } \\
\text { achievements often }\end{array}$ & \\
\hline
\end{tabular}


Education and 1. Creating clear goals and linking them Student

Learning

Support to the schools goals

2. Providing the students with an outdoor experience with hands-on activities in nature

3. Connecting the garden with program activities with content standards across the curriculum

4. Educating students on food and nutrition as well as the importance of growing and eating local produce

1. Having a position designated for overall school garden management

2. Hiring a dedicated, knowledgeable skilled coordinator
"There's high importance of imbedding this within the curricular goals and I think treating the garden as a resource that is important to incorporate within those already existing classes." (G2-P3)

"I do think having a paid role, if it's regular school teacher who gets an extra stipend for being the person who can keep track of what is in the garden...or who to call for what to do." (G1-P2)

Note. $\mathrm{G}=$ interview/focus group number. $\mathrm{P}=$ participant number. 
Table 6

Research Objective Two Delphi and Interview Results: School Garden Sustainability

\begin{tabular}{|c|c|c|c|}
\hline Theme & & Delphi Results & Supporting Quotes from Interviews \\
\hline \multirow[t]{4}{*}{$\begin{array}{l}\text { Planning, } \\
\text { training, and } \\
\text { education }\end{array}$} & 1. & $\begin{array}{l}\text { Having a yearlong instructional } \\
\text { plan that is relevant and a part of } \\
\text { the overall school curriculum }\end{array}$ & $\begin{array}{l}\text { "It has to be taught in the classroom } \\
\text { also. Like regular classroom also." } \\
\text { (G3-P5) }\end{array}$ \\
\hline & 2. & $\begin{array}{l}\text { To connect the priorities of the } \\
\text { garden program to those of the } \\
\text { school and school culture }\end{array}$ & $\begin{array}{l}\text { "You could have a "successful school } \\
\text { garden program" that is not super } \\
\text { integrated into the school, as long as it } \\
\text { is integrated in some other component } \\
\text { of the school." (G1-P2) }\end{array}$ \\
\hline & 3. & $\begin{array}{l}\text { Providing training for teachers on } \\
\text { how to incorporate the garden as } \\
\text { an outdoor classroom }\end{array}$ & $\begin{array}{l}\text { "Sustainability of the school garden } \\
\text { remaining a part of the school culture } \\
\text { is really central to what we do because }\end{array}$ \\
\hline & 4. & $\begin{array}{l}\text { Having a clear, easy to follow, } \\
\text { standards-based curriculum, }\end{array}$ & $\begin{array}{l}\text { when we invest all that time and } \\
\text { money we want to make sure that by } \\
\text { the time we kind of walk away that we } \\
\text { have empowered teachers and that } \\
\text { we've really made the school garden a } \\
\text { big part of the core of that school's } \\
\text { identity." (G1-P1) }\end{array}$ \\
\hline \multirow[t]{4}{*}{$\begin{array}{l}\text { Interest and buy- } \\
\text { in }\end{array}$} & 1. & $\begin{array}{l}\text { Creating a sense of ownership } \\
\text { with the students }\end{array}$ & \\
\hline & 2. & $\begin{array}{l}\text { Buy-in and commitment from the } \\
\text { school administration }\end{array}$ & $\begin{array}{l}\text { "I think that that administrator } \\
\text { position needs to be less passive and }\end{array}$ \\
\hline & 3. & $\begin{array}{l}\text { Buy-in and commitment from the } \\
\text { teachers and staff }\end{array}$ & $\begin{array}{l}\text { more active, as in you would never } \\
\text { hire a teacher that doesn't have }\end{array}$ \\
\hline & 4. & Having an enthusiastic team & experience." (G2-P3) \\
\hline \multirow[t]{3}{*}{$\begin{array}{l}\text { Infrastructure } \\
\text { and resources }\end{array}$} & 1. & $\begin{array}{l}\text { Having continual access to } \\
\text { materials (seeds, plants, soil) to } \\
\text { maintain the garden }\end{array}$ & $\begin{array}{l}\text { "Having a really good design from the } \\
\text { beginning before you break ground as } \\
\text { opposed to just kind of like jumping }\end{array}$ \\
\hline & 2. & $\begin{array}{l}\text { To design space and plantings so } \\
\text { that growth occurs in phases } \\
\text { throughout the school year to help } \\
\text { decipher realistic yearly } \\
\text { maintenance }\end{array}$ & $\begin{array}{l}\text { right in, I think it pays off in terms of } \\
\text { sustainability." (G1-P1) }\end{array}$ \\
\hline & 3. & $\begin{array}{l}\text { Ensuring that supplies and } \\
\text { materials are well-organized and } \\
\text { are based on the age group of the } \\
\text { students }\end{array}$ & \\
\hline \multirow[t]{2}{*}{ Support } & 1. & $\begin{array}{l}\text { Involving all teachers in the } \\
\text { garden }\end{array}$ & $\begin{array}{l}\text { "If he were to leave, you know, yeah, } \\
\text { we would have to find someone else }\end{array}$ \\
\hline & 2. & $\begin{array}{l}\text { Hiring a full-time, knowledgeable } \\
\text { coordinator to manage and }\end{array}$ & who cares deeply enough to do that or \\
\hline
\end{tabular}


maintain the school garden program it would in fact, kind of die out." (G4P6)

"Like a point person that has some logistical skill and reliability and I think that it's important that that person is not simply a volunteer because volunteers it's more likely that a volunteer is going to leave." (G1-P2)

Note. $\mathrm{G}=$ interview/focus group number. $\mathrm{P}=$ participant number. 
Table 7

Research Objective Three Delphi and Interview Results: School Garden Benefits

\begin{tabular}{|c|c|c|}
\hline Theme & Delphi Results & Supporting Quotes from Interviews \\
\hline \multirow{7}{*}{$\begin{array}{l}\text { Education and } \\
\text { cooperative } \\
\text { learning }\end{array}$} & Encourages cooperative group & "Positive results is the students are able \\
\hline & learning and teamwork & to connect to what they're doing." (G3- \\
\hline & Enhances school curriculum & P5) \\
\hline & $\begin{array}{l}\text { Encourages conservation and } \\
\text { ecological commitment }\end{array}$ & $\begin{array}{l}\text { "Schools garden impact students through } \\
\text { environmental literacy and awareness, } \\
\text { they become more connected with their } \\
\text { environment." G2-P3) }\end{array}$ \\
\hline & $\begin{array}{l}\text { Engages students particularly with } \\
\text { learning disabilities or attention } \\
\text { challenges }\end{array}$ & $\begin{array}{l}\text { "This is a very immediate thing that can } \\
\text { really be a gateway for some of our } \\
\text { students, especially the ones for whom } \\
\text { school is not a successful enterprise, this } \\
\text { is a gateway." (G4-P6) }\end{array}$ \\
\hline & $\begin{array}{l}\text { Gives students opportunities to work } \\
\text { together }\end{array}$ & \\
\hline & $\begin{array}{l}\text { In addition to all the obvious } \\
\text { environmental literacy benefits, the } \\
\text { garden provides a learning space } \\
\text { where students who find sitting in a } \\
\text { classroom a difficult place to shine }\end{array}$ & $\begin{array}{l}\text { "Students out there are grasping a lot of } \\
\text { concepts when they were working } \\
\text { outside that they were really struggling } \\
\text { with inside." (G1-P1) }\end{array}$ \\
\hline \multirow{5}{*}{$\begin{array}{l}\text { Student self- } \\
\text { worth, } \\
\text { motivation, } \\
\text { and } \\
\text { community } \\
\text { engagement }\end{array}$} & $\begin{array}{l}\text { Heightens student motivation and } \\
\text { enthusiasm }\end{array}$ & $\begin{array}{l}\text { "What a great way to get these kids, to } \\
\text { increase their student confidence within } \\
\text { themselves, I've noticed that here. } \\
\text { Especially around gardening," (G4-P7) }\end{array}$ \\
\hline & Creates a sense of ownership & "I actually heard a student who is a 5th \\
\hline & Improves student sense of self & grader at one of our planning meetings \\
\hline & $\begin{array}{l}\text { Empowers students to change their } \\
\text { community }\end{array}$ & $\begin{array}{l}\text { that we invite students to before we build } \\
\text { the garden, he literally stood up in the }\end{array}$ \\
\hline & $\begin{array}{l}\text { Increases attachment, pride, and } \\
\text { belonging to school }\end{array}$ & $\begin{array}{l}\text { meeting and said that the thing he was } \\
\text { most excited about was that his school } \\
\text { was finally going to have one of the nice } \\
\text { things that some of the schools in the rich } \\
\text { part of D.C had. He's } 10 \text { years old and } \\
\text { he's like fully aware of that." (G1-P1_- }\end{array}$ \\
\hline \multirow[t]{3}{*}{$\begin{array}{l}\text { Health and } \\
\text { Wellness }\end{array}$} & $\begin{array}{l}\text { Increases fruit and vegetable } \\
\text { consumption }\end{array}$ & $\begin{array}{l}\text { "Having less diet related illnesses... then } \\
\text { appreciating them in later in life }\end{array}$ \\
\hline & Healthy way of eating & $\begin{array}{l}\text { hopefully being healthier eaters." (G2- } \\
\text { P3) }\end{array}$ \\
\hline & $\begin{array}{l}\text { Students learn about how foods or } \\
\text { produce is actually grown, the } \\
\text { nutritional benefit adding vegetables } \\
\text { as a part of one's overall diet, and }\end{array}$ & $\begin{array}{l}\text { "For kids to know where their food is } \\
\text { coming from to be able to grow their } \\
\text { own food and to know what healthy food } \\
\text { is, I think that like a long term impacts of }\end{array}$ \\
\hline
\end{tabular}


most importantly learning lifelong that on both them and their family and skills that will benefit them communities." (G2-P4)

personally

Contributes to the overall mental

"All those extra benefits of just extra health of students types of social-emotional learning that you don't necessarily get in a classroom." (G1-P1)

Note. $\mathrm{G}=$ interview/focus group number. $\mathrm{P}=$ participant number. 
Table 8

Interview and Focus Group Results: Research Objective, Themes, and Subthemes

\begin{tabular}{|c|c|c|c|c|c|}
\hline & Research Objective & & Themes & & Subthemes \\
\hline \multirow[t]{13}{*}{ I. } & Successful School Garden & A. & Buy-In & 1. & Proof of impact of garden \\
\hline & Start-Up (Q1) & & & 2. & School staff and administration \\
\hline & & B. & Planning & 1. & Team and vision \\
\hline & & & & 2. & Size and design \\
\hline & & & & 3. & Funding, materials, and resources \\
\hline & & & & 4. & School curriculum and goals \\
\hline & & C. & Support & 1. & Garden coordinator/point person \\
\hline & & & & 2. & Policy \\
\hline & & & & 3. & Administration \\
\hline & & & & & Partnerships \\
\hline & & D. & Barriers & 1. & Perceptions of stakeholders \\
\hline & & & & 2. & Time and money \\
\hline & & & & & $\begin{array}{l}\text { School priorities and teacher } \\
\text { comfortability }\end{array}$ \\
\hline \multirow[t]{13}{*}{ II. } & Sustainable School & A. & School Goals & 1. & School culture \\
\hline & Garden Programing (Q2) & & & 2. & Curriculum integration \\
\hline & & B. & Support & 1. & Garden coordinator \\
\hline & & & & 2. & Teachers and administration \\
\hline & & & & & Parent and family involvement \\
\hline & & & & & Partnerships and collaboration \\
\hline & & & & 5. & Values and commitment \\
\hline & & & & 6. & Funding, design, and maintenance \\
\hline & & C. & Barriers & 1. & $\begin{array}{l}\text { Money, resources, time, and growing } \\
\text { season }\end{array}$ \\
\hline & & & & 2. & Integration into school curriculum \\
\hline & & & & & Coordinator or point person \\
\hline & & & & & Collaboration \\
\hline & & & & & Buy-in and perceptions \\
\hline \multirow[t]{12}{*}{ III. } & Perceived Benefits (Q3) & A. & Student & 1. & Academics \\
\hline & & & Learning & 2. & $\begin{array}{l}\text { Student engagement and learning } \\
\text { environment }\end{array}$ \\
\hline & & & & & Empowerment and ownership \\
\hline & & & & & Environmental awareness \\
\hline & & & & & Students with challenges \\
\hline & & B. & School Culture & 1. & Pride of place \\
\hline & & & & & School community \\
\hline & & C. & Health and & 1. & Food exposure and awareness \\
\hline & & & Wellness & & Willingness to try new things \\
\hline & & & & & Future Health \\
\hline & & & & & Social Emotional \\
\hline & & & & 5 . & Physical Activity \\
\hline
\end{tabular}




\section{Figures}

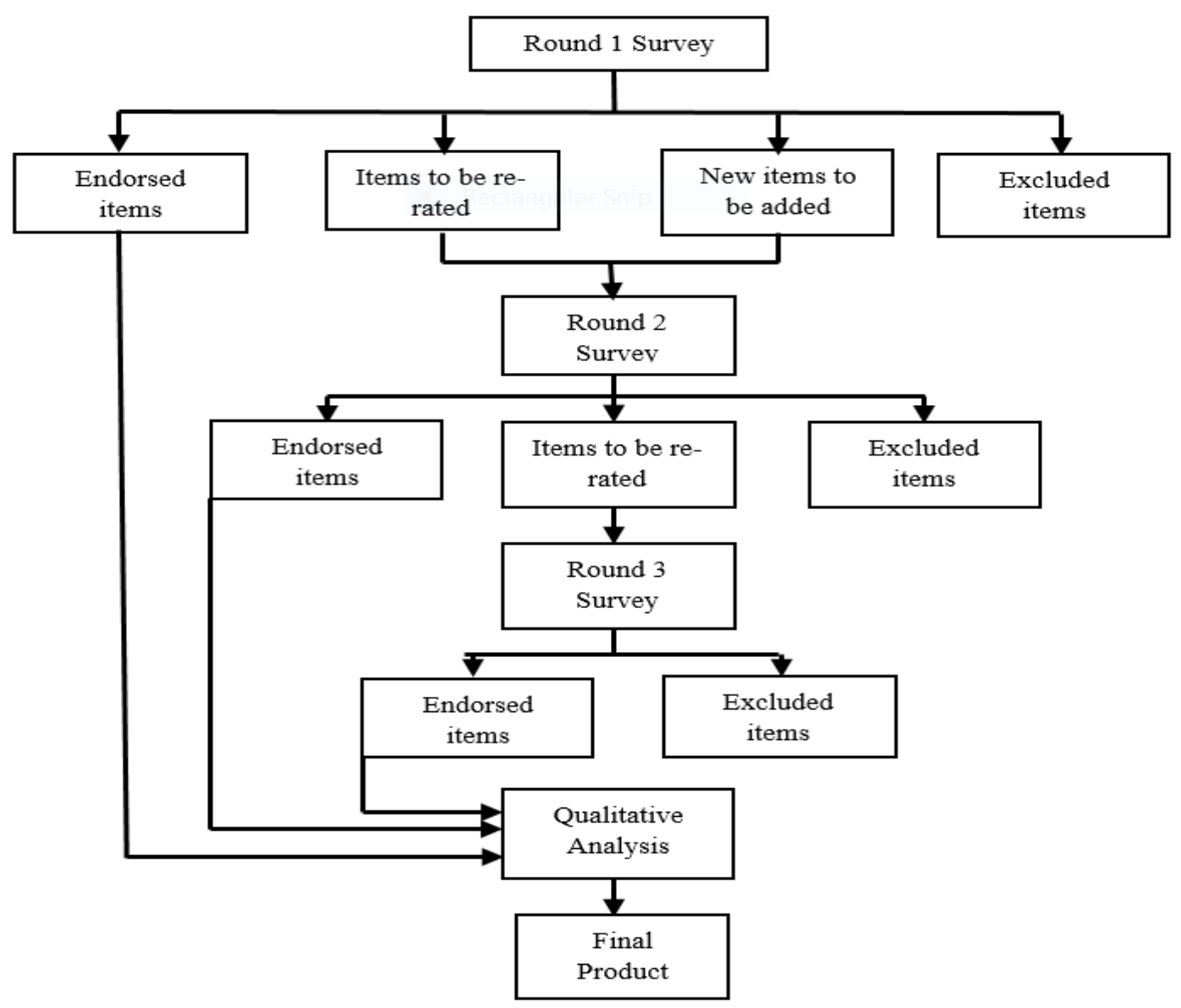

Figure 1. Design and procedures of this 3-round Delphi study and follow-up qualitative analysis. 


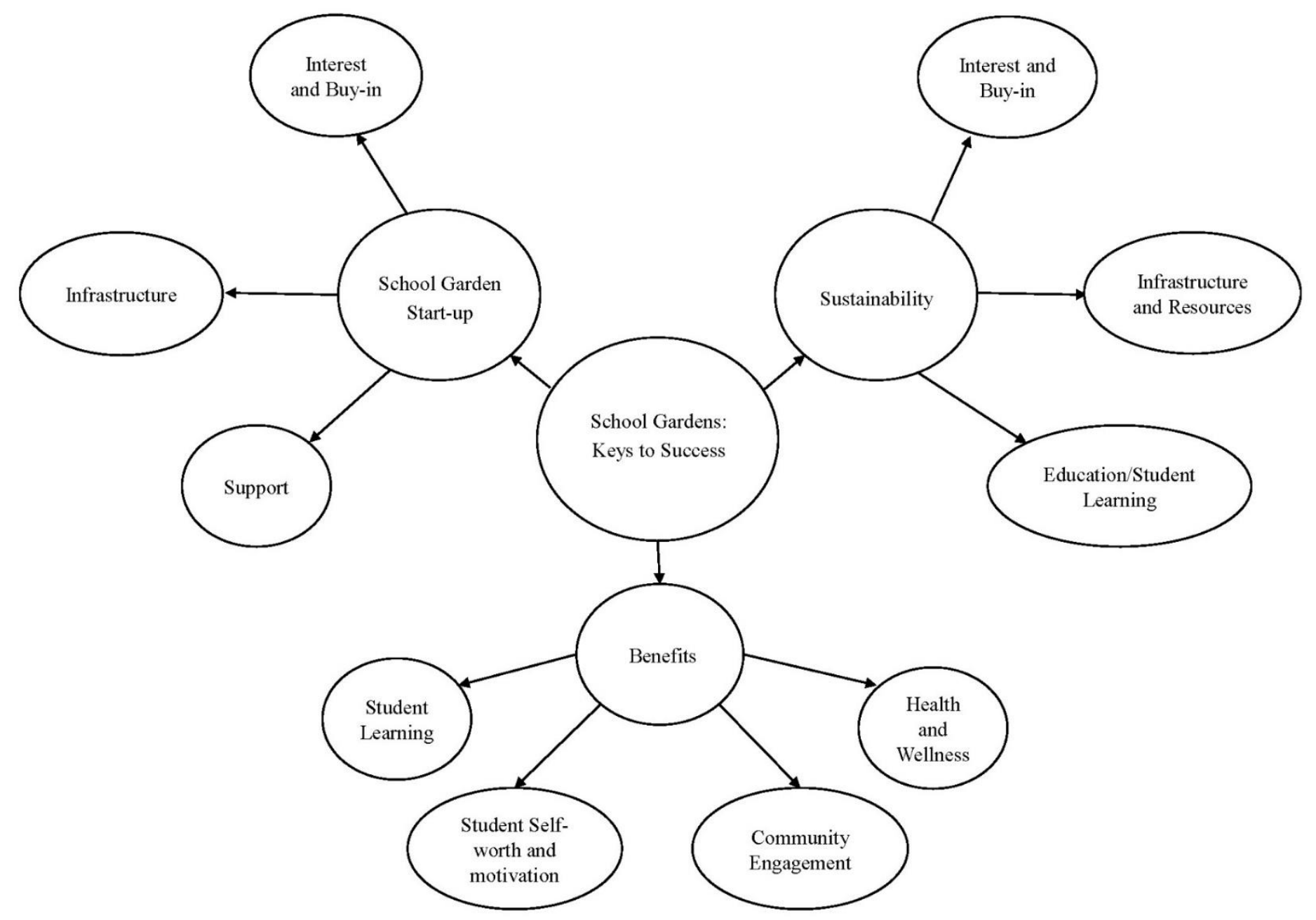

Figure 2. Graphical Representation of the Delphi Results by Concepts and Theme 


\section{Appendices}

\section{Appendix A: Extended Literature Review}

\section{Extended Review of Literature}

This review explores the literature related to school gardens and the associated uses, strategies, benefits, impacts, outcomes and best practices and recommendations for a successful school garden program. The first and second sections of the literature review provide an overview of school garden program history and the contemporary uses. These two sections also discuss what is occurring on an international, national, and local level, with a focus on Washington, DC schools. The third and fourth sections focus on strategies, evaluations, impacts, and best practices relating to school garden programming. These two sections explore the impact of school gardens academics, environmental attitudes, children's health, and family and community perspectives. The fifth section examines the impacts, outcomes, and suggestions for moving school garden programs forward in the United States. The final section is an overview of the consensus building technique used for this study, the Delphi method.

\section{Overview of School Gardening}

School gardens have a long history of marrying nature and education. Although school gardens are well-known for bringing life back to the American people during the two World Wars, gardens first gained popularity in the educational landscape. Gardens have long stood as examples of educational and social philosophies and theories that benefit America's youth. They have symbolized freedom while bolstering the American spirit during times of hardship and turmoil. While nourishing the souls and bodies of the American people, the gardens served as an excellent resource for healthy living and healthy learning through education of the natural world (Desmond, Grishop, \& Subrmaniam, 2002; Halpern, 2002; Hayden-Smith, 2010; Lawson, 2005). 
The History of School Gardens. School gardens began in the United Stated in the late 1800s after being modeled from European gardening programs. The original purpose of the school garden was multifold; gardens were a different educational tool that focused on scientific agriculture, horticulture education, and the acquisition of vocational skills (Hayden-Smith, 2014). A few progressive educators in the early $20^{\text {th }}$ century grasped onto the concept of school gardens and created a movement that "studied nature, not books", coined as the Nature-Study Movement (Bailey, 1904). School gardens and natural learning have a rich history connected to John Amos Comenius, Jean-Jacques Rousseau, Friedrich Frobel, Maria Montessori, John Dewey, and Liberty Hyde Bailey, all who were Progressive Education forerunners of their time (Subramaniam, 2002; Trelstad, 1997). During the Gilded Age and Progressive Era (1890- 1920), school gardens became a coast-to-coast interest with estimates of 75,000 school gardens in existence by 1906 (US Department of Agriculture, 2011). School gardens gained the attention of the United States Bureau of Education leading to the funding and development of the Division of Home and School Gardening (Lawson, 2005; Jewel, 1907; Trelstad, 1997). Many organizations and professionals supported the establishment of school gardens because of the positive effects they had on civic improvement, education, safety, and social and moral development (Lawson, 2005). Late into the Progressive Era, over two million U.S. soldiers joined the allies to fight in World War I, and the role of the school garden shifted.

During World War I, the United States School Garden Army (USSGA) turned the land into acres of fruitful production to respond to the needs of countries in crisis (Meyer, 1997; Trelsted, 1997). Explicitly, the war was threatening the food supply in the U.S. and Europe as well. To increase fruit and vegetable consumption and improve the health of the U.S. population, the USSGA enlisted "soldiers of the soil" (millions of school-aged boys and girls) to grow foods 
at schools, known as victory gardens (Hayden-Smith, 2014). The notion that "food will win the war" became very popular, and gardens proceeded to engage the imagination and energy of millions of Americans (Lawson, 2005; Hayden-Smith, 2014). In 1942, Americans established an estimated 15 million gardens that produced 7.5 billion pounds of food - totaling 40 percent of the domestic vegetable supply in the U.S. (It is essential to gather expertise in assisting in the movement so that more projects are successful (Danks, 2010). Urban Sprouts, 2009). During World War II, victory gardens were needed once again to contribute to the effort. However, efforts quickly faded in 1944, and by the 1950s, both economic and academic priorities had changed, and school gardens were no longer viewed with such importance (Halpern, 2002; Subramaniam, 2002, \& Blair, 2009). Lawson (2005) discussed that the victory garden campaign provided "insight into what it takes to support a national, albeit a temporary, garden campaign and may shed light on what is necessary" to sustain garden programs permanently (p.181). School gardens have a long history of ups and downs and sprouted and grew through war, necessity, education, and beautification. The support for environmental education and healthy schools has also aroused interest in school gardens in more recent years, and since the turn of the $21^{\text {st }}$ century, interest in school gardens has once again gained popularity (Desmond et al., 2002).

Theoretical and Philosophical Background. This study does not identify with a specific theoretical framework or philosophy but provides a brief overview of what is most frequently tied to school garden programming and research. The application of school gardens varies across the educational landscape, as do the philosophies and theoretical frameworks behind garden-based education. Typically, a combination of theoretical frameworks/behavioral theories are associated with garden-based learning: experiential education, environmental education, and 
ecological theory. Teaching children through personal discovery in a natural setting is the common thread between these theories (Subramaniam, 2002).

Learning experientially in authentic contexts has long been used as a model of teaching and learning in agriculture education and has been traced back to some of the most prominent philosophers and leaders in the field of education (Subramaniam, 2002; Knoblock, 2003;

Desmond, Grieshop, \& Subramaniam, 2004). The Association for Experiential Education described experiential education as "a process through which a learner constructs knowledge, skill, and value from direct experiences” (Luckmann, 1996, p.7). Many early philosophers dating as far back as the seventeenth century - believed that education should be collective, hopeful, hands-on, and innovative. John Amos Comenius (1592-1670) stated that "a school garden should be connected with every school, where children have the opportunity to" learn about and appreciate nature (Weed, 1909, cited in Sealy, 2001). Comenius also stated that "since the senses are the trustiest servants of the memory, this method (gardens) of sensuous perception will lead to the permanent retention of knowledge" (Keating, 1896, p. 185). Jean-Jacques Rousseau (1712-1778) later emphasized that nature was the child's greatest teacher and foundational for later learning (Sealy, 2001). Towards the end of the $19^{\text {th }}$ century, Friedrich Froebel (1782-1852) was one of the most effective proponents of school gardens and emphasized learning by doing. Focusing on a more hands-on, sensory-based approach to learning, Froebel believed that the feet, hands, and eyes served as the primary masters of knowledge (Boyd, 1956). Moving forward into the $20^{\text {th }}$ century, Maria Montessori (1870-1952) believed that a garden could help children develop morally and in their appreciation towards nature. To complete the list of early school garden innovators, philosopher John Dewey (1859-1952) believed in the importance of incorporating gardening into education and viewed the garden as a chance for 
children to experience greater freedom for experiencing real-life situations and applications providing progressive experiences (Dewey, 1915).

Learning by doing (Knapp, 1952), learning in real-life context (Dewey, 1915), learning through projects (Stimson, 1919), and learning by solving problems (Lancelot, 1944), are what make up the four tenets of experiential learning in this context (Knobloch, 2003). Others found relevance between school gardens and educational theories including Howard Gardener's (1983) theory of multiple intelligence and Daniel Goldman's (1995) theory of emotional intelligence (Desmond, Grieshop, \& Subramaniam, 2002). Gardner claimed that just as most children are ready to master language at an early age, so too are they predisposed to explore the world of nature.

\section{Contemporary Uses of School Gardens}

School garden programs have been on the rise since the mid-1990s and have gained popularity across educational landscapes. The contemporary push to progress the school garden movement worldwide is largely influenced by educators, environmentalists, and agricultural crusaders (Subramaniam, 2002; Childs, 2011). According to a study that examined the prevalence of school garden programs in U.S. public elementary schools, the prevalence of school garden programs has increased over the past seven years from 11.9 percent in 2006-2007 to 31.2 percent in 2013-2014 (Turner, Eliason, Sandoval, \& Chaloupka, 2016). These programs also vary widely in scope, the intensity of participation, and integration into the regular school curriculum - even within the same school district. Regardless of the diversity and varied school characteristics, school gardens can thrive anywhere - "in both cold and warm climates, and in urban, suburban, and rural communities. School gardens exist in schools with no bare ground, and in schools with acres of land" (LifeLab, 2007, p. 9). These living laboratories can range 
from a few small planter boxes in a classroom to a large outdoor garden with an expanse of plantings and are unique in that they provide a different context for students to learn about the world they live in.

School Garden Characteristics. School gardens, also referred to as "green schoolyards," serve as environmentally beneficial spaces where children and communities can gather to be physically active, play, participate in a rich physical education program, and experience a hands-on lesson that supports the curriculum (Bowman, Adelman, \& Davis, 2015). Physical elements found in green schoolyards may include safe play equipment for all ages, benches and natural elements for seating or gathering, jogging tracks, native gardens, outdoor classrooms, and vegetable gardens. Other key aspects of green schoolyards may include: open to the community after school and on weekends; provides hands-on, outdoor learning opportunities for all subjects including STEM (science, technology, engineering, and mathematics) education; provides places for children to experience nature; supports physical education; and supports healthy eating and nutrition (Bowman, Adelman, \& Davis, 2015). To encourage teachers to integrate different subject areas, LifeLab (2007) suggests creating theme gardens such as history, butterfly, ecosystem, heritage, and nutrition gardens.

When asked in a survey about the garden environment and related practices at their school, California principals $(\mathrm{N}=4,194)$ responded with the following details of their school garden programs. Demographic data showed that the majority of gardens were located in urban schools $(73 \%)$ and the other garden programs were located in rural schools $(27 \%)$ in California. Of the schools that answered yes to having a school garden $(n=2,381)$, gardens were predominantly located in elementary (64\%) and K-8 schools (60\%). Most of the gardens were in the ground (69\%) or a raised bed (60\%), with less than half $(46 \%)$ of the gardens composed of 
potted plants or off school campus (Graham, Beall, Lussier, McLaughlin, \& Zidenberg-Cherr, 2005). Throughout the nation, elementary and primary schools, lead the way for school garden implementation.

Skelly and Bradley (2007) studied the variation in school garden types and provided classifications of the school garden programs into a typology matrix. The typology was formulated by using the factors of intensity, measured by the number of garden-related activities students participated in prior to and while in the garden (high, medium, and low) and the form of school gardens (flower, vegetable, or combination flower/vegetable). Garden intensity and form were cross-tabulated to form nine categories that constituted the conceptual "types" of school gardens: (a) low-intensity vegetable garden, (b) low-intensity flower garden, (c) low-intensity combination garden, (d) medium-intensity vegetable garden, (e) medium-intensity flower garden, (f) medium-intensity combination garden, (g) high-intensity vegetable garden, (h) high-intensity flower garden, and (i) high-intensity combination garden. After this typology was created, correlation analysis showed that it significantly correlated with other possible typologies and was effective in explaining school garden intensity and type. The results of this study determined there were significant differences in the nine types of school gardens, but there was no trend found concerning garden intensity and form that may link to superiority or effectiveness of one type (Skelly \& Bradley, 2007).

In many schools throughout the world, gardens are being integrated into the educational curriculum to teach children about plants, nature, science, and life skills. Research has shown that such programs have had a notable impact on student education (standardized achievement tests), involvement, and personal self-efficacy (enthusiasm for learning) and confidence (Wansink, Hanks, \& Just, 2015; Blair, 2009; Lineberger \& Zajicek, 2000). Whether it is used as 
an intervention program for nutrition and physical activity, or as a tool to diversify learning in the schools, school gardening has proved to be an excellent mode of healthy living/learning for all ages. Also, school gardens can contribute to children's development in a social, moral, and practical or life skills sense (Beery, Adatia, Segantin, \& Skaer, 2013). Orr (1992, 1994) wrote about the value of outdoor experience on child development. In his book, Ecological Literacy, Orr states that "children raised in ecologically barren settings are deprived of the sensory stimuli and the kind of imaginative experience that can only come from biological richness".

National Trends. In 1995, California's State School Superintendent mandated that there should be "a garden in every school" to create opportunities for the "children to discover fresh food, make healthier food choices, and become better nourished" (Subramaniam, 2002, p.4; Collective School Garden Network, 2015). This movement was largely influenced by educators, environmentalists, and agriculture reformists. The school garden revolution in California sparked the interest of schools and educators worldwide; paving the way for diverse programming and curricula. Another program that developed from California's state school garden mandate was The Edible Schoolyard project. Waters (2016) developed The Edible Schoolyard in Berkeley, California and promotes schools having gardens for food production and as well as teaching compassion, patience, and self-discipline. The program involves students in all aspects of farming, including preparing, serving, and eating the food harvested. Lessons are fully integrated into academic subjects and support content standards, Common Core Standards, and Next Generation Science Standards. The program is also designed to achieve a specific set of edible education learning goals and life skills - communication, personal and community stewardship, flexibility, and perseverance. The Edible Schoolyard reflects this belief 
as a model in education regarding social responsibility, community participation, and sustainable agriculture (The Edible Schoolyard Project, 2016).

Multiple organizations, cities, and states have followed California's school garden movement including Boston Public Schools, Cambridge Public Schools, and elementary schools in Texas (Hirschi, 2015). One organization specifically played a significant role in spreading the movement - the American Horticulture Society (AHS) that hosts the Children's Garden Conference series (Desmond, et al., 2004). AHS created the first Youth Garden Symposium in 1993 and sought to educate and inspire people to look at garden design as a way to reconnect children with nature. The National Garden Association is another organization that has taken an active role in school gardening and offers resources for starting and maintaining gardens in schools. The number of schools across the nation that are joining the school garden movement grows daily. More specifically, the District of Columbia has experienced tremendous growth over the last seven years with their school garden program.

Trends in the District. After passing the Healthy Schools Act of 2010 (DC Law 18-209; DC Official Code $\S 38$ - 821.01 et seq), DC has become "a beacon to other cities" for school garden programming (Higgins, 2016). Making school gardening a major component of the Healthy Schools Act proves that policy makers and legislators in DC understand the importance of a school garden and the related benefits. The garden is a place to promote physical activity, healthy food choices, and wellness, and can help fill the gaps when recess or physical education has been reduced or even eliminated. This piece of legislation ensures that all schools in the district are a healthy place for all students and have required improvement and annual reporting on school garden programming and health and physical education programming (The Office of the Superintendent of Education (OSSE), 2016). According to DC's 2016 Healthy Schools Act 
School Garden Annual Report, there are currently a total of 127 schools (out of 233) with active gardens - an increase of 54 percent since the school year, 2011-2012 (OSSE, 2016; Ullery, 2016). Elementary schools in the district remain the most common (80\%) grade-level engaged in the program. According to the 2016 report, the school gardens are utilized before, during, and after the school day; with most of the activity occurring during the school day. During the 2015 school year, over 5,491 students received 3,040 hours of garden-based instruction, 315 teachers used the garden to teach 1, 130 lessons, and 17 garden-based organizations provided support (OSSE, 2016). The topics most frequently taught in the school garden include nutrition and the environment, but the data also showed that science, technology, engineering, STEM, English, and art were used. Not only are the topics that are taught diverse but the type of school garden varies within the district including four different types: edible gardens; storm water or rain gardens; pollinator, native, or wildlife gardens; and greenhouses. Unlike many school garden programs in the nation, over 55 percent of the schools have designated school garden coordinators.

OSSE in conjunction with Washington, DC government agencies, community organizations, food service providers, public schools and public charter schools help develop programs to promote the benefits of purchasing and eating locally-grown and unprocessed foods that are from growers engaged in sustainable agricultural practices. Also, OSSE is required to conduct at least one program per year, such as an annual flavor of the week or a harvest of the month program, in collaboration with other district agencies and non-profit organizations (OSSE, 2010). With one goal in mind, non-profit, government, and education programs such as The Edible Schoolyard, REAL School Gardens, Food Corp, DC Greens, and the school garden specialist at OSSE, aim to improve the health and wellness of the students and to promote 
lifelong healthy eating habits (OSSE, 2010). Another major component of the school garden program in DC involve the distribution of competitive grants that support the creation and maintenance of school gardens as part of the schools' curricula and broader programs (Ray, Fisher, \& Fisher-Maltese, 2016). The program has distributed sixty-six grants throughout the district to teachers or principals who have applied, and the grant program continues to grow through a partnership with Food Corps (Ullery, 2016). Food Corps is an AmeriCorp program that focuses on high-needs schools and connecting children to healthy foods in schools by implementing hands-on gardening and cooking lessons, as well as providing healthy options in school cafeterias (Food Corp, 2016). The funding is one barrier that most school garden programs in America face that the DC school garden programs do not struggle with - the funding provided to the district does not translate elsewhere in the nation.

DC Greens was founded in 2009 and is involved in the city's healthful-food access programs - including a training program for school garden coordinators. Following Michelle Obamas "Let's Move” campaign, DC Greens was motivated to carry on her legacy of addressing the nation's obesity problem through food education (DC Greens, 2016). DC Greens also operates the city's "Fruit and Vegetable Prescription Program," through which Unity Health Care prescribes fruits and vegetables to low-income patients. Those patients can take the prescriptions to designated places where they can collect their produce. In 2017, DC Greens received local and federal grants, private donations and sponsorships, totaling almost $\$ 2.3$ million dollars. Holway and Biel (DC Green directors) discuss that the teachers involved in school gardens were no longer working in isolation and built a network of local educators associated with school nutrition (Stein, 2016). In the past seven years, school gardens evolved from small patches of inconsistently plowed land that science teachers would use to teach 
children about plants and have become gardens that teach children about healthy living, science and social sciences (Stein, 2016). As school gardens gain popularity across the U.S., understanding their potential impacts on diverse communities becomes increasingly important.

DC garden study. With exposure to school gardens, lower-income communities could see positive results related to student academic achievement, environmental attitudes, and nutrition knowledge (Ray, Fisher, \& Fisher-Maltese, 2016). However, there is a lack of research examining how the effects of school garden programs vary by the racial and class composition of the student body. With DC having a formal and successful school garden program, Ray, et al., aimed to understand the relationship between the presence of school gardens and academic achievement and how they are linked to reducing race and class inequality, within the District. The study's research questions included: 1) The presence of a school garden positively associated with student test scores in math, reading, and science? and 2) Do school gardens help to attenuate the association between race and social class composition and academic achievement? (Ray, et al., 2016). Using DC standardized test data to examine all fifth-grade students attending Washington, DC public schools, the researchers used quantitative methods to look at the differences between traditional and garden-based learning. The presence of a garden at a school served as the main independent variable. Based on the total number of test takers in each school, the percentage of White, Black, Hispanic, and free or reduced lunch students were provided by OSSE (Ray, et al., 2016). The researchers of this study also mapped the locations of all active school gardens through the 2012-2013 school year. The study included a map showing the school gardens by the percentage of Black residents in the neighborhood as well as a map illustrating school gardens by median household income. DC proved to be highly segregated by income and race, however, the school gardens were well distributed throughout the Districts 
eight Wards (Ray, et al., 2016). Results of this study included that students in schools with gardens produce higher science and reading scores but math scores remained steady, when compared to schools without a garden. Showing that the presence of gardens is associated with students having higher math scores than students in non-garden schools $(\mathrm{p}<.10)$. However, controlling for the proportion of Black and Hispanic students in the school, the association between school gardens and math scores become non-significant ( $p>.10)$ and the presence of school gardens is still associated with higher reading scores $(\mathrm{p}<.01)$. Though programming varies both in formal and informal education settings, the objectives for school gardening emphasize strategies and goals for learning impact and has the potential to open a gateway environmental stewardship and civic participation (Ray, et al., 2016).

International Trends. Internationally, numerous school garden programs exist. Learning through Landscapes (LTL) is an organization in the United Kingdom that attempted to move school grounds to the top of the educational agenda (Learning through Landscapes, 2002; Subramaniam, 2002). The goals of LTL focus on the school garden both for urban and rural schools as a way to help understand the difference between the two settings. LTL recognizes the importance of gardening, through which children gain firsthand experience with the seed-to-seed cycle, the rhythm and traditions of the harvest, and the taste, touch, and smell of fruit, vegetables, and flowers (Learning through Landscapes, 2002). Natural England is another program that promotes the natural environment for health and well-being benefits. With interest in encouraging school children to get out in nature, Natural England has a program referred to as One Million Children Outdoors (England, 2009) and explores the difference in contact with nature between today's generations of children compared to their parents. Using on online survey, 1150 adults and 502 children participated in the two-part survey. When asked where 
they played most, respondents ranked the locations and the top three locations for both adults and children were at home indoors $(83 \%)$, in the garden $(75 \%)$, and in the streets near their home (74\%). The results of the survey showed less variation between where males and females play among children and that girls were more likely to spend time in the garden, compared to the boys. The results of this survey could be used to promote the need to make natural spaces more available for children today.

In African schools, there has been little focus on practical skills in the curriculum however, the scene is gradually changing with the implementation of new educational policies (Horst, Morna \& Jonah, 1990; Desmond, Grieshop, \& Subramaniam, 2004). For example, Niger schools recently made gardens the main element in their new education policy as well as Sierra Leone where almost 80 percent of schools have hands-on gardening classes (Desmond, et al., 2004). It is suggested that after gardening in schools, children are more likely to help their parent's farm at home and are more eager to show them what they have learned from being in the garden (Desmond, et al., 2004; Subramaniam, 2002).

In Bolivia, the Schoolyard Ecology program is an organization focused on ecological conservation that uses the schoolyard as an extension of the classroom where children experience a hands-on laboratory for developing academic skills. This program, as well as many others across the world, are setting a new trend for curricular models and teaching methods.

Academic achievement. Used as an alternative teaching method to meet subject standards, teachers have been using gardening for science, mathematics, language arts, nutrition, geography, literature, physical education, and health science (Williams \& Dixon, 2013). In 2011, the Life Lab California School Garden Survey was distributed to schools across the state of California. Respondents $(n=545)$ were asked if the school garden was used for academic 
instruction (88.4\% responded, yes) and what subjects were used to teach in the garden. The respondents rated teaching science $(96.8 \%)$ at the highest, English/Language arts second (74.8\%), math at third (67.3\%), and History/Social studies last (55.7\%). Although science lessons are often thought of as the most natural fit in the school garden curriculum, the classroom garden can also act as a springboard for a wide-range of lessons in mathematics, history-social sciences, English-language arts, physical education and health, etc. (Omeje, 2016). “Gardenbased learning should not be viewed as an adjunct to the primary curriculum but rather as an interdisciplinary portal through which places and subjects can be explored and woven together" (Green, 2008, p. 15). With such a wide variety of subjects and content being taught, there is a need for research to be conducted as to the extent in which school gardening meets academic outcomes, if school gardens are to gain legitimacy in academic settings (Williams \& Dixon, 2013). A nationwide, comparative study by Lieberman and Hoody (1988) examined the effects on learning and instruction of using the environment as an integrating context in K-12 schools. The study included 40 schools (15 elementary, 13 middle, and 12 high schools) from across the US and examined the achievement data from language arts, math, science, and social studies; core curriculum and what was integrated into environment-based education. Interviews, surveys, and attitudinal measures gathered from students $(n=400)$, and teachers and administrators $(n=250)$, compiled the data on the effects on students, learning, teachers, and instructions. The study compared data from both traditional students and those that were taking part in the Environment as an Integrating Context for learning curriculum (EIC). Data collected from the schools included: comprehensive and subject-specific standardized tests, grade point averages, disciplinary actions, attendance, and student attitude measures. Quantitative measures were used to assess the academic benefits of EIC-based learning. Only 14 of the 40 schools $(n=39)$ 
documented standardized testing scores for the comparative analysis for both EIC and traditional students. Thirty-six of the thirty-nine comparisons (93\%) of academic achievement indicated that EIC students outperformed traditional students in reading, writing, math, science, and social studies. The educators that responded to the Learning Survey (77\%) reported that students' GPA's increased after their school implemented EIC programs. Other significant findings from the study indicated that students' increased engagement in learning, with EIC-based instruction, translated directly to positive changes in classroom behavior. All schools reported an increase in student behavior and attendance rates after implementing an EIC program. For example, Huntingdon Area Middle School experienced having 97 percent fewer incidents than other sixth graders not in an EIC program. Overall, students demonstrated positive effects in overall learning and personal responsibility in an integrated, environment-based program.

A more recent study by Williams and Dixon (2013) conducted a comprehensive synthesis of twenty years of garden-based learning literature. The authors considered forty-eight studies examining the impact of garden-based learning on students' academic outcomes. Half of these studies were quantitative, approximately a quarter were qualitative, and the other quarter were mixed-methods. Twenty-two of the studies measure direct academic outcomes such as improved grades, increased knowledge, and positive changes in attitudes and behavior. The other twentysix studies were focused on children's physical activity and fruit and vegetable consumption. It was noted that 90 percent of the studies did not report ethnicity of the students, 63 percent did not report socioeconomic status, and 25 percent did not define if the school was public or private. Overwhelmingly, studies have shown that garden-based learning has a positive impact on students' academic outcomes. However, Williams and Dixon (2013) as well as Blair (2009) 
stressed that there is still a lack of rigorous quantitative methodological research and the need for further research reflecting the comprehensive learning experience in the garden.

Mathematics and Language Arts. Nature is filled with numerical mysteries - space and shape logistics that make algebra a natural fit for the classroom garden. For example, a lesson focusing on measuring height, weight, and depth, the garden is used to identify threedimensional objects and measure the area of the classroom garden. Another example of a mathematically focused lesson involves estimating the number of seeds inside a fruit and vegetable. Students count the seeds, use subtraction or fractions to examine differences between the estimate and actual number (Grant, 2016). Practicing mathematical skills in the garden engages the students with hands-on interactions and provides opportunities to observe how processes work (Grant). The comparative study and survey conducted by Lieberman and Hoody (1988), revealed an increase in math scores relating to mathematic achievement. The results from the 40 schools found that students engaged in EIC programming showed a 73 percent increase in understanding of mathematical concepts and content, 92 percent better mastery of math skills, and 89 percent more enthusiasm for studying math when compared to the traditional students.

Reading and writing are two important classroom basics - mastery of these skills provides the opportunity for students to succeed. Relating language arts exercises to the garden can be a useful tool to promote student reading and writing mastery. An example activity of language arts in the garden involves students' journaling about what they see, think, and feel, while in the garden environment (Grant, 2016). Students also can gain experience in research by exploring the growing habits of the school garden plants and creating a planting schedule based 
on the information found. Mathematics and language arts are not the only subjects included in the school garden curriculum and content and lesson focus varies vastly between curriculums.

Sciences. Science content is the most common core subject taught in garden-based learning (Graham, Beall, Lussier, McLaughlin, \& Zidenberg-Cherr, 2005). In a study examining the use of school gardens in academic instruction via survey, California principals $(\mathrm{N}=9805)$, reported on their perceived effectiveness of the school garden at enhancing skills and subject matter taught in schools (Zidenberg-Cherr, 2005). Ninety-five percent (95\%) of the respondents $(n=2381)$ rated science as the most frequently taught subject in the garden while sixty-nine percent $(69 \%)$ regarded the garden to be moderate to very effective at enhancing science knowledge. Although the study aimed to show that science taught in the garden can lead to student achievement, the authors suggested that there is a need for curriculum materials and teacher training for this type of experiential learning.

Prior research has indicated that integrating a gardening program into the curriculum throughout the course of one school year could increase students' science scores, especially among lowincome schools (Klemmer, Waliczek, \& Zajicek, 2005; Wells, Myers, Todd, Barale, Gaolach, Ferenz, Aitken, Henderson, Tse, Pattison, Taylor, Connerly, Carson, Gensemer, Franz, \& Falk, 2015).

In their quasi-experimental study, Klemmer et al (2005) examined the effectiveness of science achievement of third, fourth, and fifth-grade elementary students ( $n=647)$ using gardenbased learning activities as part of their science curriculum. Science achievement test instruments were developed by the researcher and incorporated the science Texas Essential Knowledge and Skills (TEKS) state-mandated content. Teachers were asked to implement the curriculum to the fullest extent possible throughout the entire school term of 2000-01. The final 
sample consisted of seven differing schools, with 27 classes in the experimental group $(\mathrm{n}=453)$ and 13 classes in the control group $(n=194)$. Students in the experimental group scored 5.6 points higher on the science achievement test compared to the control group $(\mathrm{p}<0.001)$. This result is consistent with research indicating that students' knowledge levels are increased through the use of hands-on, experiential activities (Freedman, 1997; Keeves \& Morganstern, 1992; Solter, 1997; \& Stohr-Hunt, 1996). Lesson time spent in the garden can result in better achievement scores when compared to students that are given little or no time to learn in the garden.

In their quasi-experimental study, Smith and Motsenbocker (2005) quantified the effects of a school garden and garden curriculum on the science achievement of fifth grade students $(\mathrm{N}=119)$ at three inner-city, elementary schools. For each experimental class $(n=62)$, there was a corresponding control class $(\mathrm{n}=57)$ for every school and grade. A forty-question, science achievement pre-and post-test was analyzed for differences in both the experimental and control classes to determine if the garden program influenced test scores. The results showed that science achievement was significantly different $(\mathrm{p}<0.0167)$ between the experimental classes' pretest and posttest scores. There was no significant difference between the pretest and posttest scores of the control classes, and there was no significant difference found between the experimental and control classes due to treatment. Positive results have been seen concerning science achievement coupled with the use of garden-enhanced exposure, however the authors suggest that more research needs to be conducted in this area before it can be said that gardens definitively increase science achievement (Smith \& Motsenbocker, 2005).

Curricula such as the Junior Master Gardener Program have established a tie to national standards. There is a large body of knowledge that suggests that science education can be 
improved through the use of an applied, hands-on curriculum. If the garden can be "marketed" as a learning laboratory in a credible fashion, similar to the Life Lab Program based in California, then the emergence of school gardens could have a significant impact on elementary science education.

Attitudes and behaviors. Few studies have examined the possible shifts in student attitudes that may occur as results of experiences in school gardens (Fisher-Maltese \& Zimmerman, 2015). A mixed methods case study of a garden-based, science curriculum, conducted by Fisher-Maltese and Zimmerman (2015) took place in four second-grade classrooms in central New Jersey. Sixty-six-second graders $(n=66)$ participated in the study, along with four teachers, and one principal $(n=71)$. The aim of this study "sought to demonstrate the value of garden-based learning with a focus on measuring learning, typically associated with the informal learning environment" (p. 51). The aim of the study was not to change or alter students' attitudes towards the current environment but to examine the existing environmental attitudes. Using a pre/post survey on environmental attitudes, the results indicated little to no change in students' attitudes.

The Stephanie Alexander Kitchen Garden Program was implemented with children ages eight to twelve $(n=342)$ in Australian primary schools. The focus of this study was to examine the impacts of the kitchen garden program on the social and learning environment of the schools. Using a mixed-methods approach, the researchers discussed that the results demonstrated strong evidence that participation in their program was an "overwhelmingly positive experience for children and school communities" (Block, Gibbs, Staiger, Gold, Johnson, Macfarlane, \& Townsend, 2012, p. 437). The researchers also discussed positive social impacts included an increase in student engagement and confidence at school, improvements to the school learning 
environment, and strengthening of social connections between the schools and the wider communities (Block, et al., 2012). However, it was suggested that larger sample sizes be used in future research to statistically give evidence to the effect on students' attitudes and behaviors.

In a study conducted on beliefs and attitudes by Childs (2011), the objectives were to explore middle school students' self-efficacy towards academic ability, specifically towards science, and to describe student attitudes towards plants and gardening. Childs (2011) used a descriptive survey to assess the level to which middle school students, from an existing school garden program, agree or disagree with statements about their behaviors and attitudes. Results of the study showed that the students recognized the importance and impact of growing and eating food in school and family gardens.

Children's health and nutrition. Research consistently shows that the majority of American children do not consume diets that meet the recommendations of the Dietary Guidelines for Americans, nor do they achieve adequate levels of daily physical activity (Story, Nanney, \& Shwartz, 2009; USDA, 2015). Epidemiological evidence suggests that a diet high in fruits and vegetables can help protect the body against cardiovascular disease, type 2 diabetes, and some types of cancer - about half of all American adults have one or more of these preventable, diet-related chronic diseases (Block, 1982; Joshipura, Ascherio, Manson, Stampfer, Rimm, \& Speizer, 1999; National Research Council, 1989; Steinmetz \& Potter, 1991, USDA, 2015). The 2015-2020 Dietary Guidelines for Americans recommend that individuals who are age 2 or older consume a minimum of five servings of fruits and vegetables each day or fill half of their plate (National Research Council, 1989; United States Department of Agriculture [USDA], 1992, 2000). Current dietary habits of children have become the focus of behavior interventions and related research because the food intake of the age group, as mentioned above, 
does not align with national recommendations (USDA, 2015). In their longitudinal study on snacking among U.S. children, Peirnas and Popkin (2010) revealed that children's snacking trends are moving toward three snacks per day, consisting of more than 27 percent of their daily caloric intake (mostly high fat, high sugar content foods). School gardening programs have the potential to improve/have a positive impact on children's nutritional and health status (Block, et al., 2012; Ozer, 2007).

Nutrition education. The use of school gardens as a nutrition education tool is becoming more prevalent with the rising concern for childhood obesity. School gardens are being utilized as a resource for teaching youth about nutrition and healthy lifestyles through fruit and vegetable production, particularly in California with the Garden in Every School initiative (California Department of Education, 2007; Lineberger \& Zajicek, 2000; Graham \& Zidenberg-Cherr, 2005). Garden-enhanced nutrition programs in schools that incorporate hands-on garden experience, seem to increase the number of fruits and vegetables children eat on a daily basis, particularly in vegetable consumption and healthy snack choices (Lineberger \& Zajicek, 2000; Morris, Briggs, \& Zidenberg-Cherr, 2000; Morris \& Zidenberg-Cherr, 2002; Koch et al., 2005). Many studies focus on the effects of gardening on improved achievement and attitudes toward a food group, such as fruits and vegetables.

Two similar studies found that gardening programs were able to significantly impact students with lower vegetable preference pre-test scores more so than students with higher vegetable preference pre-test scores (Lineberger \& Zajicek, 2000; Koch et al., 2005) Students with low scores have more room to improve their attitudes about vegetables than students who are already familiar with many vegetables. Lineberger and Zajicek (2000) also commented on the ideal age to implement garden-enhanced learning to achieve reliable transformation of 
attitudes; younger students are typically more acceptable and flexible at accepting school gardens as a new learning resource beyond the classroom (Childs, 2011).

A study conducted by Morgan, Warren, Lubans, Saunders, Quick, and Collins (2010) investigated the impact of school garden nutrition education on two elementary schools, grades 5 and 6, $(\mathrm{n}=127)$ in New South Wales, Australia. The quasi-experimental, 10-week intervention explored children's fruit and vegetable knowledge, vegetable preferences, fruit and vegetable consumption, and quality of school life. Those mentioned above were measured at baseline and four-month follow-up. An intervention with nutrition education and garden (NE\&G), NE only and control groups were utilized for the study. The results of this study showed that there was a significant difference between the different groups (NE\&G and NE) and their overall willingness to taste vegetables $(\mathrm{p}<0.001)$ and overall taste ratings of vegetables $(\mathrm{p}<0.001)$. Other ratings were listed in the article, but the overall impact of school gardens showed to be positive with the primary-school students' and their willingness to taste vegetables. Morgan, et al., (2010) encourage the inclusion of more comprehensive strategies to increase students vegetable intake. Schools overwhelmingly have proven to be prime locations for noticing the increasing weight trends in youth, as they are also prime locations for educating and assisting youth in healthy decisions via nutrition programs (Centers for Disease Control [CDC], 2010).

Children's body mass index. A study conducted by Utter, Denny, and Dyson (2015), explored the impact of school gardens on students eating behaviors, physical activity, and body mass index (BMI). The researchers studied New Zealand secondary school students $(\mathrm{n}=8,500)$ aiming to determine if school gardens could be the missing link between household poverty and adolescent BMI. Data was collected from a national study of the health and well-being of this age group, and multilevel regression models were used to find associations between the school 
garden and student nutrition behaviors, physical activity and measured BMI (Utter, Denny, \& Dyson, 2015). The results of the study included that almost half of the secondary schools had a fruit and or vegetable garden for the students to take part in, although not significant, school gardens were associated with lower student BMI $(\mathrm{p}=0.01)$ and lower prevalence of overweight $(\mathrm{p}<0.01)$. Utter, Denny, and Dyson (2015) concluded that school garden do have a positive effect on student health, but future research needs to explore how they are implemented and how to extend the benefits beyond the school community.

National organizations recognize the importance of participation in PA for the overall well-being of children and have responded with parents' and educators' recommendations to ensure appropriate and ample PA opportunities are provided both at home and in the school setting (U.S. Department of Health and Human Services [USDHHS], 2012; U.S. White House Task Force on Childhood Obesity, 2010). Schools offer many opportunities to develop strategies to prevent obesity by creating environments in which children eat healthfully and regularly engage in PA (Story, Nanney, \& Shwartz, 2009; Vander Ploeg, Maximova, McGavock, Davis, \& Veugelers, 2014).

A descriptive case study conducted by Beery, Adatia, Segantin, and Skaer (2013) examined two schools in Johannesburg, South Africa and the highlights and outcomes of the school's food garden projects. The gardens were implemented as an ecological health promotion intervention, food security and urban greening initiative, and as a tool for health promotion among young people. The University of Westminster conducted a year-long evaluation of the children's diet and eating patterns to assess their macro- and micronutrient intake.

The priorities established for the garden included ensuring that the garden would be organic, growing the food for the school, the school would be responsible for maintaining the 
garden, and teachers, learners, caretakers, and other community members were encouraged to participate. An environmental education practitioner worked with the teachers to make lessons geared toward the gardens and to demonstrate to the teachers that the garden can be used as a learning resource for all subjects, not just natural science (Berry, et al., 2013). Eating patterns and nutrient intake was recorded via a 24-hour food recall survey and included 68 children in each school $(n=136)$. The results of the study focused on the relevance of the teaching session to the learning program, the principal's reflection of the process, and the children's nutrition assessment.

The survey of nutritional assessment showed that even after the intervention, the sample's energy intake $(1,718 \mathrm{kcal})$ remained far below the Food and Agriculture Organization of the United Nations estimates for energy requirements $(2,011 \mathrm{kcal})$. The samples micronutrient intake proved to be much lower for vitamin A, C, calcium, and zinc (Beery, et al., 2013). The authors do conclude that assessment of the intervention should be completed after three years or more to fully assess sustainability of the garden and changes to diets.

Children's physical activity during the school day. The Center for Disease Control reports indicates that childhood obesity has been steadily increasing since 1970 . Elementary to high school aged youth have obesity rates upwards of twenty percent (Ogden \& Carroll, 2010). The nation-wide cry out for help and intervention for the youth of America has led to innovative strategies to reduce sedentary behavior and increase PA during childhood with the hopes of curbing the obesity epidemic (Elder, 1998; Park, Lee, Lee, Son \& Shoemaker, 2013). Children’s physical activity behaviors are influenced by many sectors of society, including family, community organizations, schools, etc. It has been argued that the school-age years are a critical time for developing diet and physical activity habits that have been shown to track into 
adulthood (John, Gunter, Jackson, \& Manore, 2015). Since children are required to spend at least ten consecutive years in the school system, schools become a predominant place and have enormous potential to reach most children and should play an important role in providing children with the knowledge, skills, and opportunities to be physically active due to the significant amount of time children spend at school on a daily basis (Pate, Davis, Robinson, Stone, McKenzie, \& Young, 2006; Mygind, 2007; Park, Lee, Lee, Son, \& Shoemaker, 2013). Through schools, children can gain the knowledge and opportunities to be physically active throughout the school environment and school day, and families can learn how to reinforce active lifestyles (American Alliance for Health Physical Education Recreation and Dance [AAHPERD], 2013; Bernstein, 2015). However, since the enactment of No Child Left Behind in 2001, schools have cut time from traditional school PA opportunities like physical education (PE) classes and recess to accommodate the additional focus on English, Language Arts, and Math (McMurrer, 2007; Bernstein, 2015). Consequently, to encourage the role of schools in helping children achieve 60 minutes of activity time daily, many studies have suggested that additional PA opportunities should be offered by the school - beyond traditional venues (Carson, 2012; Carson, Castelli, Beighle, \& Erwin, 2014; Wells \& Myers, 2014).

Children's physical activity in the garden. Wells, Myers, and Henderson (2014) conducted a two-year, randomized controlled trial examining the effects of school gardens on children's overall physical activity and sedentary behaviors. The study addressed three research questions about the effect of school gardens on children's physical activity measured by a selfreport survey (the Girls Health Enrichment Multi-site Activity Questionnaire), accelerometers, and direct observations. Fourth and fifth-grade students (ages 8-12) in New York State schools were enrolled in the intervention study. Schools were randomly assigned to receive the garden 
intervention or to be in the control group that received the garden and curriculum at the end of the study. Ten $(n=10)$ schools were randomly assigned to the intervention group, and nine $(n=9)$ schools were assigned to the control group. Children participating in the study wore accelerometers during the entire school day and their data was recorded at the end of the day. The accelerometer data showed the percentage of time spent being sedentary, light PA, moderate PA, vigorous PA, and moderate-vigorous PA. This procedure was used during the four waves of intervention, for three days at a time. To measure the student's movements during a garden lesson (compared to an indoor lesson), Myers and Wells (2015) created the Physical Activity Research and Assessment tool for Garden Observation (PARAGON). Based on the Behaviors of Eating and Activity for Children's Health (BEACHES), PARAGON relied on five primary PA codes: lying, sitting, standing, walking, and vigorous activity (McKenzie, Sallis, Nader, Patterson, Rupp, Akins, Buono, \& Nelson, 1991; Rowe, Schuldeisz, \& VanderMars, 2003). An analysis of the accelerometry data indicated that children at the intervention schools with the garden, increased the percentage of their moderate PA when compared to the control schools. Also, the data from the direct observations showed that the children move more and engage in a variety of postures during the garden-based lesson when compared to the indoor classroom lesson; standing (53\% in the garden to $10 \%$ in the classroom), walking (14\% in the garden to $0 \%$ in the classroom), sitting (15\% in the garden to $84 \%$ in the classroom), and kneeling (9\% in the garden to $0 \%$ in the classroom). Overall, the study reported that schools with gardens reduce sedentary behaviors and increase moderate PA during the school day (Wells, Myers, \& Henderson, 2014). The authors suggested that future research should examine the outdoors as a mediator to children's physical activity and the effects of school gardens on educational outcomes. Multiple school garden studies, comparing PA levels of indoor and 
outdoor lessons, clearly state that children's PA levels while outdoors are drastically higher when compared to children's PA levels during indoor lessons.

Indoor and outdoor lessons. In Mygind's (2007) case study comparing children's activity levels at school and in an outdoor environment, it was found that the outdoor environment is conducive to inductive learning methods, which include more PA, as compared to the normal classroom situation. Mygind discussed that the "outdoor environment should not replace the traditional classroom setting, but should rather be complementary, as both learning contexts are important to children's needs" (2009, p. 174). It was also noted that two overweight children were two and three times more active on the forest day compared to a normal school day.

In a study completed on green school grounds as sites for promoting PA (Dyment \& Bell, 2007), one of the findings addressed the importance of providing children with enjoyable, noncompetitive opportunities as well as opportunities to integrate PA into their daily lives especially children struggling with being overweight or obese. The majority of survey participants (84\%) report that since "greening," their school ground encourages exploration of the natural world and PA promotion. They describe, for example, how children are involved in 'chasing butterflies', 'exploring for rocks and insects', 'looking at plants', 'bug watching' and 'animal catching and releasing'. Through their gardening efforts children were also 'digging', 'watering', 'weeding', 'planting', 'mulching', 'harvesting', 'pruning', 'raking', 'composting', 'lifting' and 'cleaning' - all physical activities which tangibly and meaningfully engage them in their environment (Dyment \& Bell, 2007). Other studies reported that the relationship between the design of school grounds and student behavior seems clear: outdoor time become much more peaceful and harmonious when play spaces are diversified (Moore \& Wong, 1997). 
Learning should not stop at school subjects - leadership, communication, nutrition and environmental education can also be taught in the garden (Smith, 2003). For richer data, DeMarco, et al., (1999) also interviewed teachers $(\mathrm{N}=28)$ from the 322 surveyed schools. The teachers were asked to identify five school gardening factors that were essential to the successful use of gardening in the curricula. School gardening was incorporated into most educational subject areas, demonstrating the ability of teachers to use gardening across the curriculum. Survey responses indicated that gardening was used as a teaching tool with children in all age levels found in the elementary school environment. Teachers' perceptions of school gardening were reflected by their teaching goals when using gardening in the curriculum and comments are written to clarify goals. The majority of the surveyed teachers $(91.5 \%)$ indicated that they used gardening for students' academic learning. Teachers also indicated that they used gardening as a forum for expanding the students learning through social $(83.1 \%)$, recreational $(61.9 \%)$ and therapeutic $(51.7 \%)$ experiences. Social development was enhanced by introducing students to such topics as community service, diversity in human culture, and environmental stewardship. Recreational uses included activities such as forming a gardening club, beautifying the school, and having fun. Therapeutic goals were reflected by comments about the motivational, emotional, and enriching qualities of gardening.

In a self-administered Internet survey, California school principals $(n=4,194)$ answered questions regarding school garden practices, attitudes associated with the garden, and perceptions of barriers to having and using school gardens in academic instruction. The results of the survey $(\mathrm{p}<.05)$ showed that teachers taught science 65 percent of the time and nutrition only 47 percent of the time spent in the garden. This same survey reports that most of the principals $(69 \%)$ found the garden to be a moderate to very effective tool for enhancing science 
skills. Overall, school gardens in California appeared to be used mostly by elementary schools to enhance academic instruction with a positive outlook from school principals.

The teachers also commented on their goals in using gardening with their classes. In comments written to clarify these goals, 91.5 percent of surveyed teachers specified that they used gardening for students' academic learning. Approximately 83 percent of teachers indicated that they used gardening as a forum for expanding the students' learning through social experiences, 61.9 percent expressed that they used the garden for expanding the students' learning through recreational experiences, and 51.7 percent said they used gardening to expand students' learning through therapeutic experiences (DeMarco, Relf, \& McDaniel, 1999). Jorgenson (2013) conducted an interesting qualitative study with three $(n=3)$ primary school teachers working in the Midwest. All three of the teachers have worked at a school that possessed a massive garden, implemented ten years ago. Each teacher was interviewed twice and was asked to share their experiences of incorporating a school garden into their regular teaching practices. Other questions related to family, education, and their life history. Jorgenson (2013) found through the interviews that there is a complex combination of internal processes and products that serve to rationalize teachers' regular use of a school garden. Nostalgia appeared to be the big finding within the study. The teachers seemed to be driven to participate in the school garden due to their experience of being outdoors as a child. "For primary teachers such as Laura, Meredith, and Clare, recollecting a better past, a time that offered children opportunities and experiences that no longer exist, may represent a way of sustaining their identities in an educational institution" (p.132). Nostalgia may serve as a deterrent for some teachers who resist the school garden experience, however for most teachers, working in the school garden brings back positive memories. "The school garden could become a nostalgic site, 
a place where childhood memories become entangled with collective memories of a pastoral ideal" (p.132).

Family and community involvement. Okirir, Matisiko, and Oonyu (2011) argue that school gardening programming can serve as a platform for reaching families and communities. Despite the benefits of parental involvement, parents and teachers alike have reported barriers to partnerships (e.g., Davies, 1993; Epstein, 1986; Lightfoot, 1981; Moles, 1993). Parents identified barriers have included low sense of efficacy for helping children learn, the absence of requests and invitations from the school, and self-perceptions of inadequate skills and knowledge (e.g., Comer \& Haynes, 1991; Epstein, 1986; Epstein \& Dauber, 1991; Hoover, Dempsey, \& Sandler, 1995, 1997). Barriers from teachers perspectives include low teaching efficacy, negative experiences with parents, uncertainty about working with diverse families, and inadequate school support for involvement efforts (e.g., Griffith, 1996; Hoover-Dempsey, et al., 1992; Midkiff \& Lawler-Prince, 1992).

\section{The Garden Curriculum}

Pascoe and Wyatt-Smith (2013) conducted a qualitative research study on the potential of school gardens as an effective middle years learning environment, teaching curriculum literacies in a cross-curricular manner. The study was conducted due to the low scores of the literacy learning outcomes of Queensland, Australia's primary school students when compared to those in surrounding areas and other countries. Observations and interviews were used for data collection methods. Two Queensland State primary schools were included in the project in which both had different types of school garden programs, differing in size (600 and 300), and in socio-economic status. This study examined cross-curricular activities that the teachers used based in the garden from their developed resource, Tools for Teachers (Pascoe \& Wyatt-Smith, 
2013). Tools for Teachers provides learning units, lessons, activities, and resources that link with the Kitchen Garden Program and the Australian Curriculum which includes science, math, English, history, geography, and ICT. Some classroom activities included differing locations such as the classroom, garden, and kitchen. This article provides ideas and resources for current programs and teachers. Both schools, after implementation of the current garden program, showed improved results in literacy and numeracy and some other areas dramatically, except grammar and punctuation \& spelling (Pascoe \& Wyatt-Smith, 2013).

I used to fear math, but working in the garden has changed that. I have a higher grade now. When we made salsa, we sold 150 pints at three dollars a pint and made fourhundred-and fifty-dollars. The best part was when we got to collect and count the money (Student from Turner Elementary, CSGN, 2015).

Interviews with both students and teachers showed positive attitudes toward implementing gardening into math, English, and other subjects and gave insight to future implementation of programs. 


\section{References}

Akins, R. B., Tolson, H., \& Cole, B. R. (2005). Stability of response characteristics of a Delphi panel: application of bootstrap data expansion. BMC medical research methodology, 5(1), 37.

Alvior, M. (2015). The meaning and importance of curriculum development. Retrieved August 15, 2016, from https://www.linkedin.com/pulse/meaning-importance-curriculumdevelopment-dr-mary-alvior.

American Alliance for Health, Physical Education, Recreation and Dance [AAHPERD]. (2013). Comprehensive school physical activity programs: helping students achieve 60 minutes of physical activity each day [Position statement]. Reston, VA: Author

American Nutrition Association. (2010). USDA defines food deserts. Nutrition Digest, 37(2).

Armstrong, D. (2000). A survey of community gardens in upstate New York: Implications for health promotion and community development. Health \& Place, 6(4), 319-327.

Arnold, S., Warner, J.W., \& Osborne, E.W. (2006). Experiential learning in secondary agricultural education classrooms. Journal of Southern Agricultural Research, 56(1).

Bailey, L. H. (1904). The nature-study idea: Being an interpretation of the new school-movement to put the child in sympathy with nature. New York: Doubleday, Page \& Company.

Baranowski, T., Baranowski, J., \& Cullen, K. (2003). The fun, food, and fitness project (FFFP): the Baylor GEMS pilot study. Ethnicity Distribution, 13(1), 1-30.

Basch, C.E., Zybert, P., \& Shea, S. (1994). 5-A-DAY: Dietary behavior and the fruit and vegetable intake of Latino children. American Journal of Public Health, 84, 814-818.

Bilbao, P.P., Lucido, P.I., Iringan, T.C., \& Javiar, J.B. (2008). Curriculum development. Philippines: Lorimar Publishing, Inc. 
Blair, D. (2009). The child in the garden: An evaluative review of the benefits of school gardening. The Journal of Environmental Education, 40(2), 15-38.

Block, K., Gibbs, L., Staiger, P. K., Gold, L., Johnson, B., Macfarlane, S., \& Townsend, M. (2012). Growing Community: The Impact of the Stephanie Alexander Kitchen Garden Program on the Social and Learning Environment in Primary Schools. Health Education \& Behavior, 39(4), 419-432.

Bohnert, A., Fredricks, J., \& Randall, E. (2010). Capturing unique dimensions of youth organized activity involvement: Theoretical and methodological considerations. Review of Educational Research, 80(4), 576-610.

Bottoms, G., \& Schmidt-Davis, J. (2010). The Three Essentials: Improving Schools Requires District Vision, District and State Support, and Principal Leadership. Southern Regional Education Board (SREB).

Brustad, R.J. (1996). Attraction to physical activity in urban schoolchildren: Parental socialization and gender influence. Research Quarterly for Exercise and Sport, 67(3).

Burros, M. (2009). Obamas to plant vegetable garden at White House. New York Times, 20.

California Department of Education. (2005). Catalogue listing of publications. Retrieved July 8, 2016, from http://www.cde.ca.gov/re/pn/rc/ap/pubcat.aspx

Canadian Institute for Health Information [CIHI]. (2006). Improving the Health of Canadians. Ottawa, Canada: Canadian Institute for Health Information.

Carson, R. (2012). Certification and duties of a director of physical activity. Journal of Physical Education, Recreation \& Dance, 83(6), 16-29. 
Carson, R., Castelli, D., Beighle, A., \& Erwin, H. (2014). School-Based Physical Activity Promotion: A Conceptual Framework for Research and Practice. Childhood Obesity. 10(2).

Castro, M. L. (2010). School gardens: Academic effects on low socioeconomic first grade students. (Unpublished).

Centers for Disease Control and Prevention, (2010). Nutrition and Physical Activity Program to Prevent Obesity and other Chronic Diseases. Obesity Among Low-Income Preschool Children. Centers for Disease Control and Prevention, Atlanta, GA

Centers for Disease Control and Prevention, (2011). School health guidelines to promote healthy eating and physical activity. MMWR. Atlanta GA, CD.C. \& US Department of Health and Human Services 60 (5).

Centers for Disease Control and Prevention, (2013). Comprehensive school physical activity programs: A guide for schools. US Department of Health and Human Services: Atlanta, GA.

Clayton, M.J. (1997). Delphi: A technique to harness expert opinion for critical decision-making tasks in education. Education Psychology, 17, 373-387.

Hsu, C. C., \& Sandford, B. A. (2007). The Delphi technique: making sense of consensus. Practical assessment, research \& evaluation, 12(10), 1-8.

Dalkey, N., \& Helmer, O. (1963). An experimental application of the Delphi method to the use of experts, Management Science, 9(3), 458-467.

Danks, S. G. (2010). Asphalt to ecosystems: Design ideas for schoolyard transformation. New Village Press. 
Danks, S. G. (2014). Living schoolyards for California: Exciting new state resolution will bring more children outside at public schools. Children and Nature Network,

Delbecq, A.L., Van de Ven, A.H., \& Gustafson, D.H. (1975). Group Techniques for Program Planning: A Guide to Nominal Group and Delphi Processes, Scott, Foresman and Company, Glenview, Illinois.

DeMarco, L. W., Relf, D., \& McDaniel, A. (1999). Integrating gardening into the elementary school curriculum. Hort Technology, 9(2), 276-281.

Dennison, B.A., Rockwell, H.L., \& Baker, S.L. (1998). Fruit and vegetable intake in young children. Journal of the American College of Nutrition, 17, 371-378.

Desmond, D., Grieshop, J., \& Subramaniam, A. (2002). Revisiting garden based learning in basic education: Philosophical roots, historical foundations, best practices and products, impacts, outcomes, and future directions. Food and Agriculture Organization, 59.

Desmond, D., Grieshop, J., \& Subramaniam, A. (2004). Revisiting garden-based learning in basic education. Food and Agriculture Organization of the United Nations.

Dewey, J. (1915). Schools of tomorrow. New York: E. P. Dutton

Dirks, A. E., \& Orvis, K. (2005). An evaluation of the junior master gardener program in third grade classrooms. HortTechnology, 15, 443-447.

Doerfler, H.A. (2011). Using School Gardens as a Vehicle for Health Promotion for Elementary School Youth: A Review of the Literature.

Douglass, Y.P., \& Habib, D. (2014). Seeds of Solidarity: Grow Food Everywhere ChilD.C.are Provider Garden Program 2014 Summary of Successes, Results from Research, and Outreach Outcomes. 
Draper, C., \& Freedman, D. (2010). Review and Analysis of the Benefits, Purposes, and Motivations Associated with Community Gardening in the United States. Journal of Community Practice, 18(4), 458-492.

England, N. (2009). Childhood and nature: A survey on changing relationships with nature across generations. Cambridgeshire: Natural England.

Evans, A., Ranjit, N., Fair, C. N., Jennings, R., \& Warren, J. L. (2016). Previous gardening experience and gardening enjoyment is related to vegetable preferences and consumption among low-income elementary school children. Journal of Nutrition Education and Behavior, 48(9), 618-624..

Evanston Environmental Association. (2016). Schools are Gardening in Evanston. Retrieved, October 7, 2016, from http://evanstonenvironment.org/sage.

Faddegon, P A. (2005). The kids growing food school gardening program: Agricultural literacy and other educational outcomes. Doctoral dissertation, Cornell University, Ithaca, NY.

Fiege, A. (October 14, 2010). A Showcase School Garden in D.C.. Retrieved from http://www.smithsonianmag.com/arts-culture/a-showcase-school-garden-in-D.C.$\underline{102235322 / .}$.

Fischer, R.G. (1978). The Delphi method: a description, review and criticism. Journal of Academic Librariansh, 4(2):64-70.

Fisher-Maltese, C., \& Zimmerman, T. D. (2015). A Garden-Based Approach to Teaching Life Science Produces Shifts in Students' Attitudes toward the Environment. International Journal of Environmental and Science Education, 10(1), 51-66.

Growing Minds. (2016). Farm to School Lesson Plans. Retrieved, August 15, 2016, from http://growing-minds.org/lesson-plans-landing-page/. 
Habib, D., \& Doherty, K. (2007). Beyond the Garden: Impacts of a School Garden Program on 3rd and 4th Graders. Seeds of Solidarity.

Halpern, R. (2002). A different kind of child development institution: The history of after-school programs for low-income children. Teachers College Record, 104(2), 178-211.

Hayden-Smith, R. (2014). Sowing the Seeds of Victory: American Gardening Programs of World War I. McFarland.

Higgins, A. (2016, December 7). As school gardens spread, so do the teaching moments. The Washington Post. Retrieved February 1, 2017, from https://www.washingtonpost.com/lifestyle/home/as-school-gardens-spread-so-do-theteaching-moments/2016/12/06/98e864f0-b8bf-11e6-b994$\underline{\mathrm{f} 45 \mathrm{a} 208 \mathrm{f} 7 \mathrm{a} 73 \text { story.html?utm_term }=.4 \mathrm{~b} 95 \mathrm{~b} 1 \mathrm{e} 586 \mathrm{ac}}$

Huckfeldt, V.E. \& Judd, R.C. (1974). Issues in large scale Delphi studies, Technol. Forecast. Soc. Change, 7, 175-184.

Joshipura, K.J., Ascherio, A., Manson, J.E., Stampfer, M.J., Rimm, E.B., \& Speizer, F.E. (1999). Fruit and vegetable intake in relation to risk of ischemic stroke. Journal of the American Medical Association, 282, 1,233-1,239.

Keeves, J. P., \& Morgenstern, C. (1970). Attitudes towards science: Measures and effects. The IEA Study of Science III: Changes in science education and achievement, 1984, 122-140.

Klemmer, C.D., Waliczek, T.M. \& Zajicek, J.M. (2005). Growing Minds: The Effect of a School Gardening Program on the Science Achievement of Elementary Students. HortTechnology. 15(3): 448-452.

Kohlstedt, S. G. (2005). Nature, not books: Scientists and the origins of nature-study movement in the 1890s. Isis, 96, 324-352. 
Krebs-Smith, S.M., Cook, A., Subar, A.F., Cleveland, L., Friday, J., \& Kahle, L.L. (1996). Fruit and vegetable intakes of children and adolescents in the United States. Archives of Pediatrics and Adolescent Medicine, 150, 81-86.

Lacey, A., \& Luff, D. (2001). Qualitative Data Analysis, Trent Research and Development Support Unit, Sheffield.

Larson, T., Samdal, O., \& Tjomsland, H. (2012). Physical Activity in Schools: A qualitative case study of eight Norwegian schools' experiences with the implementation of a national policy. Health Education Journal, 113(1), 52-63.

Let's Move! Let's Move! Active Schools. (2014). Available at http://lets moveschools.org

LifeLab. (2006). Garden based learning that promotes a sustainable future. Retrieved July 31, 2006, from http://www.lifelab.org/about/index.html

Lohman, J. S. (2010). Comparing no child left behind and race to the top. Connecticut General Assembly, Office of Legislative Research.

McKenzie, T., Sallis, J., Nader, P., Patterson, T., Rupp, J., Atkins, C., Buono, M., \& Nelson, J. (1991). BEACHES: an observational system for assessing children's eating and physical activity behaviors and associated events. Journal of Applied Behavior Analysis, 24(1):141-151.

McInturff, S. 2009. The Delphi Method. Forecasting and Futurism Newsletter 1: 10-15. Nov.5, 2012.

Morgan, P.J., Warren, J.M., Lubans, D.R., Saunders, K.L., Quick, G.I., \& Collins, C.E. (2010). The impact of nutrition education with and without a school garden on knowledge, vegetable intake and preferences and quality of school life among primary-school students. Public health nutrition, 13(11), 1931. 
Montessori, M. (1912). The absorbent mind. Translated from the Italian by Claude A.

Claremont. New York: Dell Pub. Co.

Morris, J., Briggs, M., \& Zidenberg-Cherr, S. (2000). School-based gardens can teach kids healthier eating habits. California Agriculture, 54(5), 40-46.

Morris, J. L., \& Zidenberg-Cherr, S. (2002). Garden-enhanced nutrition education curriculum improves fourth-grade school children's knowledge of nutrition and preferences for some vegetables. Journal of American Dietetic Association, 102(1), 91-93.

Morton, L. W., \& Blanchard, T. C. (2007). Starved for access: life in rural America's food deserts. Rural Realities, 1(4), 1-10

Munoz, K.A., Krebs-Smith, S.M., Ballard-Barbash, R., \& Cleveland, L.E. (1997). Food intakes of U.S. children and adolescents compared with recommendations. Pediatrics, 100, 323329.

National Association for Sport and Physical Education, (2004). Physical Activity for Children: A Statement of Guidelines for Children Ages 5-12. National Association for Sport and Physical Education, Reston, VA.

National Association for Sport and Physical Education. (2008). Comprehensive school physical activity programs. Reston, VA: Author. [Position statement].

National Gardening Association. (2006). About National Gardening Association. Retrieved Septemeber 1, 2016, http://garden.org/search/index.php?q=curriculum\&button.

Newmann, F. M., \& Associates. (1996). In F. M. Newmann (Ed.), Authentic achievement: Restructuring schools for intellectual quality, (pp. 1-16). San Francisco, CA: Jossey-Bass. 
Office of the State Superintendent of Education. (2013). D.C. School Garden-Based Curriculum Recommendations. Retrieved September 1, 2016, from http://osse.D.C..gov/publication/D.C.-school-garden-based-curriculum-recommendations.

Ogden, C., Carroll, M., Curtin, L., Lamb, M., Flegal, K., (2010). Prevalence of high body mass index in US children and adolescents, 2007-2008. Journal of American Medical Association, 303 (3), 242-249.

Ogden, C.L, Carroll, M., Kit, B.K., \& Flegal, K.M. (2014). Prevalence of Childhood and Adult Obesity in the United States, 2011-2012. Journal of American Medical Association, 311(8):806-814.

Okiror, J. J., Matsiko, B. F., \& Oonyu, J. (2011). Just How Much Can School Pupils Learn from School Gardening? A Study of Two Supervised Agricultural Experience Approaches in Uganda. Journal of Agricultural Education, 52(2), 24-35.

Okoli, C. \& Pawlowski, S.D. (2004). The Delphi method as a research tool: An example, design considerations and applications. Information \& Management, 42: 15-29.

Ozer, E. J. (2007). The effects of school gardens on students and schools: Conceptualization and considerations for maximizing healthy development. Health Education \& Behavior: The Official Publication of the Society for Public Health Education, 34(6), 846-863.

Pate, R.R., Davis, M.G., Robinson, T.N., Stone, E.J., McKenzie, T.L., \& Young, J.C. (2006). Promoting physical activity in children and youth a leadership role for schools: A scientific statement from the American Heart Association Council on Nutrition, Physical Activity, and Metabolism (Physical Activity Committee) in collaboration with the councils on Cardiovascular Disease in the Young and Cardiovascular Nursing. Circulation, 114, 1214-1224. 
Pate, R.R., \& O’Neill, J.R. (2009). After-school interventions to increase physical activity among youth. British Journal of Sports Medicine, 43(1), 14-18.

Peterson, K. E., \& Fox, M. K. (2007). Addressing the epidemic of childhood obesity through School-Based interventions: What has been done and where do we go from here? The Journal of Law, Medicine \& Ethics, 35(1), 113-130.

Pothukuchi, K. (2004). Hortaliza: A youth “nutrition garden” in southwest Detroit. Children Youth and Environments, 14(2), 124-155.

Ray, R., Fisher, D. R., \& Fisher-Maltese, C. (2016). SCHOOL GARDENS IN THE CITY: Does Environmental Equity Help Close the Achievement Gap?. Du Bois Review: Social Science Research on Race, 13(2), 379-395.

REAL School Gardens. (2013). What we do. Retrieved from http://www.realschoolgardens.org/what-we-do.aspx.

Reid, N. (1988). The Delphi technique: its contribution to the evaluation of professional practice. Professional competence and quality assurance in the caring professions, 230262.

Rohrbaugh, J. (1979). Improving the quality of group judgments: social judgment analysis and the Delphi technique, Organizational Behavior and Human Performance, 24, 73-92.

Rowe, P., Schuldheisz, J., \& VanderMars. H. (2003). Validation of SOFIT for measuring physical activity of first to eighth-grade students. Pediatric Exercise Science, 9(2), 136149.

Sackman, H. (1974). Delphi assessment: Expert opinion, forecasting, and group process (No. RAND-R-1283-PR). RAND CORP SANTA MONICA CA. 
Sallis, J., Strikmiller, P., \& Harsha, D. (1996). Validation of interviewer and self-administered physical activity checklist for fifth grade students. Medicine Science and Sports Exercise, 28(7), 840-851.

Sherer, P. M. (2006). The Benefits of Parks. San Francisco, CA: The Trust for Public Land.

Skelly, S. M., \& Bradley, J. C. (2007). The growing phenomenon of school gardens: Measuring their variation and their affect on students' sense of responsibility and attitudes toward science and the environment. Applied Environmental Education and Communication, 6(1), 97-104.

Skelly, S. M., \& Zajicek, J. M. (1998). The effect of an interdisciplinary garden program on the environmental attitudes of elementary school students. HortTechnology, 8(4), 579-583.

Smith, L. L., \& Motsenbocker, C. E. (2005). Impact of hands-on science through school gardening in Louisiana public elementary schools. HortTechnology, 15(3), 439-443.

Storrs, C. (2015, September 28). The blossoming health benefits of school gardens. Retrieved February 07, 2017, from http://www.cnn.com/2015/08/14/health/healthy-school-gardens/

Trelstad, B. 1997. "Little machines in their gardens: a history of school gardens in America, 1891-1920”. In: Landscape Journal, 16(2).

Troiano, R.P., Berrigan, D., Dodd, K.W., Mâsse, L.C., Tilert, T., \& McDowell, M. (2008). Physical activity in the United States measured by accelerometer. Medicine and Science in Sports and Exercise, 40(1), 181-188.

Turner, L., Sandoval, A., \& Chaloupka, F.J. (2014). School Garden Programs are on the Rise in U.S. Public Elementary Schools, but are Less Common in Schools with Economically Disadvantaged Student Populations. Chicago, IL: Bridging the Gap Program, Health Policy Center, Institute for Health Research and Policy, University of Illinois at Chicago. 
United States Department of Health and Human Services [USDHHS]. (2008). 2008 physical activity guidelines for Americans. Washington, D.C.: Author.

USDHHS. (2012). Physical activity guidelines for Americans mid-course report: Strategies to increase physical activity among youth. Washington, D.C.: Author.

U.S. White House Task Force on Childhood Obesity (2010). Solving the problem of childhood obesity within a generation. White House Task Force on Childhood Obesity Report to the President. Washington, D.C.: Executive Office of the President of the United States.

Waliczek, T. \& Zajicek, J.M. (1998). The Effect of a School Garden Program on Self-Esteem and Interpersonal Relationships of Children and Adolescents. Hort Technology (submitted).

Waliczek, T. M., Bradley, R. D., Lineberger, R. D., \& Zajicek, J. M. (2000). Using a web-based survey to research the benefits of children's gardening. HortTechnology, 10, 71-76.

Wells, N.M., Myers, B., \& Henderson, C.R. (2014). School gardens and physical activity: A randomized controlled trial of low-income elementary schools. Preventive Medicine, 69(1).

Wells, N.M., Myers, B.M., Todd, L.E., Barale, K., Gaolach, B., Ferenz, G., Aitken, M., Henderson, C.R., Tse, C., Pattison, K.O. and Taylor, C. (2015). The Effects of School Gardens on Children's Science Knowledge: A randomized controlled trial of low-income elementary schools. International Journal of Science Education, 37(17), 2858-2878.

Wilhelm, W.J. (2001). Alchemy of the Oracle: the Delphi technique. The Delta Pi Epsilon Journal, 43(1):6-26.

Williams, P.L., \& Webb, C. (1994). The Delphi technique: a methodological discussion. Journal of Advanced Nursing, 1994, 19:180-6. 
Wilson, M. L. (1945, June 15). Progress Reports of State Directors of Cooperative Extension Work on the Victory Garden and Home Food Production Programs. Washington, D.C: Government Printing Office. 


\section{Appendix B: Research Methodology Flowchart}

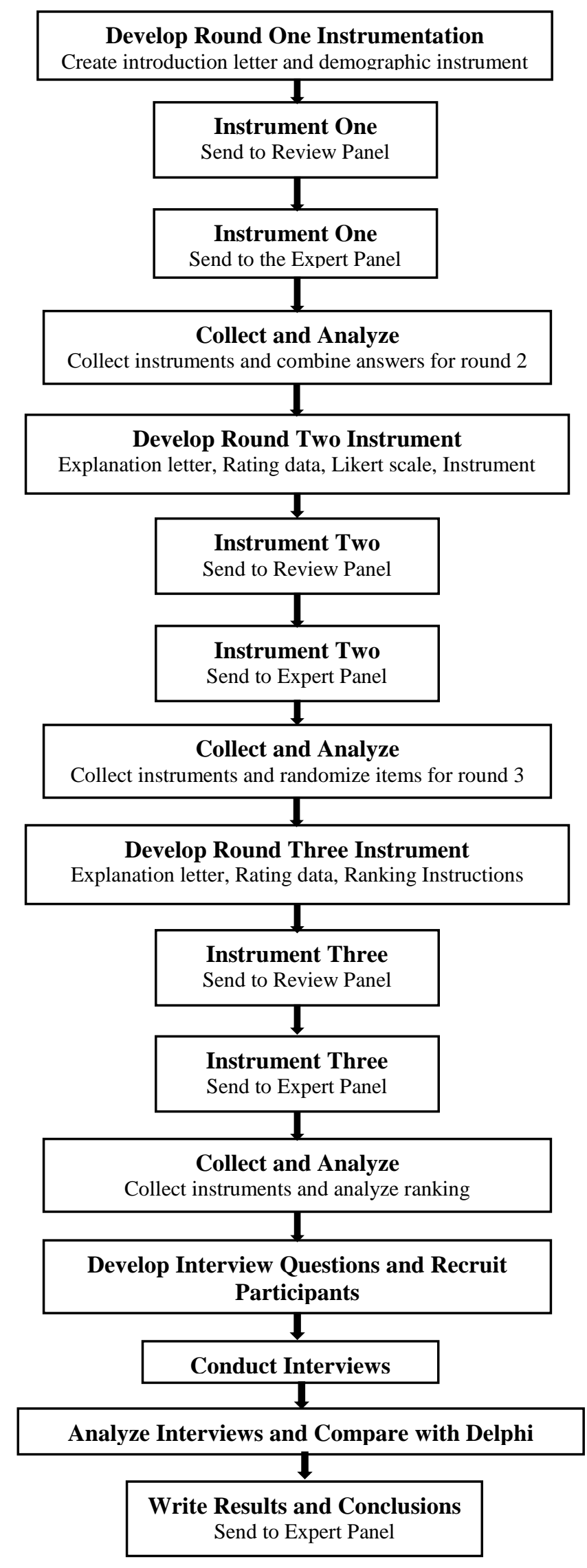




\title{
Appendix C: Invitation and Consent Email to Participants with Demographic Survey
}

\author{
Dear School Garden Expert,
}

This email is an invitation to participate in a research study regarding school garden programming in Washington, DC. You have been chosen to participate because of your expertise in school garden implementation. This study will require you to provide your expert opinion on the important elements of a successful school garden program in order to better inform others.

Please read the following information to help you better understand the study, and what you will be required to do.

\section{What is the purpose of the study?}

This study is designed to gain consensus on the best practices and recommendations among school gardening experts in Washington, DC. Though research has contributed positive results in developing the whole child through garden-based learning, there remains a strong need for practical "how-to" information that has proven to be effective in successful school garden programming. It is essential to gather expertise in assisting in the movement so that more projects are successful (Danks, 2010). We believe that you have the knowledge and expertise to help us provide that information to others.

\section{Why have you been invited to take part?}

As an established expert in this field we are looking forward to gaining your views about important components of a school garden program. Specifically, we would like to ask your views on the important components of successful schools gardens and key recommendations for school garden implementation in future school garden programs. We plan to choose 40 participants from a group of teachers, school administrators, organization directors and community partners, and garden coordinators.

\section{What will you be asked to do?}

This study is using a Delphi technique that seeks to obtain consensus on the opinions of experts through a series of short structured surveys.

Demographic Survey: As an expert panel member, after consenting to participate via email, you will be asked to answer demographic questions to help us better understand your position in providing school gardens in DC.

Round 1 Survey: Within a few days after completion, you will then be directed to Round 1 of the study where you will be asked to answer two open-ended questions regarding school garden programming. It is predicted that this should take approximately 20 minutes or less.

Round 2 and 3 Surveys: Once all experts' responses are received and analyzed, you will then be asked to complete Round Two of the questionnaire that will ask you to rate the list of predictors generated by the expert group. This process will continue in Round Three, or until a group consensus is achieved. In order to allow timely conclusion of the study we would respectfully request a response time of 1 week for completion of each of the three rounds. The surveys will be delivered to you using an online format, therefore, you will need access to the Internet and to an email account for communication purposes. 
Follow-up Interviews: Eight experts will be selected for interviews to further develop and describe the results from the Delphi study

\section{What do you need to know about the research?}

The Delphi study will be conducted by Hannah Kipfer, a doctoral student in the College of Physical Activity and Sport Sciences (CPASS) at West Virginia University (WVU) and supervised by Dr. Eloise Elliott, Ware Distinguished Professor, WVU.

\section{Confidentiality}

No personal information will be collected and survey responses will be collated anonymously using an identifying number known only to the participant and lead investigator. All responses received in the study will be strictly confidential, and your identity will not be divulged. Direct quotes to free-text answers may be used as part of the study report or later Delphi iterations, but these will be not be traceable back to you.

\section{Data protection}

Survey responses will be collected online using a quality-assured survey company, utilizing an encrypted internet server, Qualtrics. Results will be downloaded to an encrypted WVU computer to allow analysis by the research team. Data will be stored for the duration of the research project only and then deleted. You have the right to access submitted information and will be shown the results after each round and at the culmination of the study.

\section{Research ethics}

This study abides by the ethical requirements of WVU International Review Board, aimed to assure rigor, respect and responsibility in the conduct of the research project. A copy of the West Virginia University ethics committee application and decision letter is available on request.

\section{What do you do next to participate?}

We hope that you will be an expert panelist for this study as we feel that your knowledge and feedback will significantly contribute to current and future school garden programs throughout the U.S. If you agree to participate, please go to the link below to consent and to complete the demographic questions.

\section{https://wvu.qualtrics.com/jfe/form/SV_8cXrwOr5jezC4VT}

If you have any questions or concerns please do not hesitate to contact Hannah or Eloise Elliott by email at eloise.elliott@ mail.wvu.edu.

Thank you again for your time and contribution to the completion of this project.

Sincerely, Hannah J. Kipfer, M.S.

West Virginia University

Morgantown, WV

(814)795-2221

hjkipfer@mix.wvu.edu 


\section{Appendix D: Demographic Survey}

\section{Start of Block: Demographic Survey}

Thank you for choosing to participate in this study exploring school garden programming in Washington, DC. This demographic survey contains 5 questions and should only require 5 minutes to complete. You will be contacted via email within one week after completing this survey.

Page Break

Please enter your email address:

Please select your age range:

18-25 years old

26-35 years old

36-45 years old

- 46-55 years old

56-65 years old

O $66+$ years old

Please select the Ward(s) you currently support: (please select all that apply)
$\square \quad$ Ward 1
口 Ward 2
口 Ward 3
$\square \quad$ Ward 4
$\square \quad$ Ward 5
口 Ward 6
$\square \quad$ Ward 7
口 Ward 8
$\square \quad$ I do not support a specific Ward 
Please select the title that best fits your working relation to school garden programming: (please select all that apply)

$\square \quad$ Elementary school teacher (PreK-6th grade)

$\square$ Secondary school teacher (7th-12th grade)

$\square \quad$ Pre-service Teacher

$\square$ Elementary school administrator (PreK-6th grade)

$\square \quad$ Secondary school administrator (7th-12th grade)

$\square$ Organization director or staff

$\square$ Community partner

$\square \quad$ School garden coordinator

口 Parent

$\square \quad$ Volunteer

$\square \quad$ Local Extension Service provider

$\square \quad$ University Professor

$\square \quad$ Other (please describe)

Please select all the following that describe your role and or experiences with school garden programming:

$\square \quad$ Recruiting and supporting volunteers

- Facilitating professional development workshops

$\square \quad$ Have attended at least 2 school garden training workshops

$\square \quad$ Evaluates programs and/or generates reports

$\square$ Develops learning materials (curriculum, lesson plans, etc.)

$\square \quad$ Instructs garden lessons for school-aged children

$\square$ Coordinates student and/or parent engagement events

$\square \quad$ Provides support to classroom teachers

$\square \quad$ Participates in school garden committee meetings

$\square \quad$ Maintain the garden

$\square$ Provides support to at least one school in DC 


\title{
Appendix E: Instructions and Link to Round One Survey Email
}

\author{
Dear School Garden Expert,
}

Thank you for agreeing to participate in this study of school garden programming in Washington, D.C., which is my dissertation research at West Virginia University. Because of your expertise in school garden programming, you have been specifically selected to participate in the study. You are a part of a selected expert panel of approximately 40 school garden leaders that work with DC school garden programs.

\section{Confidentiality}

Your responses will not be identifiable and comments and ratings you provide will be strictly confidential and the information you provide will not be individually cited. Your thoughts and comments will provide an important foundation for further education, training, and research concerning school garden programming in the U.S.

\section{What your voluntary involvement entails.}

I am estimating that your participation will take you no more than two hours total over a period of about eight weeks. You will receive three study links via email, as well as a final summary of the results of the study for your own information.

\section{How the study will proceed.}

The end of this letter contains a link to the Round One survey.

\section{Round One will consist of:}

1.) Two open-ended questions and should take no more than 20 minutes to complete. The study is designed to enable you to save your answers and return to the questions later. This will allow you to set aside time as needed to think about your answers and attend to your work without having to address the questions all at one time.

2.) You will have 7 days to complete and return your Round One responses and comments.

3.) Approximately one week after all Round One comments are received and analyzed, you will receive a link to Round Two.

\section{Round Two will consist of:}

1.) Your comments from Round One.

2.) A summary of the responses of other experts presented in a manner that does not identify or link any comment to any individual participant.

3.) A brief set of questions developed from the comments of study participants that you will be asked to rate in importance using a 5-point scale.

4.) You will be asked to return your comments and ratings in 7 days. The estimated completion time for this round is 30 minutes.

5.) About one week after the group's Round Two ratings are received and analyzed, you will be emailed the set of Round Three questions, which will be similar to Round Two questions.

\section{Round Three will consist of:}

1.) A summary of Round Two results. 
2.) A final modified Likert-scaled set of questions. The estimated completion time for this round is 30 minutes.

\section{Follow-up Interviews:}

1) Eight study participants will be recruited for follow-up interviews.

2) Interviews will seek to further develop and describe the results from the Delphi study.

The starting date for the study is . Your responses and comments as part of this study will not contain any identifying information, and will be analyzed and summarized in combination with the responses of the group. This confidentiality is designed to ensure you feel comfortable sharing your perspectives as part of the panel. If you are willing to participate, the next step is to click on the following survey link.

\section{https://wvu.qualtrics.com/jfe/form/SV 880RdLp2An8XLkV}

Your commitment and willingness to lend your expertise to the goals of this study is significant. The insights and skills you share with the group have the potential to impact and further school garden education and programming.

Thank you again for participating. If you have questions, please feel welcome to email me at hjkipfer@mix.wvu.edu.

Warm regards,

Hannah J. Kipfer, M.S., WVU Doctoral Candidate

West Virginia University

hjkipfer@mix.wvu.edu

If you would like, you can also discuss this study with my dissertation supervisor:

Eloise Elliott, Ph.D.

West Virginia University

Eloise.Elliott@mix.wvu.edu 


\section{Appendix F: Round One Survey}

\section{Start of Block: Delphi Round One}

Thank you for choosing to participate in this study exploring school garden programming in Washington, DC. This Round One survey contains 2 questions and should take less than 20 minutes to complete. You may list up to three responses for each question.

Page Break

Please enter your Personal Identification Number

One key thing that leads to a sustainable school garden program is: (list up to three things)

Click to write Choice 1

O Click to write Choice 2

O Click to write Choice 3

Page Break

One recommendation for starting a successful school garden program is: (list up to three recommendations)

Click to write Choice 1

O Click to write Choice 2

Click to write Choice 3

Page Break 


\section{Appendix G: Round One 5-Stage Thematic Analysis}

\section{Thematic Analysis of ROUND 1 Q1 DATA}

\section{Emergent THEMES}

- 1 . Support (funding, personnel, staffing, volunteers, parents) - 24

- 2. Accessibility - 3

- 3. Interest/Buy-in - 16

- 4. Resources - 7

- 5. Infrastructure -8

- 6. Sustainability - 2

- 7. Planning - 14

- 8. Education - 10

- 9. Partnerships - 9

\section{Step 3: Indexing}

\begin{tabular}{|c|c|c|c|}
\hline 63 & CODE & $\begin{array}{l}\text { Responses to Question 1: One recommendation } \\
\text { for starting a successful school garden is: }\end{array}$ & Short Descriptor \\
\hline 1 & $\begin{array}{l}\text { Support } \\
\text { Partnerships }\end{array}$ & $\begin{array}{l}\text { Involve as many stakeholders as possible -- } \\
\text { administration, parents, teachers, students, cafeteria } \\
\text { staff, neighbors, etc. }\end{array}$ & Many stakeholders \\
\hline 2 & Accessibility & Accessible to students, staff, and parents & $\begin{array}{l}\text { to students, staff, } \\
\text { and parents }\end{array}$ \\
\hline 3 & Infrastructure & space for garden & Space \\
\hline 4 & $\begin{array}{l}\text { Planning } \\
\text { Infrastructure }\end{array}$ & $\begin{array}{l}\text { design your site to fit your needs (just because you } \\
\text { have the space doesn't mean you need to fill it up) }\end{array}$ & Space-design \\
\hline 5 & Support & community support & community \\
\hline 6 & $\begin{array}{l}\text { Planning } \\
\text { Interest/Buy-in } \\
\text { Partnerships }\end{array}$ & $\begin{array}{l}\text { Ask for input from the community from the onset of } \\
\text { the project instead of asking for feedback after you } \\
\text { have already started establishing part of the project. }\end{array}$ & $\begin{array}{l}\text { Community } \\
\text { partners }\end{array}$ \\
\hline 7 & Accessibility & Not accessible to those not affiliated with the school & community \\
\hline 8 & Support & administrative support & administration \\
\hline 9 & $\begin{array}{l}\text { Planning } \\
\text { Support }\end{array}$ & carefully consider staffing, garden use and funding & Staffing; funding \\
\hline 10 & Planning & strategic plan & Overall plan \\
\hline 11 & Accessibility & Accessible during school hours & During school hrs. \\
\hline 12 & Support & funds for tools and seeds & funding \\
\hline 13 & $\begin{array}{l}\text { Interest/Buy-in } \\
\text { Support } \\
\text { Partnerships }\end{array}$ & $\begin{array}{l}\text { have multiple stake holders in from as many parts of } \\
\text { school community as possible (teachers, admin, } \\
\text { parents/PTO) }\end{array}$ & $\begin{array}{l}\text { Many stakeholders; } \\
\text { partners }\end{array}$ \\
\hline 14 & Education & $\begin{array}{l}\text { educate our youth how most foods, especially } \\
\text { produce are grown }\end{array}$ & students \\
\hline 15 & Interest/Buy-in & Secure a site with actively engaged participants. & From participants \\
\hline
\end{tabular}




\begin{tabular}{|c|c|c|c|}
\hline 16 & $\begin{array}{l}\text { Sustainability } \\
\text { Planning }\end{array}$ & $\begin{array}{l}\text { Having a clear understanding/agreement between the } \\
\text { school and partners on the size, initial cost, } \\
\text { maintenance costs and possible plans for expansion of } \\
\text { the program to ensure that there is the preparation for } \\
\text { a multi-year investment and that schools/partners do } \\
\text { not feel overwhelmed by the maintenance. }\end{array}$ & $\begin{array}{l}\text { School/partner } \\
\text { agreements }\end{array}$ \\
\hline 17 & $\begin{array}{l}\text { Support } \\
\text { Resources }\end{array}$ & Startup funds/materials & $\begin{array}{l}\text { Funding and } \\
\text { resources }\end{array}$ \\
\hline 18 & Resources & $\begin{array}{l}\text { Contact school district to inquire about } \\
\text { services/resources available. }\end{array}$ & $\begin{array}{l}\text { Available resources } \\
\text { to help }\end{array}$ \\
\hline 19 & Support & Principle and staff support & Admin and staff \\
\hline 20 & $\begin{array}{l}\text { Support } \\
\text { Partnerships }\end{array}$ & $\begin{array}{l}\text { Embrace the parental community/organizations to } \\
\text { lend support. }\end{array}$ & Community/parents \\
\hline 21 & $\begin{array}{l}\text { Interest/Buy-in } \\
\text { Support } \\
\text { Sustainability } \\
\text { Partnerships } \\
\text { Education }\end{array}$ & $\begin{array}{l}\text { there is a group of invested participants who will not } \\
\text { quickly roll over, who are committed to the } \\
\text { administrative, educational and upkeep aspects of the } \\
\text { project }\end{array}$ & $\begin{array}{l}\text { Invested } \\
\text { stakeholders; } \\
\text { partners }\end{array}$ \\
\hline 22 & $\begin{array}{l}\text { Interest/Buy-in } \\
\text { Partnerships }\end{array}$ & An enthusiastic team & team \\
\hline 23 & $\begin{array}{l}\text { Interest/Buy-in } \\
\text { Planning }\end{array}$ & $\begin{array}{l}\text { Ask school faculty/admin to gather interest on school } \\
\text { gardens }\end{array}$ & From all involved \\
\hline 24 & Interest/Buy-in & Interested parents & parents \\
\hline 25 & $\begin{array}{l}\text { Support } \\
\text { Partnerships }\end{array}$ & Engage with community partners to lend support. & $\begin{array}{l}\text { Community } \\
\text { partners }\end{array}$ \\
\hline 26 & $\begin{array}{l}\text { Planning } \\
\text { Infrastructure } \\
\text { Resources }\end{array}$ & $\begin{array}{l}\text { that a garden actually makes sense on the available } \\
\text { land and that we are not trying to fit a garden in a } \\
\text { space that is not made for it (ie. picking what kind of } \\
\text { garden makes sense for the location and available } \\
\text { resources) }\end{array}$ & $\begin{array}{l}\text { Planning to fit } \\
\text { space and resources }\end{array}$ \\
\hline 27 & Support & Administrator support & administration \\
\hline 28 & Planning & Start small & Beginning planning \\
\hline 29 & Support & $\begin{array}{l}\text { Make sure that the school administration understands } \\
\text { the value of the program and wholeheartedly supports } \\
\text { it before you begin. }\end{array}$ & administration \\
\hline 30 & Planning & Plan on where you want the garden to be. Location & location \\
\hline 31 & Interest/Buy-in & Buy-in from school leadership and teachers & Admin/teachers \\
\hline 32 & Planning & Start small & Beginning planning \\
\hline 33 & Interest/Buy-in & $\begin{array}{l}\text { Make sure you have the school community's buy in - } \\
\text { involvement and participation from the school }\end{array}$ & $\begin{array}{l}\text { Community and } \\
\text { school }\end{array}$ \\
\hline 34 & $\begin{array}{l}\text { Infrastructure } \\
\text { Resources }\end{array}$ & $\begin{array}{l}\text { What do you need for your garden. Tools, Soil and } \\
\text { Materials }\end{array}$ & $\begin{array}{l}\text { Materials and } \\
\text { resources }\end{array}$ \\
\hline 35 & Support & $\begin{array}{l}\text { support from an organization with experience in } \\
\text { installing gardens }\end{array}$ & Community \\
\hline 36 & Support & Find your local network of experts & experts \\
\hline 37 & $\begin{array}{l}\text { Support } \\
\text { Interest/Buy-in }\end{array}$ & $\begin{array}{l}\text { Ensure you have parent support and create excitement } \\
\text { via workdays and garden celebrations }\end{array}$ & parents \\
\hline
\end{tabular}




\begin{tabular}{|c|c|c|c|}
\hline 38 & Support & $\begin{array}{l}\text { Who will be involved in keeping the garden. } \\
\text { Volunteers must be committed (students, staffs and } \\
\text { parents) }\end{array}$ & volunteers \\
\hline 39 & Planning & clear mission/ vision of program & Mission/vision \\
\hline 40 & Interest/Buy-in & Celebrate often & celebrate \\
\hline 41 & $\begin{array}{l}\text { Support } \\
\text { Infrastructure } \\
\end{array}$ & A dedicated, knowledgeable, skilled coordinator & coordinator \\
\hline 42 & Support & staff to support it & staff \\
\hline 43 & $\begin{array}{l}\text { Education } \\
\text { Infrastructure }\end{array}$ & $\begin{array}{l}\text { Hire a full-time horticulture teacher/registered } \\
\text { horticultural therapist with graduate level education in } \\
\text { horticulture, agricultural extension education, human } \\
\text { services and at least two years' experience using those } \\
\text { elements together in educational programming and } \\
\text { delivery. }\end{array}$ & Specialized teacher \\
\hline 44 & $\begin{array}{l}\text { Support } \\
\text { Interest/Buy-in }\end{array}$ & $\begin{array}{l}\text { Ensure top-down buy-in from the principal or district } \\
\text { or work to build this support. }\end{array}$ & Principal/district \\
\hline 45 & Education & $\begin{array}{l}\text { To educate the students the importance of plants in } \\
\text { our lives. }\end{array}$ & students \\
\hline 46 & Interest/Buy-in & $\begin{array}{l}\text { Buy in from the school community (parents, } \\
\text { leadership, teachers, students) }\end{array}$ & All involved \\
\hline 47 & Resources & materials & materials \\
\hline 48 & Support & $\begin{array}{l}\text { An accessible annual budget for the program that is } \\
\text { no less than } \$ 10,000.00 \text { for equipment and materials. } \\
\text { This implies the unfailing support of the school } \\
\text { administrator - from the very top on down to the } \\
\text { teachers and paraprofessionals. }\end{array}$ & $\begin{array}{l}\text { Funding, } \\
\text { administration }\end{array}$ \\
\hline 49 & Education & $\begin{array}{l}\text { Provide research to teachers/parents about the } \\
\text { benefits of school gardens. }\end{array}$ & $\begin{array}{l}\text { Educating } \\
\text { teachers/parents }\end{array}$ \\
\hline 50 & Education & $\begin{array}{l}\text { To give them an outdoor experience with hands on } \\
\text { activities with nature }\end{array}$ & students \\
\hline 51 & Resources & access to sufficient resources & $\begin{array}{l}\text { Sufficient } \\
\text { resources }\end{array}$ \\
\hline 52 & $\begin{array}{l}\text { Planning } \\
\text { Infrastructure } \\
\end{array}$ & plan and location & Plan and location \\
\hline 53 & $\begin{array}{l}\text { Support } \\
\text { Infrastructure }\end{array}$ & $\begin{array}{l}\text { A budget in facilities operations to support the } \\
\text { installation of accessible raised beds, irrigation } \\
\text { systems (just under the surface hard pipe drip) that are } \\
\text { on an accessible timer, high porosity soilless growing } \\
\text { medium, and the proper growing environment } \\
\text { (whether outdoors, indoors, using conventional in } \\
\text { ground planting or aquaponics. }\end{array}$ & $\begin{array}{l}\text { Funding to support } \\
\text { needed } \\
\text { infrastructure }\end{array}$ \\
\hline 54 & Education & $\begin{array}{l}\text { To engage them with the important knowledge to } \\
\text { explore more by tasting the produce they have grown } \\
\text { locally instead of buying from a market }\end{array}$ & Students/parents \\
\hline 55 & Support & Administrative Support & administrative \\
\hline 56 & $\begin{array}{l}\text { Support } \\
\text { Interest/Buy-in }\end{array}$ & $\begin{array}{l}\text { Enfranchise parents and faculty and get them to help } \\
\text { with the actual gardening alongside students }\end{array}$ & Parents and faculty \\
\hline
\end{tabular}




\begin{tabular}{|l|l|l|l|}
\hline 57 & Planning & start small & Allies within the teachers - passionate gardeners \\
\hline 58 & Partnerships & $\begin{array}{l}\text { Teachers and } \\
\text { gardeners }\end{array}$ \\
\hline 59 & $\begin{array}{l}\text { Education } \\
\text { Interest/Buy-in }\end{array}$ & $\begin{array}{l}\text { Generate enthusiasm by connecting the garden with } \\
\text { relevant coursework in as many grades as possible }\end{array}$ & $\begin{array}{l}\text { Teachers and } \\
\text { students }\end{array}$ \\
\hline 60 & Partnerships & $\begin{array}{l}\text { make sure there is a team - don't let one enthusiastic } \\
\text { person be labeled "the school garden person" }\end{array}$ & team \\
\hline 61 & $\begin{array}{l}\text { Education } \\
\text { Resources }\end{array}$ & $\begin{array}{l}\text { Knowledge of where to find resources (especially } \\
\text { free) }\end{array}$ & Finding resources \\
\hline 62 & $\begin{array}{l}\text { Education } \\
\text { Interest/Buy-in }\end{array}$ & $\begin{array}{l}\text { Grow something students can harvest and eat as early } \\
\text { as possible in the program to generate excitement for } \\
\text { the project }\end{array}$ & Students/parents \\
\hline 63 & Planning & be clear about goals and link them to school goals & $\begin{array}{l}\text { Program align with } \\
\text { school goals }\end{array}$ \\
\hline
\end{tabular}

\section{Step 4: Charting}

\section{(Example: Support)}

\begin{tabular}{|l|l|l|l|}
\hline 24 & \multicolumn{3}{|c|}{ THEME 1: SUPPORT } \\
\hline 1 & $\begin{array}{l}\text { Support } \\
\text { Partnerships }\end{array}$ & $\begin{array}{l}\text { Involve as many stakeholders as possible -- } \\
\text { administration, parents, teachers, students, cafeteria } \\
\text { staff, neighbors, etc. }\end{array}$ & Many stakeholders \\
\hline 2 & Support & community support & community \\
\hline 3 & Support & administrative support & administration \\
\hline 4 & $\begin{array}{l}\text { Planning } \\
\text { Support }\end{array}$ & carefully consider staffing, garden use and funding & Staffing; funding \\
\hline 5 & Support & funds for tools and seeds & funding \\
\hline 6 & $\begin{array}{l}\text { Interest/Buy-in } \\
\text { Pupport }\end{array}$ & $\begin{array}{l}\text { have multiple stake holders in from as many parts of } \\
\text { school community as possible (teachers, admin, } \\
\text { parents/pto) }\end{array}$ & $\begin{array}{l}\text { Many stakeholders; } \\
\text { partners }\end{array}$ \\
\hline 7 & $\begin{array}{l}\text { Support } \\
\text { Resources }\end{array}$ & Startup funds/materials & $\begin{array}{l}\text { Funding and } \\
\text { resources }\end{array}$ \\
\hline 8 & Support & Principle and staff support & Admin and staff \\
\hline 9 & $\begin{array}{l}\text { Support } \\
\text { Partnerships }\end{array}$ & $\begin{array}{l}\text { Embrace the parental community/organizations to } \\
\text { lend support. }\end{array}$ & Community/parents \\
\hline 10 & $\begin{array}{l}\text { Interest/Buy-in } \\
\text { Support } \\
\text { Sustainability } \\
\text { Partnerships }\end{array}$ & $\begin{array}{l}\text { there is a group of invested participants who will not } \\
\text { quickly roll over, who are committed to the } \\
\text { administrative, educational and upkeep aspects of the } \\
\text { project }\end{array}$ & $\begin{array}{l}\text { Invested } \\
\text { stakeholders; } \\
\text { partners }\end{array}$ \\
\hline 11 & $\begin{array}{l}\text { Support } \\
\text { Partnerships }\end{array}$ & Engage with community partners to lend support. & $\begin{array}{l}\text { Community } \\
\text { partners }\end{array}$ \\
\hline 12 & Support & Administrator support & administration \\
\hline
\end{tabular}




\begin{tabular}{|c|c|c|c|}
\hline 13 & Support & $\begin{array}{l}\text { Make sure that the school administration understands } \\
\text { the value of the program and wholeheartedly supports } \\
\text { it before you begin. }\end{array}$ & administration \\
\hline 14 & Support & $\begin{array}{l}\text { support from an organization with experience in } \\
\text { installing gardens }\end{array}$ & Community \\
\hline 15 & Support & Find your local network of experts & experts \\
\hline 16 & $\begin{array}{l}\text { Support } \\
\text { Interest/Buy-in }\end{array}$ & $\begin{array}{l}\text { Ensure you have parent support and create excitement } \\
\text { via workdays and garden celebrations }\end{array}$ & parents \\
\hline 17 & Support & $\begin{array}{l}\text { Who will be involved in keeping the garden. } \\
\text { Volunteers must be committed (students, staffs and } \\
\text { parents) }\end{array}$ & volunteers \\
\hline 18 & $\begin{array}{l}\text { Support } \\
\text { Infrastructure }\end{array}$ & A dedicated, knowledgeable, skilled coordinator & coordinator \\
\hline 19 & Support & staff to support it & staff \\
\hline 20 & $\begin{array}{l}\text { Support } \\
\text { Interest/Buy-in }\end{array}$ & $\begin{array}{l}\text { Ensure top-down buy-in from the principal or district } \\
\text { or work to build this support. }\end{array}$ & Principal/district \\
\hline 21 & Support & $\begin{array}{l}\text { An accessible annual budget for the program that is } \\
\text { no less than } \$ 10,000.00 \text { for equipment and materials. } \\
\text { This implies the unfailing support of the school } \\
\text { administrator - from the very top on down to the } \\
\text { teachers and paraprofessionals. }\end{array}$ & $\begin{array}{l}\text { Funding, } \\
\text { administration }\end{array}$ \\
\hline 22 & $\begin{array}{l}\text { Support } \\
\text { Infrastructure }\end{array}$ & $\begin{array}{l}\text { A budget in facilities operations to support the } \\
\text { installation of accessible raised beds, irrigation } \\
\text { systems (just under the surface hard pipe drip) that are } \\
\text { on an accessible timer, high porosity soilless growing } \\
\text { medium, and the proper growing environment } \\
\text { (whether outdoors, indoors, using conventional in } \\
\text { ground planting or aquaponics. }\end{array}$ & $\begin{array}{l}\text { Funding to support } \\
\text { needed } \\
\text { infrastructure }\end{array}$ \\
\hline 23 & Support & Administrative Support & administrative \\
\hline 24 & $\begin{array}{l}\text { Support } \\
\text { Interest/Buy-in }\end{array}$ & $\begin{array}{l}\text { Enfranchise parents and faculty and get them to help } \\
\text { with the actual gardening alongside students }\end{array}$ & Parents and faculty \\
\hline
\end{tabular}

\section{SUPPORT THEME BROKEN DOWN BY CATEGORIES}

\begin{tabular}{|l|l|l|l|}
\hline & \multicolumn{3}{|c|}{ CATEGORY 1: SUPPORT from Administration } \\
\hline 1 & $\begin{array}{l}\text { Support } \\
\text { Partnerships }\end{array}$ & $\begin{array}{l}\text { Involve as many stakeholders as possible -- } \\
\text { administration, parents, teachers, students, cafeteria } \\
\text { staff, neighbors, etc. }\end{array}$ & $\begin{array}{l}\text { Many } \\
\text { stakeholders }\end{array}$ \\
\hline 3 & Support & administrative support & administration \\
\hline 6 & $\begin{array}{l}\text { Interest/Buy-in } \\
\text { Support } \\
\text { Partnerships }\end{array}$ & $\begin{array}{l}\text { have multiple stake holders in from as many parts of } \\
\text { school community as possible (teachers, admin, } \\
\text { parents/pto) }\end{array}$ & $\begin{array}{l}\text { Many } \\
\text { stakeholders; } \\
\text { partners }\end{array}$ \\
\hline 8 & Support & Principle and staff support & Admin and staff \\
\hline
\end{tabular}




\begin{tabular}{|c|c|c|c|}
\hline 10 & $\begin{array}{l}\text { Interest/Buy-in } \\
\text { Support } \\
\text { Sustainability } \\
\text { Partnerships }\end{array}$ & $\begin{array}{l}\text { there is a group of invested participants who will not } \\
\text { quickly roll over, who are committed to the } \\
\text { administrative, educational and upkeep aspects of the } \\
\text { project }\end{array}$ & $\begin{array}{l}\text { Invested } \\
\text { stakeholders; } \\
\text { partners }\end{array}$ \\
\hline 12 & Support & Administrator support & administration \\
\hline 13 & Support & $\begin{array}{l}\text { Make sure that the school administration understands } \\
\text { the value of the program and wholeheartedly supports it } \\
\text { before you begin. }\end{array}$ & administration \\
\hline 20 & $\begin{array}{l}\text { Support } \\
\text { Interest/Buy-in }\end{array}$ & $\begin{array}{l}\text { Ensure top-down buy-in from the principal or district or } \\
\text { work to build this support. }\end{array}$ & Principal/district \\
\hline 21 & Support & $\begin{array}{l}\text { An accessible annual budget for the program that is no } \\
\text { less than } \$ 10,000.00 \text { for equipment and materials. This } \\
\text { implies the unfailing support of the school administrator } \\
\text { - from the very top on down to the teachers and } \\
\text { paraprofessionals. }\end{array}$ & $\begin{array}{l}\text { Funding, } \\
\text { administration }\end{array}$ \\
\hline 23 & Support & Administrative Support & administrative \\
\hline
\end{tabular}

\begin{tabular}{|l|l|l|l|}
\hline & \multicolumn{3}{|c|}{ CATEGORY 2: SUPPORT from Community/Partners } \\
\hline 2 & Support & community support & community \\
\hline 9 & $\begin{array}{l}\text { Support } \\
\text { Partnerships }\end{array}$ & $\begin{array}{l}\text { Embrace the parental community/organizations to lend } \\
\text { support. }\end{array}$ & Community/parents \\
\hline 10 & $\begin{array}{l}\text { Interest/Buy-in } \\
\text { Support } \\
\text { Sustainability } \\
\text { Partnerships }\end{array}$ & $\begin{array}{l}\text { there is a group of invested participants who will not } \\
\text { quickly roll over, who are committed to the } \\
\text { administrative, educational and upkeep aspects of the } \\
\text { project }\end{array}$ & $\begin{array}{l}\text { Invested } \\
\text { stakeholders; } \\
\text { partners }\end{array}$ \\
\hline 11 & $\begin{array}{l}\text { Support } \\
\text { Partnerships }\end{array}$ & $\begin{array}{l}\text { Engage with community partners to lend support. } \\
\text { support from an organization with experience in } \\
\text { installing gardens }\end{array}$ & $\begin{array}{l}\text { Community } \\
\text { partners }\end{array}$ \\
\hline 14 & Support & \multicolumn{2}{l}{ Community } \\
\hline
\end{tabular}

\begin{tabular}{|l|l|l|l|}
\hline \multicolumn{4}{|c|}{ CATEGORY 3: SUPPORT from Teachers/Staff/Experts } \\
\hline 4 & $\begin{array}{l}\text { Planning } \\
\text { Support }\end{array}$ & carefully consider staffing, garden use and funding & Staffing; funding \\
\hline 6 & $\begin{array}{l}\text { Interest/Buy-in } \\
\text { Support } \\
\text { Partnerships }\end{array}$ & $\begin{array}{l}\text { have multiple stake holders in from as many parts of } \\
\text { school community as possible (teachers, admin, } \\
\text { parents/PTA) }\end{array}$ & $\begin{array}{l}\text { Many } \\
\text { stakeholders; } \\
\text { partners }\end{array}$ \\
\hline 8 & Support & Principle and staff support & Admin and staff \\
\hline 15 & Support & Find your local network of experts & experts \\
\hline 17 & Support & $\begin{array}{l}\text { Who will be involved in keeping the garden. Volunteers } \\
\text { must be committed (students, staffs and parents) }\end{array}$ & volunteers \\
\hline 18 & $\begin{array}{l}\text { Support } \\
\text { Infrastructure }\end{array}$ & A dedicated, knowledgeable, skilled coordinator & coordinator \\
\hline 19 & Support & staff to support it & staff \\
\hline 24 & $\begin{array}{l}\text { Support } \\
\text { Interest/Buy-in }\end{array}$ & $\begin{array}{l}\text { Enfranchise parents and faculty and get them to help } \\
\text { with the actual gardening alongside students }\end{array}$ & $\begin{array}{l}\text { Parents and } \\
\text { faculty }\end{array}$ \\
\hline
\end{tabular}




\begin{tabular}{|l|l|l|l|}
\hline & \multicolumn{3}{|c|}{ CATEGORY 4: SUPPORT from Parents } \\
\hline 9 & $\begin{array}{l}\text { Support } \\
\text { Partnerships }\end{array}$ & $\begin{array}{l}\text { embrace the parental community/organizations to lend } \\
\text { support. }\end{array}$ & Community/parents \\
\hline 16 & $\begin{array}{l}\text { Support } \\
\text { Interest/Buy-in }\end{array}$ & $\begin{array}{l}\text { Ensure you have parent support and create excitement } \\
\text { via workdays and garden celebrations }\end{array}$ & parents \\
\hline 24 & $\begin{array}{l}\text { Support } \\
\text { Interest/Buy-in }\end{array}$ & $\begin{array}{l}\text { Enfranchise parents and faculty and get them to help } \\
\text { with the actual gardening alongside students }\end{array}$ & Parents and faculty \\
\hline
\end{tabular}

\begin{tabular}{|l|l|l|l|}
\hline & \multicolumn{3}{|c|}{ CATEGORY 5: SUPPORT from Many Stakeholders } \\
\hline 1 & $\begin{array}{l}\text { Support } \\
\text { Partnerships }\end{array}$ & $\begin{array}{l}\text { Involve as many stakeholders as possible -- } \\
\text { administration, parents, teachers, students, cafeteria staff, } \\
\text { neighbors, etc. }\end{array}$ & $\begin{array}{l}\text { Many } \\
\text { stakeholders }\end{array}$ \\
\hline 6 & $\begin{array}{l}\text { Interest/Buy-in } \\
\text { Support } \\
\text { Partnerships }\end{array}$ & $\begin{array}{l}\text { have multiple stake holders in from as many parts of } \\
\text { school community as possible (teachers, admin, } \\
\text { parents/pto) }\end{array}$ & $\begin{array}{l}\text { Many } \\
\text { stakeholders; } \\
\text { partners }\end{array}$ \\
\hline 10 & $\begin{array}{l}\text { Interest/Buy-in } \\
\text { Support } \\
\text { Sustainability } \\
\text { Partnerships }\end{array}$ & $\begin{array}{l}\text { there is a group of invested participants who will not } \\
\text { quickly roll over, who are committed to the } \\
\text { administrative, educational and upkeep aspects of the } \\
\text { project }\end{array}$ & $\begin{array}{l}\text { Invested } \\
\text { stakeholders; } \\
\text { partners }\end{array}$ \\
\hline
\end{tabular}

\begin{tabular}{|l|l|l|l|}
\hline & \multicolumn{3}{|c|}{ CATEGORY 6: SUPPORT -Funding } \\
\hline 4 & $\begin{array}{l}\text { Planning } \\
\text { Support }\end{array}$ & carefully consider staffing, garden use and funding & Staffing; funding \\
\hline 5 & Support & funds for tools and seeds & funding \\
\hline 7 & $\begin{array}{l}\text { Support } \\
\text { Resources }\end{array}$ & Startup funds/materials & $\begin{array}{l}\text { Funding and } \\
\text { resources }\end{array}$ \\
\hline 21 & Support & $\begin{array}{l}\text { An accessible annual budget for the program that is no } \\
\text { less than } \$ 10,000.00 \text { for equipment and materials. This } \\
\text { implies the unfailing support of the school administrator } \\
\text { - from the very top on down to the teachers and } \\
\text { paraprofessionals. }\end{array}$ & $\begin{array}{l}\text { Funding, } \\
\text { administration }\end{array}$ \\
\hline
\end{tabular}




\section{Appendix H: Round Two Survey}

Thank you for taking the time to participate in this study. You will now be presented with the list of developed statements from Round One. A total of 145 responses were submitted and have been synthesized into 60 statements. In this round of data collection (Round Two), you will be asked to rate each question on a level of importance scale. If a question receives a mean group rating higher than "moderately important" it will be considered as meeting consensus and will move on to the final round of data collection (Round Three). Please use the arrows at the bottom of each page to navigate through the survey.

Please enter the e-mail address in-which you are receiving communication regarding this study:

The statements below were gathered from this Round One question: "One key thing that leads to a successful school garden program is". Please rate each statement at the importance level you feel is best suited.

\begin{tabular}{|c|c|c|c|c|c|}
\hline & $\begin{array}{l}\text { Not at all } \\
\text { important }\end{array}$ & $\begin{array}{l}\text { Slightly } \\
\text { important }\end{array}$ & $\begin{array}{l}\text { Moderately } \\
\text { important }\end{array}$ & $\begin{array}{c}\text { Very } \\
\text { important }\end{array}$ & $\begin{array}{l}\text { Extremely } \\
\text { important }\end{array}$ \\
\hline $\begin{array}{l}\text { Ensuring top-down buy-in from the school } \\
\text { district and administration to build } \\
\text { support. }\end{array}$ & 0 & 0 & 0 & 0 & 0 \\
\hline $\begin{array}{l}\text { Engaging a group of invested community } \\
\text { partners who are committed to the } \\
\text { administrative, educational and upkeep } \\
\text { aspects of the project long-term. }\end{array}$ & $\bigcirc$ & 0 & 0 & $\bigcirc$ & 0 \\
\hline $\begin{array}{l}\text { Hiring a full-time horticulture teacher or } \\
\text { registered horticulture therapist. }\end{array}$ & 0 & 0 & 0 & 0 & 0 \\
\hline $\begin{array}{c}\text { Establishing a team and a network of } \\
\text { partners with clearly laid out } \\
\text { responsibilities. }\end{array}$ & 0 & 0 & 0 & 0 & 0 \\
\hline $\begin{array}{l}\text { Hiring a dedicated, knowledgeable skilled } \\
\text { coordinator. }\end{array}$ & 0 & 0 & 0 & 0 & 0 \\
\hline $\begin{array}{l}\text { Having a position designated for overall } \\
\text { school garden management. }\end{array}$ & 0 & 0 & 0 & $\bigcirc$ & $\bigcirc$ \\
\hline $\begin{array}{l}\text { Buy-in from multiple stakeholders in the } \\
\text { school community (teachers, students, } \\
\text { school staff, and PTA). }\end{array}$ & 0 & 0 & 0 & $\bigcirc$ & 0 \\
\hline $\begin{array}{l}\text { Embracing the parental community to lend } \\
\text { support and encouraging them to help with } \\
\text { gardening alongside students. }\end{array}$ & 0 & 0 & 0 & 0 & 0 \\
\hline $\begin{array}{l}\text { Gaining support from community partners } \\
\text { that assist with development and } \\
\text { installation of the garden in the available } \\
\text { school space. }\end{array}$ & 0 & 0 & 0 & $\bigcirc$ & $\bigcirc$ \\
\hline $\begin{array}{c}\text { Securing start-up funding for garden } \\
\text { development, equipment, and materials. }\end{array}$ & 0 & 0 & 0 & $\mathrm{O}$ & 0 \\
\hline
\end{tabular}


Ensuring garden access to students, staff, and parents during school hours.

Ensure garden access to community members after school hours.

Securing a site with actively engaged participants and an enthusiastic team.

Ensuring parent interest and support via workdays and garden celebrations.

Generating student enthusiasm by connecting the garden with students' coursework.

Celebrating garden program achievements often.

Contacting school district to inquire about services/resources available.

Knowing where to find free resources and educational materials.

Having a plan for the available space, resources, and materials that are available.

Starting with a manageable size.

Creating a budget in facilities operations to support maintenance of the different growing structures.

Having an agreement with the school and all stakeholders on the size, initial cost, maintenance cost, and future plans of the garden.

Ensuring stakeholders understand are prepared to fund a multi-year investment.

Gathering input from the community at the onset of the project rather than ask for feedback once plans are developed.

Creating clear goals and linking them to the schools goals.

Developing a vision with pictures for the coming 10 years and share it with stakeholders

Developing a multi-year strategic plan that includes development, maintenance, staffing, instructional goals, and budget. 
Educating the students on food and nutrition and the importance of growing and eating local produce.

Providing the students with an outdoor experience with hands-on activities in nature.

Connecting the garden with program activities with content standards across the curriculum.

Growing something students can harvest and eat as early as possible in the program.

$\begin{array}{ccccc}0 & 0 & 0 & 0 & 0 \\ 0 & 0 & 0 & 0 & 0 \\ 0 & 0 & 0 & 0 & 0 \\ 0 & 0 & 0 & 0 & 0 \\ 0 & 0 & 0 & 0 & 0\end{array}$

Providing research to teachers/parents about the benefits of school gardens. 
The statements below were gathered from this Round One question: "One thing that leads to a sustainable school garden program is". Please rate each statement at the importance level you feel is best suited.

\begin{tabular}{|c|c|c|c|c|c|}
\hline & $\begin{array}{l}\text { Not at all } \\
\text { important }\end{array}$ & $\begin{array}{l}\text { Slightly } \\
\text { important }\end{array}$ & $\begin{array}{l}\text { Moderately } \\
\text { important }\end{array}$ & $\begin{array}{l}\text { Very } \\
\text { important }\end{array}$ & $\begin{array}{l}\text { Extremely } \\
\text { important }\end{array}$ \\
\hline $\begin{array}{l}\text { Hiring a full-time, knowledgeable } \\
\text { coordinator to manage and maintain the } \\
\text { school garden program. }\end{array}$ & $\mathrm{O}$ & O & $\mathrm{O}$ & $\mathrm{O}$ & $\mathrm{O}$ \\
\hline $\begin{array}{l}\text { Responsibilities delegated throughout the } \\
\text { school community. }\end{array}$ & $\mathrm{O}$ & $\mathrm{O}$ & O & $\mathrm{O}$ & O \\
\hline $\begin{array}{l}\text { Involving cafeteria staff support to help } \\
\text { incorporate new foods. }\end{array}$ & O & $\mathrm{O}$ & 0 & 0 & O \\
\hline $\begin{array}{l}\text { Involving community members and } \\
\text { neighbors to help take care of the garden. }\end{array}$ & $\mathrm{O}$ & $\mathrm{O}$ & O & $\mathrm{O}$ & $\mathrm{O}$ \\
\hline $\begin{array}{l}\text { Involving parents and families to help take } \\
\text { care of the garden. }\end{array}$ & 0 & $\mathrm{O}$ & O & $\mathrm{O}$ & $\mathrm{O}$ \\
\hline $\begin{array}{l}\text { Buy-in and commitment from the school } \\
\text { administration. }\end{array}$ & $\mathrm{O}$ & $\mathrm{O}$ & 0 & 0 & O \\
\hline $\begin{array}{l}\text { Buy-in and commitment from the teachers } \\
\text { and staff. }\end{array}$ & $\mathrm{O}$ & $\mathrm{O}$ & 0 & 0 & O \\
\hline $\begin{array}{c}\text { Creating a sense of ownership with the } \\
\text { students. }\end{array}$ & 0 & $\mathrm{O}$ & $\mathrm{O}$ & 0 & O \\
\hline $\begin{array}{l}\text { Buy-in and commitment from parents and } \\
\text { families. }\end{array}$ & 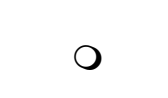 & $\mathrm{O}$ & 0 & $\mathrm{O}$ & O \\
\hline $\begin{array}{l}\text { Buy-in and commitment from the } \\
\text { community partners and volunteers. }\end{array}$ & $\mathrm{O}$ & $\mathrm{O}$ & 0 & 0 & O \\
\hline $\begin{array}{l}\text { Collaboration between the networks of } \\
\text { stakeholders. }\end{array}$ & $\mathrm{O}$ & $\mathrm{O}$ & 0 & 0 & O \\
\hline Having an enthusiastic team. & $\mathrm{O}$ & $\mathrm{O}$ & O & O & O \\
\hline $\begin{array}{l}\text { Creating a realistic, multi-year budget for } \\
\text { the whole program. }\end{array}$ & 0 & 0 & 0 & 0 & O \\
\hline $\begin{array}{l}\text { An accessible and realistic multi-year budget } \\
\text { for the program that is supported by the } \\
\text { school community. }\end{array}$ & $\mathrm{O}$ & $\mathrm{O}$ & $\mathrm{O}$ & $\mathrm{O}$ & O \\
\hline $\begin{array}{l}\text { An accessible and realistic multi-year budget } \\
\text { for the program that is supported by the } \\
\text { local community partners. }\end{array}$ & $\mathrm{O}$ & $\mathrm{O}$ & O & O & $\mathrm{O}$ \\
\hline $\begin{array}{l}\text { Volunteers to use and maintain the garden } \\
\text { during the summer. }\end{array}$ & $\mathrm{O}$ & $\mathrm{O}$ & O & O & O \\
\hline
\end{tabular}


Opening the garden to community members for events, work-days, markets, etc.

Creating a schedule for garden access, including non-growing months.

Involving all grades and teachers in the garden.

To connect the priorities of the garden program to those of the school and school culture.

To collaborate with after-school programs to promote garden clubs to help with garden maintenance.

Having a yearlong instructional plan that is relevant and a part of the overall school curriculum.

Having a clear, easy to follow, standardsbased curriculum.

Providing training for teachers on how to incorporate the garden as an outdoor classroom.

Ensuring that supplies and materials are well-organized and are based on the agegroup of the students.

Having continual access to materials (seeds, plants, soil) to maintain the garden.

To design space and plantings so that growth occurs in phases throughout the school year to help decipher realistic yearly maintenance.

To add at least one new and exciting element each year, such as growing new items, raising bees, etc.

End of Block: Consensus Building Round 2 Survey 


\section{Appendix I: Round Three Survey}

Thank you for your time and commitment to completion of this study. You will now be presented with a list of final statements and group scores from Round Two. You may choose to keep your same rating (see attached document) or re-rate the item with a higher or lower score. In order for an item to meet final consensus, it will need to be rated as a 4 (very important) or higher by $75 \%$ of the panel. Any item that fails to meet these criteria will be considered noncritical and will be excluded from the results. Please use the arrows at the bottom of each page to navigate through the survey.

Please enter the e-mail address in-which you are receiving communication regarding this study:

Question One: Please re-rate the following 18 items regarding successful school garden programming.

\begin{tabular}{l|cccc}
\hline Re-rate or keep score for items from Question One & \\
\hline & $\begin{array}{c}1=\text { Not at } \\
\text { all }\end{array}$ & $\begin{array}{c}2= \\
\text { Slightly }\end{array}$ & $\begin{array}{c}\text { Moderately } \\
\text { important }\end{array} \begin{array}{c}4=\text { Very } \\
\text { important }\end{array} \quad \begin{array}{c}\text { Extremely } \\
\text { important }\end{array}$ \\
\hline
\end{tabular}


Engaging a group of invested community partners who are committed to the administrative, educational and upkeep aspects of the project long-term. (Average

$$
\text { Group Score }=3.8 \text { ) }
$$

Hiring a full-time horticulture teacher or registered horticulture therapist. (Average Group Score $=2.9$ )

Establishing a team and a network of partners with clearly laid out responsibilities. (Average Group Score = 3.9)

Embracing the parental community to lend support and encouraging them to help with gardening alongside students. (Average Group Score $=3.6$ )

Gaining support from community partners that assist with development and installation of the garden in the available school space. (Average Group Score $=3.5$ )

Ensure garden access to community members after school hours. (Average Group Score $=2.7$ )

Securing a site with actively engaged participants and an enthusiastic team. (Average Group Score $=3.9$ )

Ensuring parent interest and support via workdays and garden celebrations. (Average Group Score $=3.4$ )

Contacting school district to inquire about services/resources available. (Average Group Score = 3.6)

Creating a budget in facilities operations to support maintenance of the different growing structures.

(Average Group Score $=3.6$ )

Having an agreement with the school and all stakeholders on the size, initial cost, maintenance cost, and future plans for the garden. (Average Group Score $=3.8)$

Ensuring stakeholders understand are prepared to fund a multi-year investment. (Average Group Score $=3.9$ )

Gathering input from the community at the onset of the project rather than ask for feedback once plans are developed. (Average Group Score $=3.5$ )

Creating clear goals and linking them to the schools goals. (Average Group Score $=4$ )

Developing a vision with pictures for the coming 10 years and share it with stakeholders. (Average Group Score $=3.1$ ) 
Developing a multi-year strategic plan that includes development, maintenance, staffing, instructional goals, and budget. (Average Group Score = 3.5)

Growing something students can harvest and eat as early as possible in the program. (Average Group Score

$$
=3.9 \text { ) }
$$

Providing research to teachers/parents about the benefits of school gardens. (Average Group Score $=3.8$ )

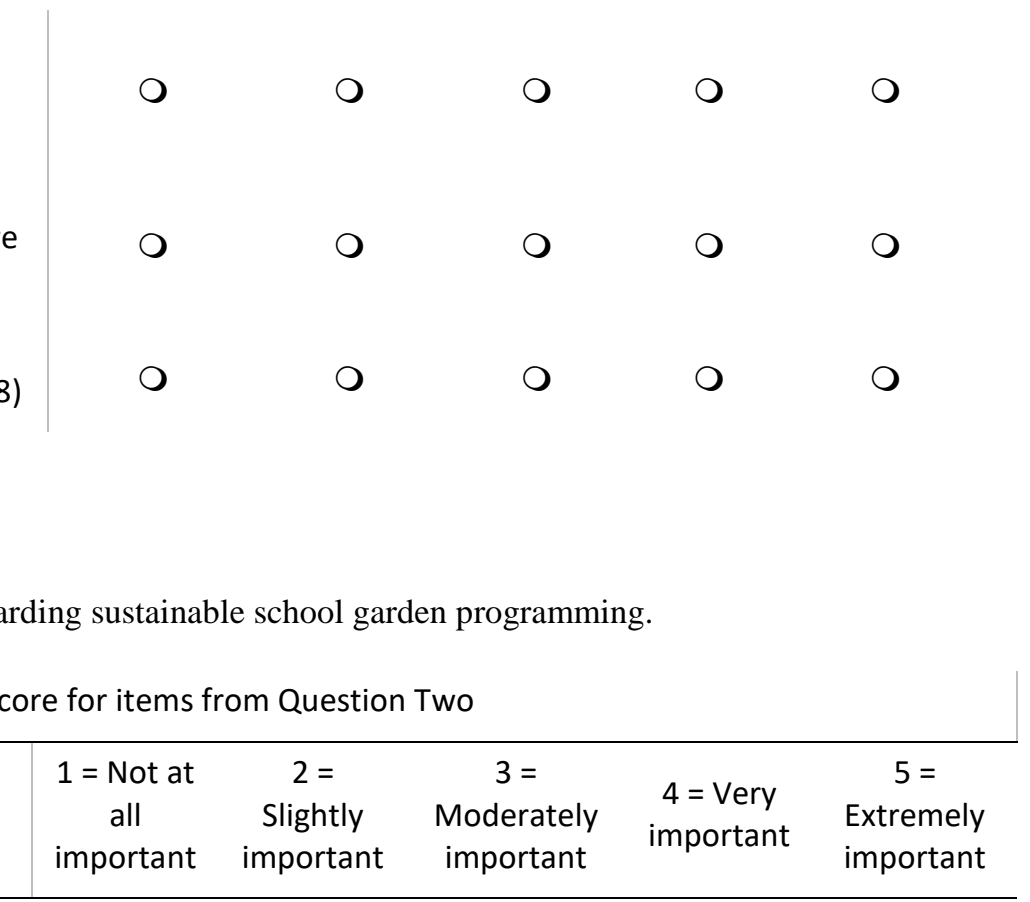

Re-rate or keep score for items from Question Two

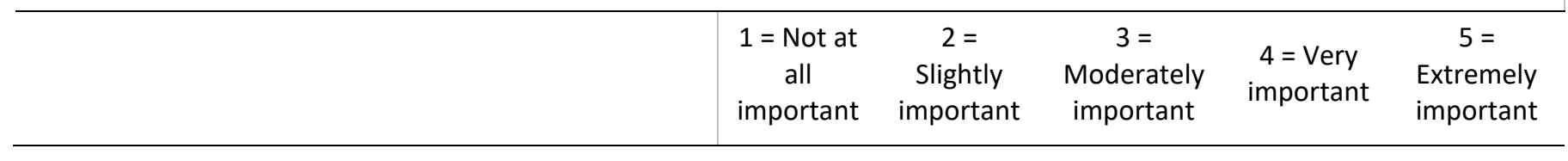


Responsibilities delegated throughout the school community. (Average Group Score $=3.5$ )

Involving cafeteria staff support to help incorporate new foods. (Average Group Score $=3$ )

Involving community members and neighbors to help take care of the garden. (Average Group Score $=3.3$ )

Involving parents and families to help take care of the garden. (Average Group Score = 3.7)

Buy-in and commitment from parents and families.

$$
\text { (Average Group Score }=3.8 \text { ) }
$$

Buy-in and commitment from the community partners and volunteers. (Average Group Score $=3.3$ )

Collaboration between the networks of stakeholders. (Average Group Score $=3.5$ )

Creating a realistic, multi-year budget for the whole program. (Average Group Score $=3.6$ )

An accessible and realistic multi-year budget for the program that is supported by the school community.

(Average Group Score = 3.4)

An accessible and realistic multi-year budget for the program that is supported by the local community partners. (Average Group Score $=3.3$ )

Volunteers to use and maintain the garden during the summer. (Average Group Score = 3.7)

Opening the garden to community members for events, work-days, markets, etc. (Average Group Score $=3.6)$

Creating a schedule for garden access, including nongrowing months. (Average Group Score $=3.6$ )

To collaborate with after-school programs to promote garden clubs to help with garden maintenance.

(Average Group Score $=3.8$ )

Having a yearlong instructional plan that is relevant and a part of the overall school curriculum. (Average Group Score $=3.8$ )

Having a clear, easy to follow, standards-based curriculum. (Average Group Score $=3.8$ )

To design space and plantings so that growth occurs in phases throughout the school year to help decipher realistic yearly maintenance. (Average Group Score = 
To add at least one new and exciting element each year, such as growing new items, raising bees, etc. (Average Group Score $=3.2$ ) 
The following items have been identified in school garden literature as potential benefits of the school garden. Please rank these items in order of importance or add your own response to the list.

Increases fruit and vegetable consumption

Increases

physical activity

Increases

attachment, pride, and belonging to school

Increases

academic

performance and

achievement

Encourages conservation and ecological commitment

Encourages cooperative group learning and teamwork

\section{Encourages} parental involvement

Enhances school curriculum

Heightens student motivation and enthusiasm

Improves student sense of self

Creates a sense of ownership

$\begin{array}{ccccc}1=\text { Not at all } & 2=\text { Slightly } & 3=\text { Moderately } & 4=\text { Very } & 5=\text { Extremely } \\ \text { important } & \text { important } & \text { important } & \text { important } & \text { important }\end{array}$

$1=$ Not at all

important

O

O

O

O

O

$\bigcirc$

$\mathrm{O}$

O

O

O

O

○

o

O

O

o

O

○ 


\begin{tabular}{|c|c|c|c|c|c|}
\hline $\begin{array}{l}\text { Empowers } \\
\text { students to } \\
\text { change their } \\
\text { community }\end{array}$ & O & 0 & 0 & 0 & $\mathrm{O}$ \\
\hline $\begin{array}{l}\text { Introduces } \\
\text { students to the } \\
\text { scientific } \\
\text { methods of } \\
\text { farming and } \\
\text { food production }\end{array}$ & $\mathrm{O}$ & $O$ & 0 & 0 & $\mathrm{O}$ \\
\hline $\begin{array}{l}\text { Contributes } \\
\text { towards food } \\
\text { security }\end{array}$ & 0 & 0 & 0 & 0 & 0 \\
\hline $\begin{array}{l}\text { Improves the } \\
\text { quality of } \\
\text { teaching }\end{array}$ & 0 & 0 & 0 & 0 & 0 \\
\hline $\begin{array}{c}\text { Enter } \\
\text { statement: }\end{array}$ & 0 & 0 & 0 & 0 & 0 \\
\hline $\begin{array}{c}\text { Enter } \\
\text { statement: }\end{array}$ & 0 & 0 & $O$ & 0 & 0 \\
\hline $\begin{array}{c}\text { Enter } \\
\text { statement: }\end{array}$ & O & 0 & 0 & $\mathrm{O}$ & 0 \\
\hline
\end{tabular}

End of Block: Consensus Building Round Three Survey 


\section{Appendix J: Semi-Structured Mini-Focus Groups and Interview Guide}

Interviewer Introduction: Thank you for agreeing to participate in this study and committing your time and expertise, it is greatly appreciated. I thank you for your patience throughout this process. The purpose of today's interview is to further develop and discuss the results of the 3 round Delphi study you just completed.

By participating in this research, you will help capture and understand the benefits of school garden programming, as well as the recommendations for starting and sustaining a program. This study has been reviewed and acknowledged by the institution of institutional review board of West Virginia University.

Your participation in this research is completely voluntary. You may skip any question that you do not wish to answer and you may discontinue at any time. Your responses will be confidential. This interview will be audiotaped. If at any time you do not wish for your comments to be recorded then the recorder can be turned off at any time. Information from this interview will be used for program research and publications and will not identify any of the participants by name. There are no known risks to participation.

Are there any questions before we begin?

First let's start with a few background questions.

\section{Demographics:}

1) What is your role in school garden programming in DC?

2) How long have you been involved in school garden programming?

\section{Interview Questions:}

1) From the Rounds of the Delphi study, we found consensus on three different research questions. The first regarding the startup of a school garden, the second regarding the sustainability, and the third regarding the potential benefits. If you would, please share with the group your thoughts regarding the results of this study.

2) What do you perceive to be the benefits of school garden programming?

a. Can you tell me a story about a personal experience?

3) What are your recommendations for schools looking to start a school garden program?

4) What are your recommendations for school garden sustainability?

5) In order to progress the school garden movement throughout the nation with the idea of every school should have a garden, what do you think needs to happen? 


\section{Appendix K: Thematic Coding for Round 1 Question 1 Statements}

\begin{tabular}{|c|c|c|c|}
\hline & Code & Responses & Short Descriptor \\
\hline 1 & $\begin{array}{l}\text { Support } \\
\text { Partnerships }\end{array}$ & $\begin{array}{l}\text { Involve as many stakeholders as possible -- } \\
\text { administration, parents, teachers, students, cafeteria } \\
\text { staff, neighbors, etc. }\end{array}$ & Many stakeholders \\
\hline 2 & Accessibility & Accessible to students, staff, and parents & $\begin{array}{l}\text { to students, staff, } \\
\text { and parents }\end{array}$ \\
\hline 3 & Infrastructure & space for garden & Space \\
\hline 4 & $\begin{array}{l}\text { Planning } \\
\text { Infrastructure }\end{array}$ & $\begin{array}{l}\text { design your site to fit your needs (just because you } \\
\text { have space doesn't mean you need to fill it up) }\end{array}$ & Space-design \\
\hline 5 & Support & community support & community \\
\hline 6 & $\begin{array}{l}\text { Planning } \\
\text { Interest/Buy-in } \\
\text { Partnerships }\end{array}$ & $\begin{array}{l}\text { Ask for input from the community from the onset of } \\
\text { the project instead of asking for feedback after you } \\
\text { have already started establishing part of the project. }\end{array}$ & $\begin{array}{l}\text { Community } \\
\text { partners }\end{array}$ \\
\hline 7 & Accessibility & Not accessible to those not affiliated with the school & community \\
\hline 8 & Support & administrative support & administration \\
\hline 9 & $\begin{array}{l}\text { Planning } \\
\text { Support }\end{array}$ & carefully consider staffing, garden use, and funding & Staffing; funding \\
\hline 10 & Planning & strate & Ove \\
\hline $\begin{array}{l}11 \\
12\end{array}$ & $\begin{array}{l}\text { Accessibility } \\
\text { Support }\end{array}$ & $\begin{array}{l}\text { Accessible during school hours } \\
\text { funds for tools and seeds }\end{array}$ & $\begin{array}{l}\text { During school hrs. } \\
\text { funding }\end{array}$ \\
\hline 13 & $\begin{array}{l}\text { Interest/Buy-in } \\
\text { Support } \\
\text { Partnerships }\end{array}$ & $\begin{array}{l}\text { have multiple stakeholders in from as many parts of } \\
\text { the school community as possible (teachers, admin, } \\
\text { parents/PTO) }\end{array}$ & $\begin{array}{l}\text { Many stakeholders; } \\
\text { partners }\end{array}$ \\
\hline 14 & Education & $\begin{array}{l}\text { educate our youth how most foods, especially } \\
\text { produce are grown }\end{array}$ & students \\
\hline 15 & Buy-in & Secure a site with actively engaged participant & From \\
\hline 16 & $\begin{array}{l}\text { Sustainability } \\
\text { Planning }\end{array}$ & $\begin{array}{l}\text { Having a clear understanding/agreement between the } \\
\text { school and partners on the size, initial cost, } \\
\text { maintenance costs and possible plans for expansion of } \\
\text { the program to ensure that there is the preparation for } \\
\text { a multi-year investment and that schools/partners do } \\
\text { not feel overwhelmed by the maintenance. }\end{array}$ & $\begin{array}{l}\text { School/partner } \\
\text { agreements }\end{array}$ \\
\hline 17 & $\begin{array}{l}\text { Support } \\
\text { Resources }\end{array}$ & Startup funds/materials & $\begin{array}{l}\text { Funding and } \\
\text { resources }\end{array}$ \\
\hline 18 & Resources & $\begin{array}{l}\text { Contact school district to inquire about } \\
\text { services/resources available. }\end{array}$ & $\begin{array}{l}\text { Available resources } \\
\text { to help }\end{array}$ \\
\hline 19 & Support & Principle and staff support & Admin and staff \\
\hline 20 & $\begin{array}{l}\text { Support } \\
\text { Partnerships }\end{array}$ & $\begin{array}{l}\text { Embrace the parental community/organizations to } \\
\text { lend support. }\end{array}$ & Community/parents \\
\hline 21 & $\begin{array}{l}\text { Interest/Buy-in } \\
\text { Support } \\
\text { Sustainability } \\
\text { Partnerships } \\
\text { Education }\end{array}$ & $\begin{array}{l}\text { there is a group of invested participants who will not } \\
\text { quickly roll over, who are committed to the } \\
\text { administrative, educational and upkeep aspects of the } \\
\text { project }\end{array}$ & $\begin{array}{l}\text { Invested } \\
\text { stakeholders; } \\
\text { partners }\end{array}$ \\
\hline
\end{tabular}


22 Interest/Buy-

23 Interest/Buy-in Planning

24 Interest/Buy-in

25 Support Partnerships

26 Planning Infrastructure

Resources

27 Support

28 Planning

29 Support

30 Planning

31 Interest/Buy-in

32 Planning

33 Interest/Buy-in

34 Infrastructure Resources

35 Support

36 Support

37 Support Interest/Buy-in

38 Support

39 Planning

40 Interest/Buy-in

41 Support Infrastructure

42 Support

43 Education Infrastructure

44 Support Interest/Buy-in

45 Education
An enthusiastic team

team

Ask school faculty/admin to gather interest in school gardens

Interested parents

Engage with community partners to lend support.

that a garden makes sense on the available land and that we are not trying to fit a garden in a space that is not made for it (i.e. picking what kind of garden makes sense for the location and available resources)

Administrator support

Start small

Make sure that the school administration understands the value of the program and wholeheartedly supports it before you begin.

Plan on where you want the garden to be. Location

Buy-in from school leadership and teachers

Start small

Make sure you have the school community's buy-in involvement and participation from the school

What do you need for your garden? Tools, Soil, and Materials

support from an organization with experience in installing gardens

Find your local network of experts

Ensure you have parent support and create excitement

via workdays and garden celebrations

Who will be involved in keeping the garden?

Volunteers must be committed (students, staffs, and parents)

clear mission/ vision of program

Celebrate often

A dedicated, knowledgeable, skilled coordinator

staff to support it

Hire a full-time horticulture teacher/registered

horticultural therapist with graduate-level education

in horticulture, agricultural extension education, human services and at least two years' experience using those elements together in educational programming and delivery.

Ensure top-down buy-in from the principal or district or work to build this support.

To educate the students the importance of plants in students our lives.
From all involved

parents

Community

partners

Planning to fit

space and resources

administration

Beginning planning

administration

location

Admin/teachers

Beginning planning

Community and

school

Materials and

resources

Community

experts

parents

volunteers

Mission/vision

celebrate

coordinator

staff

Specialized teacher

Principal/district 
46 Interest/Buy-in

47 Resources

48 Support

49 Education

50 Education

51 Resources

52 Planning Infrastructure

53 Support Infrastructure

54 Education

55 Support

56 Support Interest/Buy-in

57 Planning

58 Partnerships

59 Education Interest/Buy-in

60 Partnerships

61 Education Resources

62 Education Interest/Buy-in

63 Planning

64 Support Infrastructure
Buy in from the school community (parents, leadership, teachers, students)

materials

An accessible annual budget for the program that is no less than $\$ 10,000.00$ for equipment and materials. This implies the unfailing support of the school administrator - from the very top on down to the teachers and paraprofessionals.

Provide research to teachers/parents about the benefits of school gardens.

To give them an outdoor experience with hands-on activities with nature

access to sufficient resources

plan and location

A budget in facilities operations to support the installation of accessible raised beds, irrigation systems (just under the surface hard pipe drip) that are on an accessible timer, high porosity soilless growing medium, and the proper growing environment (whether outdoors, indoors, using conventional in-ground planting or aquaponics. To engage them with the important knowledge to explore more by tasting the produce they have grown locally instead of buying from a market

Administrative Support Enfranchise parents and faculty and get them to help with the actual gardening alongside students start small

Allies within the teachers - passionate gardeners

Generate enthusiasm by connecting the garden with relevant coursework in as many grades as possible make sure there is a team - don't let one enthusiastic person be labeled "the school garden person."

Knowledge of where to find resources (especially free)

Grow something students can harvest and eat as early as possible in the program to generate excitement for the project

be clear about goals and link them to school goals

Start with manageable size, budget and community support
All involved

materials

Funding, administration

Educating teachers/parents students

Sufficient resources Plan and location

Funding to support needed infrastructure

Students/parents

administrative

Parents and faculty

Teachers and gardeners

Teachers and students team

Finding resources

Students/parents

The program aligns with school goals Space, funding, support 


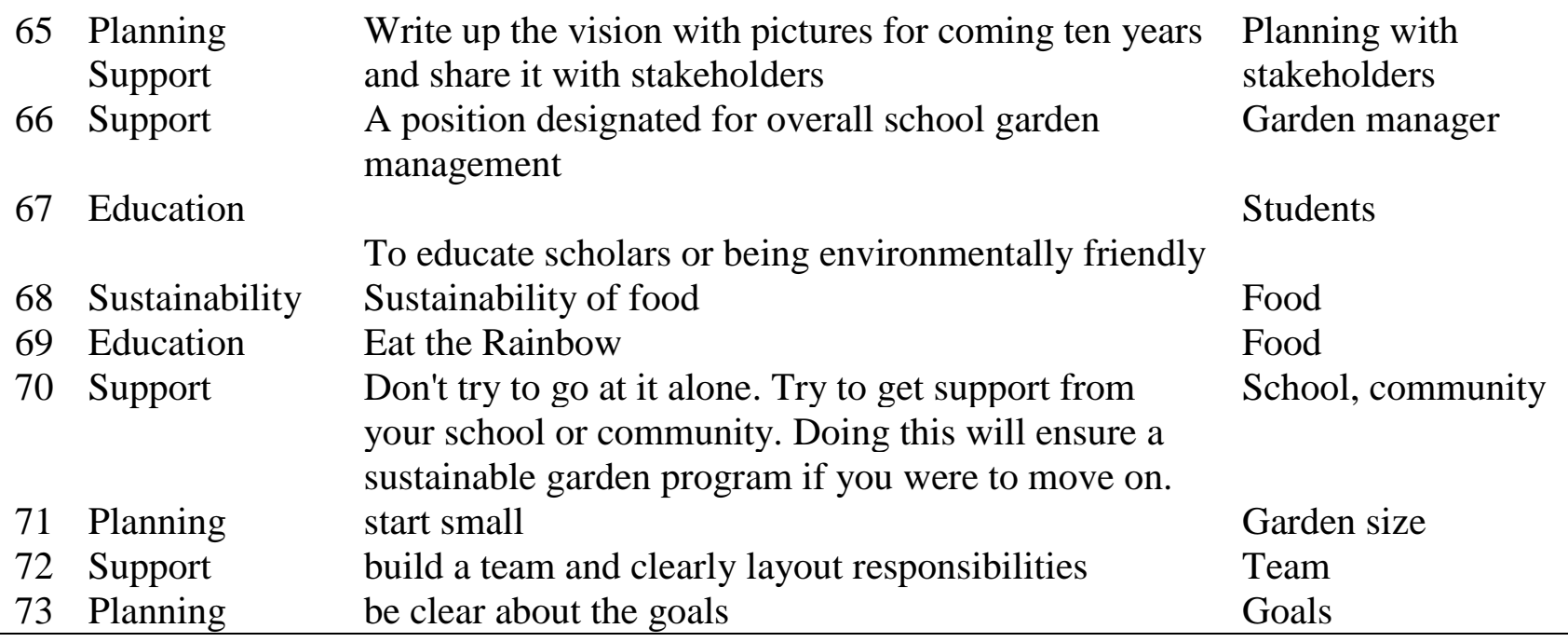




\section{Appendix L: Thematic Coding for Round 1 Question 2 Statements}

\begin{tabular}{|c|c|c|c|}
\hline & Code & Responses to Question 2 & Short Descriptor \\
\hline 1 & $\begin{array}{l}\text { Interest/Buy-In } \\
\text { Education } \\
\text { Partnerships }\end{array}$ & $\begin{array}{l}\text { Community buy-in from various stakeholders. } \\
\text { Involve teachers so that the school garden places } \\
\text { to read or learn math. Involve cafeteria staff so } \\
\text { that the garden is a place to grow new foods to try. } \\
\text { Involve neighbors and parents so that various } \\
\text { people will take care of the garden. Involve } \\
\text { students so that there is clear ownership with them } \\
\text { as they move up grades in the school. }\end{array}$ & $\begin{array}{l}\text { Various } \\
\text { stakeholders; } \\
\text { Education }\end{array}$ \\
\hline 2 & Support & An expert on how to manage the garden & Garden coordinator \\
\hline 3 & Support & administrative support & Administration \\
\hline 4 & Support & $\begin{array}{l}\text { staffing--someone ultimately responsible for the } \\
\text { upkeep of the garden }\end{array}$ & Garden coordinator \\
\hline 5 & Maintenance & periodic soil testing & Soil \\
\hline 6 & Maintenance & Seeds/plants/resources to maintain the garden & Resources \\
\hline 7 & Resources & regular source of funding & Funding \\
\hline 8 & Maintenance & drip irrigation & Irrigation \\
\hline 9 & Support & school-wide support & School community \\
\hline 10 & Accessibility & A schedule for when/who can access the garden & Schedule \\
\hline 11 & Support & dedicated school garden coordinator & Garden coordinator \\
\hline 12 & Education & $\begin{array}{l}\text { making garden education relevant and a part of the } \\
\text { overall school curriculum }\end{array}$ & Curriculum \\
\hline 13 & Support & Consistent funding stream. & Funding \\
\hline 14 & $\begin{array}{l}\text { Support } \\
\text { Maintenance } \\
\text { Resources } \\
\text { Planning } \\
\text { Partnerships }\end{array}$ & $\begin{array}{l}\text { Creating a realistic multi-year budget for the } \\
\text { whole program (maintenance and staffing) and } \\
\text { sharing it with all partners including school } \\
\text { administration. If possible having some of the } \\
\text { costs covered by the school or PTA budget. Not } \\
\text { have it all dependent on outside grants. }\end{array}$ & $\begin{array}{l}\text { Funding for } \\
\text { maintenance and } \\
\text { staffing; } \\
\text { admin/PTA help }\end{array}$ \\
\hline 15 & $\begin{array}{l}\text { Interest/Buy-In } \\
\text { Partnerships }\end{array}$ & An enthusiastic team & Team \\
\hline 16 & Support & Faculty or parent point of contact for program & Coordinator \\
\hline 17 & Support & $\begin{array}{l}\text { One needs to have a garden coordinator to manage } \\
\text { the garden. The teachers are not able to manage it } \\
\text { and do their jobs. }\end{array}$ & Garden coordinator \\
\hline 18 & Support & $\begin{array}{l}\text { Delegating responsibilities throughout the school } \\
\text { community. }\end{array}$ & School community \\
\hline 19 & $\begin{array}{l}\text { Maintenance } \\
\text { Planning }\end{array}$ & $\begin{array}{l}\text { Growing the garden in phases to be able to } \\
\text { decipher best how much maintenance is } \\
\text { realistically doable for the group/school. }\end{array}$ & $\begin{array}{l}\text { Garden } \\
\text { maintenance and } \\
\text { planning }\end{array}$ \\
\hline 20 & Support & Administrator support & Administration \\
\hline 21 & Resources & Resources available on a continuous basis & Resources \\
\hline
\end{tabular}


22 Partnerships

Support

Interest/Buy-In

23 Support

24 Planning

Education

Accessibility

25 Education

26 Interest/Buy-In

27 Partnerships

Accessibility

28 Support

29 Education

Support

30 Support

31 Support

Partnerships

32 Support

33 Education

34 Support

35 Support

36 Support

Interest/Buy-In

37 Support

38 Interest/Buy-In

39 Partnerships Support

40 Support

41 Support

$42 \quad$ Planning Resources

43 Education
Engage with the after-school program to see if there is interest in having a garden club help do the work The more the students work in the garden, the more respect they have for space.

Designating one or two garden coordinators.

Establishing and dedicating time to growing the ways the garden is incorporated into the school culture and learning.

Clear, easy to follow, standards-based curriculum participants' interest

Engage with local community members to

possibly use the garden during the summer months.

All the grades and teachers and parents have to be involved and committed

clear connections to priorities of the school

(integrated into school's culture)

Supportive administration

Student involvement via garden clubs, after-school activities

staffing - school garden programs cannot rely on professional development for the teaching staff and then expect them to run it on their own - you need dedicated staff for the garden

Have a lesson plan towards what you want the kids to learn.

staffing

Supportive teachers

Administrative support - financially and in

encouraging teachers to spend time outdoors with students

funding for staffing

Take turns so everyone can participate equally to make it fun and interesting.

Being a part of a network.

Supportive families

a dedicated, knowledgeable, skilled, creative, resourceful coordinator

Well-organized plan and materials

Training for teachers about incorporating the garden as an outdoor classroom.
After-school

program; students

Garden

coordinators

Time; school

culture and learning

Curriculum

Participants

Community

members; summer

Parents

School culture

Administration

Students; afterschool programs

Teachers and staff

Teachers;

curriculum

Staff

Teachers

Administration;

teachers

Staff

Everyone involved

Network

Families

Coordinator

Plan and materials

Teachers 
44 Support

45 Interest/Buy-In

46 Support

Partnerships

47 Support

Maintenance

48 Infrastructure

Resources

49 Resources

50 Support

Education

Infrastructure

51 Support

Education

Infrastructure

52 Support

Infrastructure

Maintenance

53 Support

54 Support

55 Infrastructure

Planning

56 Interest/Buy-In

57 Support

58 Planning Interest/Buy-In

Accessibility

59 Education
Commitment from the teachers, administration, parents volunteers and community helpers

buy in from the entire school community

The whole school and community support and participation

A coordinator to oversee the maintenance of space and delegate tasks as needed.

Logistics, infrastructures like arable land, water supply, Supplies based on the age group of the students and good communication skills

access to sufficient resources

The background knowledge about the gardening and sustainable development of how eating local

will help reduce the cost of production and

pollution levels etc. and make a connection it grow

foods in the garden

Hire a full-time horticulture teacher/registered

horticultural therapist with graduate-level

education in horticulture, agricultural extension

education, human services and at least two years'

experience using those elements together in

educational programming and delivery.

A budget in facilities operations to support the

installation of accessible raised beds, irrigation

systems (just under the surface hard pipe drip) that

are on an accessible timer, high porosity soilless

growing medium, and the proper growing

environment (whether outdoors, indoors, using

conventional in-ground planting or aquaponics.

An accessible annual budget for the program that

is no less than $\$ 10,000.00$ for equipment and materials. This implies the unfailing support of the school administrator - from the very top on down to the teachers and paraprofessionals.

Administrative Support

Designing your plantings, so something is growing for as much of the school year as possible

buy in from school leadership

Garden Coordinator

Planning how you will engage students in the nongrowing months and on days when you cannot be outside

integration with curriculum - used by teachers

during the school day
Teachers, admin, parents, volunteers, community

School community

School and

community

Coordinator

Land and resources, supplies

Resources

Specialized teacher

Specialized teacher

Funding to support infrastructure

Funding;

administration

Administration

Growing design

Administration

Coordinator

Teachers; students

Curriculum 


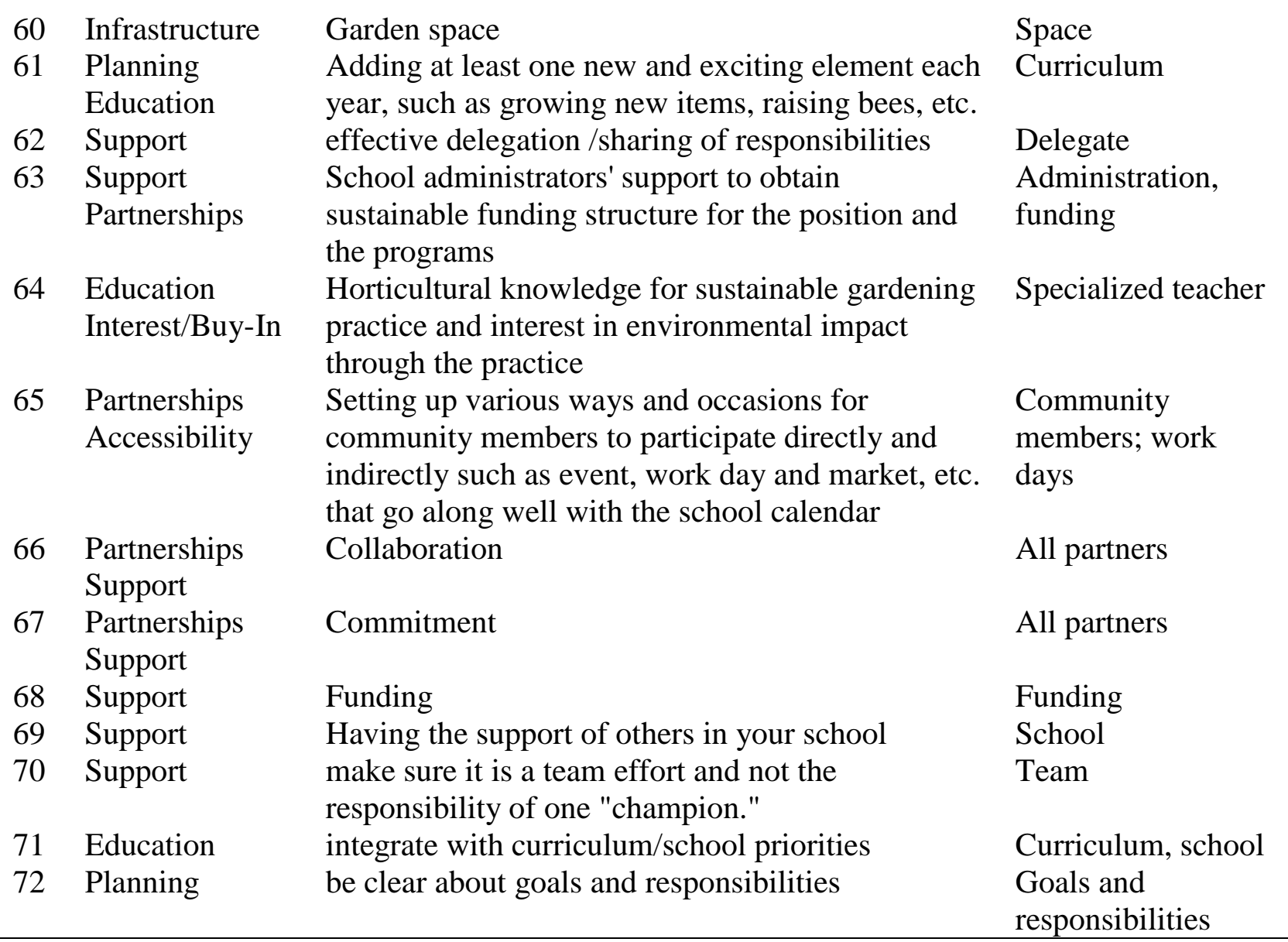




\section{Appendix M: Round 1 Question 1 synthesized statements}

1. Ensuring top-down buy-in from the school district and administration to build support.

2. Engaging a group of invested community partners who are committed to the administrative, educational and upkeep aspects of the project long-term.

3. Hiring a full-time horticulture teacher or registered horticulture therapist.

4. Establishing a team and a network of partners with clearly laid out responsibilities.

5. Hiring a dedicated, knowledgeable skilled coordinator.

6. Having a position designated for overall school garden management.

7. Buy-in from multiple stakeholders in the school community (teachers, students, school staff, and PTA).

8. Embracing the parental community to lend support and encouraging them to help with gardening alongside students.

9. Gaining support from community partners that assist with development and installation of the garden in the available school space.

10. Securing start-up funding for garden development, equipment, and materials.

11. Ensuring garden access to students, staff, and parents during school hours.

12. Ensure garden access to community members after school hours.

13. Securing a site with actively engaged participants and an enthusiastic team.

14. Ensuring parent interest and support via workdays and garden celebrations.

15. Generating student enthusiasm by connecting the garden with students' coursework.

16. Celebrating garden program achievements often.

17. Contacting school district to inquire about services/resources available.

18. Knowing where to find free resources and educational materials.

19. Having a plan for the available space, resources, and materials that are available.

20. Starting with a manageable size.

21. Creating a budget in facilities operations to support maintenance of the different growing structures.

22. Having an agreement with the school and all stakeholders on the size, initial cost, maintenance cost, and future plans of the garden.

23. Ensuring stakeholders understand and are prepared to fund a multi-year investment.

24. Gathering input from the community at the onset of the project rather than ask for feedback once plans are developed.

25. Creating clear goals and linking them to the schools goals.

26. Developing a vision with pictures for the coming 10 years and share it with stakeholders

27. Developing a multi-year strategic plan that includes development, maintenance, staffing, instructional goals, and budget.

28. Educating the students on food and nutrition and the importance of growing and eating local produce.

29. Providing the students with an outdoor experience with hands-on activities in nature.

30. Connecting the garden with program activities with content standards across the curriculum.

31. Growing something students can harvest and eat as early as possible in the program.

32. Providing research to teachers/parents about the benefits of school gardens. 


\section{Appendix N: Round 1 Question 2 synthesized statements}

1. Involving cafeteria staff support to help incorporate new food

2. Hiring a full-time, knowledgeable coordinator to manage and maintain the school garden program.

3. Responsibilities delegated throughout the school community.

4. Involving cafeteria staff support to help incorporate new foods.

5. Involving community members and neighbors to help take care of the garden.

6. Involving parents and families to help take care of the garden.

7. Buy-in and commitment from the school administration.

8. Buy-in and commitment from the teachers and staff.

9. Creating a sense of ownership with the students.

10. Buy-in and commitment from parents and families.

11. Buy-in and commitment from the community partners and volunteers.

12. Collaboration between the networks of stakeholders.

13. Having an enthusiastic team.

14. Creating a realistic, multi-year budget for the whole program.

15. An accessible and realistic multi-year budget for the program that is supported by the school community.

16. An accessible and realistic multi-year budget for the program that is supported by the local community partners.

17. Volunteers to use and maintain the garden during the summer.

18. Opening the garden to community members for events, work-days, markets, etc.

19. Creating a schedule for garden access, including non-growing months.

20. Involving all grades and teachers in the garden.

21. To connect the priorities of the garden program to those of the school and school culture.

22. To collaborate with after-school programs to promote garden clubs to help with garden maintenance.

23. Having a yearlong instructional plan that is relevant and a part of the overall school curriculum.

24. Having a clear, easy to follow, standards-based curriculum.

25. Providing training for teachers on how to incorporate the garden as an outdoor classroom.

26. Ensuring that supplies and materials are well-organized and are based on the age group of the students.

27. Having continual access to materials (seeds, plants, soil) to maintain the garden.

28. To design space and plantings so that growth occurs in phases throughout the school year to help decipher realistic yearly maintenance. 


\section{Appendix O: Sample data from interviews, successful school garden start-up}

\begin{tabular}{|c|c|c|c|}
\hline Theme & Subtheme & $\mathrm{n}$ & Sample Data \\
\hline \multirow[t]{2}{*}{ Buy-In } & $\begin{array}{l}\text { Proof of impact } \\
\text { of garden }\end{array}$ & $\begin{array}{l}\text { P1, P2, } \\
\text { P3, P4, } \\
\text { P5 }\end{array}$ & $\begin{array}{l}\text { "I think we need to show the success in the same } \\
\text { ways that people in the rest of the education field are } \\
\text { showing data." (G1-P1) } \\
\text { "I talk a lot about the academic benefits because } \\
\text { that's what teachers are assessed on and that's what } \\
\text { principals look at. That's what they get pay } \\
\text { increases for... their jobs are on the line for that kind } \\
\text { of stuff." (G2-P3) }\end{array}$ \\
\hline & $\begin{array}{l}\text { School staff and } \\
\text { administration }\end{array}$ & $\begin{array}{l}\text { P1, P3, } \\
\text { P4, P5, } \\
\text { P6 }\end{array}$ & $\begin{array}{l}\text { "The highest priority for making school gardens } \\
\text { work is just simply buy-in from the school." (G1- } \\
\text { P1) } \\
\text { "It has to come from the administrators to legitimize } \\
\text { my presence." (G3-P5) }\end{array}$ \\
\hline \multirow[t]{4}{*}{ Planning } & Team and vision & $\begin{array}{l}\text { P1, P2, } \\
\text { P4, P5 }\end{array}$ & $\begin{array}{l}\text { "Definitely start with something that you know can } \\
\text { be maintained and then immediately start coming up } \\
\text { with a plan for how the school garden is not a one- } \\
\text { person project." (G1-P2) }\end{array}$ \\
\hline & Size and design & $\begin{array}{l}\text { P1, P2, } \\
\text { P6, P7 }\end{array}$ & $\begin{array}{l}\text { "It's also just about design and trying to go to the } \\
\text { stakeholders, talk to the teachers talk to the students, } \\
\text { how are you going to use the space?" (G1-P1) } \\
\text { "I was surprised that the manageable size scored } \\
\text { kind of low because I think for us that was really } \\
\text { important, that we could start small and build it as } \\
\text { we needed to." (G4-P6) }\end{array}$ \\
\hline & $\begin{array}{l}\text { Funding, } \\
\text { materials, and } \\
\text { resources }\end{array}$ & $\begin{array}{l}\text { P1, P2, } \\
\text { P3, P4, } \\
\text { P6 }\end{array}$ & $\begin{array}{l}\text { "Funding is number 1." (G2-P4) } \\
\text { Funding is extremely important to have a suitable } \\
\text { program." (G2-P3) }\end{array}$ \\
\hline & $\begin{array}{l}\text { School } \\
\text { curriculum and } \\
\text { goals }\end{array}$ & $\begin{array}{l}\text { P1, P2, } \\
\text { P3, P4, } \\
\text { P5, P6, } \\
\text { P7 }\end{array}$ & $\begin{array}{l}\text { "There's high importance of imbedding this within } \\
\text { the curricular goals and I think treating the garden as } \\
\text { a resource that is important to incorporate within } \\
\text { those already existing classes." (G2-P3) } \\
\text { "This has to be one of the priorities for the leaders to } \\
\text { have Science as a part of the curriculum." (G3-P5) }\end{array}$ \\
\hline \multirow[t]{2}{*}{ Support } & $\begin{array}{l}\text { Garden } \\
\text { coordinator/point } \\
\text { person }\end{array}$ & $\begin{array}{l}\text { P1, P2, } \\
\text { P3, P4, } \\
\text { P5, P6, } \\
\text { P7 }\end{array}$ & $\begin{array}{l}\text { "I do think having a paid role, if it's regular school } \\
\text { teacher who gets an extra stipend for being the } \\
\text { person who can keep track of what is in the } \\
\text { garden... or who to call for what to do." (G1-P2) }\end{array}$ \\
\hline & Policy & $\begin{array}{l}\text { P1, P2, } \\
\text { P3, P5 }\end{array}$ & $\begin{array}{l}\text { "You guys, up there in the policy world, are } \\
\text { constantly running your mouth about how we need } \\
\text { to do this better and we need to do that better, if you } \\
\text { really believe it, well, put your money where your } \\
\text { mouth is because we have the data to show that we } \\
\text { can do it." (G1-P1) }\end{array}$ \\
\hline
\end{tabular}




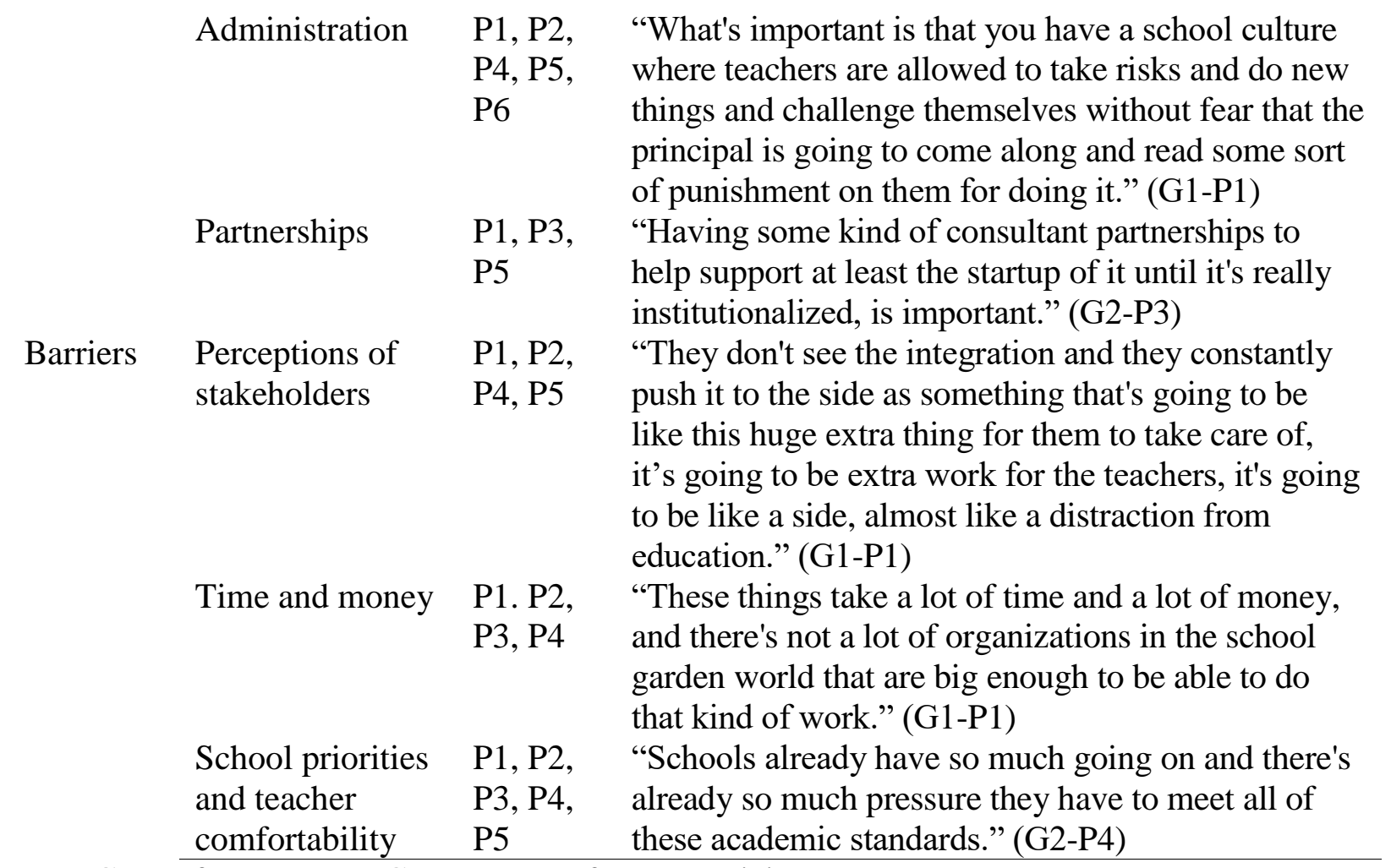

Note. $\mathrm{G}$ - Refers to Focus Group, $\mathrm{P}$ - Refers to Participant 


\section{Appendix P: Sample data from interviews, sustainability of school garden programs}

\begin{tabular}{|c|c|c|c|}
\hline Theme & Subtheme & $\mathrm{n}$ & Sample Data \\
\hline \multirow[t]{2}{*}{$\begin{array}{l}\text { School } \\
\text { Goals }\end{array}$} & School Culture & $\mathrm{P} 1, \mathrm{P} 2$ & $\begin{array}{l}\text { "Sustainability of the school garden remaining a } \\
\text { part of the school culture is really central to what } \\
\text { we do because when we invest all that time and } \\
\text { money we want to make sure that by the time we } \\
\text { kind of walk away that we have empowered } \\
\text { teachers and that we've really made the school } \\
\text { garden a big part of the core of that school's } \\
\text { identity." (G1-P1) }\end{array}$ \\
\hline & $\begin{array}{l}\text { Curriculum } \\
\text { Integration }\end{array}$ & $\begin{array}{l}\text { P1, P2, } \\
\text { P4 }\end{array}$ & $\begin{array}{l}\text { "You could have a "successful school garden } \\
\text { program" that is not super integrated into the } \\
\text { school, as long as it is integrated in some other } \\
\text { component of the school." (G1-P2) } \\
\text { "It has to be taught in the classroom also. Like } \\
\text { regular classroom also." (G3-P5) }\end{array}$ \\
\hline \multirow[t]{5}{*}{ Support } & $\begin{array}{l}\text { Garden } \\
\text { Coordinator }\end{array}$ & $\begin{array}{l}\text { P1, P2, } \\
\text { P3, P4, } \\
\text { P6 }\end{array}$ & $\begin{array}{l}\text { "If he were to leave, you know, yeah, we would } \\
\text { have to find someone else who cares deeply } \\
\text { enough to do that or it would in fact, kind of die } \\
\text { out." (G4-P6) } \\
\text { "Like a point person that has some logistical skill } \\
\text { and reliability and I think that it's important that } \\
\text { that person is not simply a volunteer because } \\
\text { volunteers it's more likely that a volunteer is going } \\
\text { to leave." (G1-P2) }\end{array}$ \\
\hline & $\begin{array}{l}\text { Teachers and } \\
\text { Administration }\end{array}$ & $\begin{array}{l}\text { P1, P2, } \\
\text { P3, P4, } \\
\text { P5 }\end{array}$ & $\begin{array}{l}\text { "I think that that administrator position needs to be } \\
\text { less passive and more active, as in you would } \\
\text { never hire a teacher that doesn't have experience." } \\
\text { (G2-P3) }\end{array}$ \\
\hline & $\begin{array}{l}\text { Parents and } \\
\text { Families }\end{array}$ & $\begin{array}{l}\text { P3, P4, } \\
\text { P5, P6, } \\
\text { P7 }\end{array}$ & $\begin{array}{l}\text { "Parents that I have been able to work with I just } \\
\text { think that they have been really crucial in } \\
\text { furthering the programs." (G2-P4) } \\
\text { "PTO is undeniably a great support." (G3-P5) } \\
\text { "We do have some parents who have come and } \\
\text { said I would love to help with this so they come } \\
\text { and help with some weeding, especially in the } \\
\text { summer when we don't have students around." } \\
\text { (G4-P6) }\end{array}$ \\
\hline & Partnerships & $\begin{array}{l}\text { P1, P2, } \\
\text { P3, P4, } \\
\text { P5, P6 }\end{array}$ & $\begin{array}{l}\text { "Ideals for sustainability is to have that luxury of } \\
\text { being able to work with people that can coach you } \\
\text { for a long period of time until you're ready to kind } \\
\text { of fly off on your own." (G1-P1) }\end{array}$ \\
\hline & $\begin{array}{l}\text { Values and } \\
\text { Commitment }\end{array}$ & $\begin{array}{l}\text { P1, P2, } \\
\text { P5, P6 }\end{array}$ & $\begin{array}{l}\text { "This can be done but we need more } \\
\text { commitment." (G3-P5) }\end{array}$ \\
\hline
\end{tabular}


"The things that are important for getting a school garden going and sustaining it really goes back to how important do we think those values are." (G1P1)

Funding, Design, $\quad$ P1, P2, "Having a really good design from the beginning and Maintenance P3, P4, before you break ground as opposed to just kind of P6, P7 like jumping right in, I think it pays off in terms of sustainability." (G1-P1)

Barriers Money, Resources, P1, P2, "Budget is a concern. Budget includes the salary Time $\mathrm{P} 3, \mathrm{P} 4$ that would pay the coordinator." (G1-P2)

"It's easy to have started garden but it's really hard to keep it maintained and money and as part of the school." (G2-P4)

Curriculum

P3, P4, Integration $\mathrm{P} 5$ "I find that programs that don't incorporate the school day work and the coursework into the program they have a really hard time sustaining themselves." (G2-P3)

Point

$\mathrm{P} 1, \mathrm{P} 2$, "Number-2 is the staffing, you've got to have

Person/Coordinator $\mathrm{P} 3, \mathrm{P} 4$, somebody who can keep the program going." (G2P5, P6, P4)

Buy-In and $\mathrm{P} 7$

Perceptions

$\mathrm{P} 1, \mathrm{P} 2$, "There was a teacher who said this to me in my $\mathrm{P} 5$ face "You are just wasting time." (G3-P5) "My school doesn't mind that there's a garden. But they don't particularly care or place value on it." (G1-P2) 


\section{Appendix Q: Sample data from interviews, perceived benefits}

\begin{tabular}{|c|c|c|c|}
\hline Theme & Subtheme & $\mathrm{n}$ & Sample Data \\
\hline \multirow[t]{5}{*}{$\begin{array}{l}\text { Student } \\
\text { Learning }\end{array}$} & Academics & $\begin{array}{l}\text { P1, P2, } \\
\text { P3, P5, } \\
\text { P6 }\end{array}$ & $\begin{array}{l}\text { "Students out there are grasping a lot of concepts when } \\
\text { they were working outside that they were really } \\
\text { struggling with inside." (G1-P1) } \\
\text { "When I talking about the benefits of school gardens } \\
\text { I'm usually talking about the academic piece." (G2-P3) } \\
\text { "Positive results is the students are able to connect to } \\
\text { what they're doing." (G3-P5) } \\
\text { "For them it would probably be a more academic, look } \\
\text { at the lifecycle of the earth and how you maintain a field } \\
\text { that is consistently rich and we have one garden box that } \\
\text { we are leaving fallow because we want that to } \\
\text { regenerate." (G4-P6) }\end{array}$ \\
\hline & $\begin{array}{l}\text { Student } \\
\text { engagement }\end{array}$ & $\begin{array}{l}\text { P1, P2, } \\
\text { P3, P4, } \\
\text { P5, P6, } \\
\text { P7 }\end{array}$ & $\begin{array}{l}\text { "There are students in every school community for } \\
\text { whom that tactile learning, that ability to see a cause and } \\
\text { effect, comes out from the work of my own hands." } \\
\text { (G4-P6) } \\
\text { "They came back as 8th Grades in fall semester and they } \\
\text { were able to say that "We are going to grow our own } \\
\text { garden," and they actually went to plan the whole } \\
\text { seasonal... What needs to be grown. Like they gave a } \\
\text { wish list. "I want to grow basil, I want to grow this..." } \\
\text { (G3-P5) }\end{array}$ \\
\hline & $\begin{array}{l}\text { Student } \\
\text { empowerment }\end{array}$ & $\begin{array}{l}\text { P1. P2. } \\
\text { P4, P5, } \\
\text { P6, P7 }\end{array}$ & $\begin{array}{l}\text { "What a great way to get these kids, to increase their } \\
\text { student confidence within themselves, I've noticed that } \\
\text { here. Especially around gardening." (G4-P7) } \\
\text { "They prepared the beds without me saying a single } \\
\text { word. All I gave them was bags of potting soil and dark } \\
\text { soil and shovel, they prepared the beds in matter of two } \\
\text { days." (G3-P5) }\end{array}$ \\
\hline & $\begin{array}{l}\text { Environmental } \\
\text { Awareness }\end{array}$ & $\begin{array}{l}\text { P3, P6, } \\
\text { P7 }\end{array}$ & $\begin{array}{l}\text { "Schools garden impact students through environmental } \\
\text { literacy and awareness, they become more connected } \\
\text { with their environment." G2-P3) }\end{array}$ \\
\hline & $\begin{array}{l}\text { Students with } \\
\text { challenges }\end{array}$ & $\begin{array}{l}\text { P1, P2, } \\
\text { P4, P5, } \\
\text { P6, P7 }\end{array}$ & $\begin{array}{l}\text { "This is a very immediate thing that can really be a } \\
\text { gateway for some of our students, especially the ones for } \\
\text { whom school is not a successful enterprise, this is a } \\
\text { gateway." (G4-P6) }\end{array}$ \\
\hline $\begin{array}{l}\text { School } \\
\text { Culture }\end{array}$ & Pride of Place & P1, P2 & $\begin{array}{l}\text { "I actually heard a student who is a 5th grader at one of } \\
\text { our planning meetings that we invite students to before } \\
\text { we build the garden, he literally stood up in the meeting } \\
\text { and said that the thing he was most excited about was } \\
\text { that his school was finally going to have one of the nice } \\
\text { things that some of the schools in the rich part of D.C }\end{array}$ \\
\hline
\end{tabular}


had. He's 10 years old and he's like fully aware of that." (G1-P1_

School

P3, P4, "Both the garden and healthy eating and the market has

Community

P5

just like become and are important parts of the school

community and just that shapes habits, that shapes

eating, that shapes mindsets." (G2-P4)

Health Food exposure P2, P3, "For kids to know where their food is coming from to be

and $\mathrm{P} 4, \mathrm{P} 5$ able to grow their own food and to know what healthy food is, I think that like a long term impacts of that on Wellness

Willingness to P5, P6, both them and their family and communities." (G2-P4)

try new things $\mathrm{P} 7$

"My daughter came home the other day and said, "mom, I tried this great new thing that we've never tried before and it was really good, it's called pesto!"'. And the mother was going, I have put that green condiment on the table time after time, and you never wanted to try it because you said it was green and icky!" (G4-P6)

Future Health P3, P4, "Having less diet related illnesses... then appreciating P5, P6 them in later in life hopefully being healthier eaters." (G2-P3)

Social P1, P2, "All those extra benefits of just extra types of socialEmotional P3, P4 emotional learning that you don't necessarily get in a classroom." (G1-P1)

Physical P3, P4, "The garden for some of these kids who have a harder Activity P6 time with those behavior like sitting still and always staying on track like it allows them to have a break from that." (G2-P4) 


\section{Appendix R: Interview and mini focus group participant and school information}

\begin{tabular}{|c|c|c|c|c|}
\hline Panel Member Role & & Background & School Ward & School Information \\
\hline $\begin{array}{l}\text { Community partner } \\
\text { and elementary } \\
\text { school teacher }\end{array}$ & P1 & $\begin{array}{l}4 \text { years elementary } \\
\text { school teacher } \\
5 \text { years teacher } \\
\text { training }\end{array}$ & All Wards & $\begin{array}{l}\text { Not associated with a specific } \\
\text { school or ward. }\end{array}$ \\
\hline Community partner & P3 & $\begin{array}{l}4 \text { years science teacher } \\
\text { School Garden } \\
\text { Specialist }\end{array}$ & All Wards & $\begin{array}{l}\text { Not associated with a specific } \\
\text { school or ward. }\end{array}$ \\
\hline $\begin{array}{l}\text { School } \\
\text { Administration } \\
(7-8)\end{array}$ & P6 & Director of Operations & Ward 3 & $\begin{array}{l}362 \text { students - middle } \\
26 \% \text { economically } \\
\text { disadvantaged } \\
43 \%-32 \% \text { White/non-Hispanic } \\
37 \%-50 \% \text { African American }\end{array}$ \\
\hline $\begin{array}{l}\text { School Garden } \\
\text { Coordinator (SGC) } \\
\text { (PK-5) }\end{array}$ & P7 & $\begin{array}{l}13 \text { years gardening } \\
\text { experience } \\
1 \text { year at elementary } \\
\text { school }\end{array}$ & Ward 4 & $\begin{array}{l}435 \text { students } \\
13 \% \text { economically } \\
\text { disadvantaged } \\
65 \% \text { White } \\
15 \% \text { Hispanic/Latino } \\
9 \% \text { Black }\end{array}$ \\
\hline $\begin{array}{l}\text { Community partner } \\
\text { and teacher } \\
\text { (PK-5) }\end{array}$ & $\mathrm{P} 2$ & $\begin{array}{l}1 \text { year teaching } \\
\text { cooking and gardening } \\
\text { classes }\end{array}$ & Ward 5 & $\begin{array}{l}563 \text { students } \\
29.7 \% \text { economically } \\
\text { disadvantaged } \\
38.2 \% \text { Hispanic/Latino } \\
31.8 \% \text { White } \\
22 \% \text { African American }\end{array}$ \\
\hline $\begin{array}{l}\text { Classroom teacher } \\
\text { (PK-3-8) }\end{array}$ & P5 & $\begin{array}{l}2 \text { years as } \\
\text { environmental science } \\
\text { teacher }\end{array}$ & Ward 5 & $\begin{array}{l}402 \text { students } \\
60 \% \text { economically } \\
\text { disadvantaged } \\
86.8 \% \text { African American } \\
\text { 9.5\% Hispanic/Latino }\end{array}$ \\
\hline $\begin{array}{l}\text { High School } \\
\text { Garden Coordinator } \\
(9-12)\end{array}$ & P4 & $\begin{array}{l}7 \text { years gardening } \\
\text { experience } \\
3.5 \text { years SGC } \\
\text { experience }\end{array}$ & Ward 8 & $\begin{array}{l}388 \text { students } \\
60 \% \text { economically } \\
\text { disadvantaged } \\
98.1 \% \text { African American } \\
1.3 \% \text { Hispanic/Latino }\end{array}$ \\
\hline
\end{tabular}

